Portland State University

PDXScholar

$5-22-2020$

\title{
Wildlife Connectivity Modeling for the Northern Red- legged Frog in the Portland Metropolitan Area, Oregon
}

Amanda Hilary Temple

Portland State University

Follow this and additional works at: https://pdxscholar.library.pdx.edu/open_access_etds

Part of the Geography Commons

Let us know how access to this document benefits you.

Recommended Citation

Temple, Amanda Hilary, "Wildlife Connectivity Modeling for the Northern Red-legged Frog in the Portland Metropolitan Area, Oregon" (2020). Dissertations and Theses. Paper 5432.

https://doi.org/10.15760/etd.7305

This Thesis is brought to you for free and open access. It has been accepted for inclusion in Dissertations and Theses by an authorized administrator of PDXScholar. Please contact us if we can make this document more accessible: pdxscholar@pdx.edu. 
Wildlife Connectivity Modeling for the Northern Red-legged Frog in the Portland Metropolitan Area, Oregon

by

Amanda Hilary Temple

A thesis submitted in partial fulfillment of the requirements for the degree of

Master of Science

in

Geography

\section{Thesis Committee:}

Martin Lafrenz, Chair

Catherine de Rivera

Geoffrey Duh

Portland State University

2020 
C 2020 Amanda Hilary Temple 


\begin{abstract}
Effective habitat connectivity tools that use GIS data perform well in remote areas but may not be as dependable in urban environments. My goal was to study uses and limitations of a conservation management tool in development, the Metro Regional Habitat Connectivity Toolkit, which evaluates connectivity for and permeability of wildlife movement. Habitat quality scores are generated from GIS-derived and field collected data such as connectivity patch/matrix characteristics, water source, vegetation, other structural components, wildlife observations, and human disturbance at survey sites. I compared GIS and field generated habitat quality scores for the Northern Redlegged Frog (Rana aurora) in urbanizing Gresham East Buttes, Oregon. Using Spearman's ranked correlation, there was low positive correlation between GIS and field scores indicating the two scores assess different types of data. The magnitude of difference between these scores had no interdependence along a development gradient. Assessment of Northern Red-legged Frog locations in Forest Park, resulted in habitat quality scores which were sensitive to the presence or visibility of water sources and other structural components such as woody debris. These findings indicate the need for repeat field surveys, and the importance of field-collected data's unique contributions which ensure crucial wildlife dispersal is protected in rapidly changing environments. To give regional conservation managers confidence in applying connectivity tools in urbanizing environments, I compared a predictive Circuitscape connectivity model to additional field collected data such as habitat quality, and distance between aquatic-
\end{abstract}


terrestrial habitats using aquatic egg mass surveys for Northern Red-legged Frog. Further genetic and demographic studies are recommended to fully discern the implications of these findings and to protect this Oregon state strategy species that utilizes at-risk aquatic and terrestrial connections during its annual migrations. 


\section{Acknowledgements}

Research support, encouragement, and countless feedback from faculty

Martin Lafrenz, Catherine de Rivera, Leslie Bliss-Ketchum, Geoffrey Duh, David Banis

Field surveying, data entry, or radio-telemetry monitoring assistance from

Jesse, Lita, Alex, Jim, Amber, Jeffrey, Brian, Sara, Corrine and additional volunteers

Permitting and site access from

Harborton Frog Shuttle, PSU-IACUC, Oregon Department of Fish and Wildlife, City of Portland Department of Parks and Recreation-Forest Park, City of Gresham, Nolan J.

Additional feedback and correspondence from all the frog fans out there

Katie H., Lauren C., Laura G., Sue. B., Lori H., Meghan G., Katie W., Marc H., Kelly L., Elke W., Lisa H., Jakob D.

Funding from

Metro Regional Government, Bullitt Foundation, Oregon Wildlife Foundation

Portland State University

Larry and Nancy Price Field Work Grant

William and Edith Rockie Scholarship

Thank you to my family and loved ones for supporting me 
Table of Contents

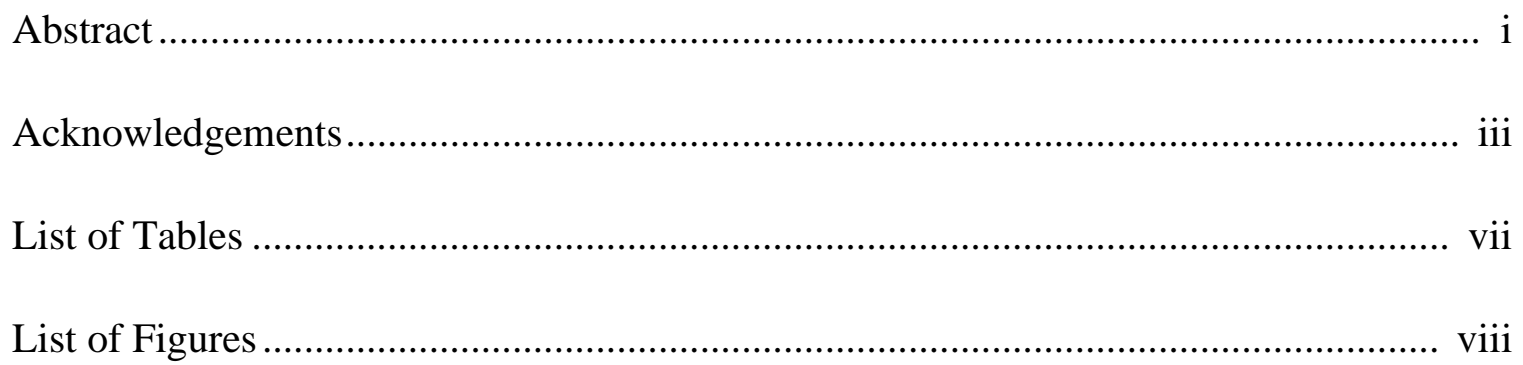

* Chapter 1

Connectivity Literature Review and Tool Development

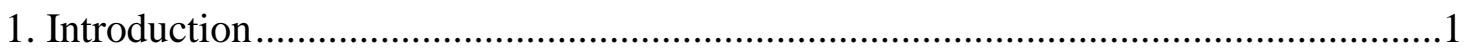

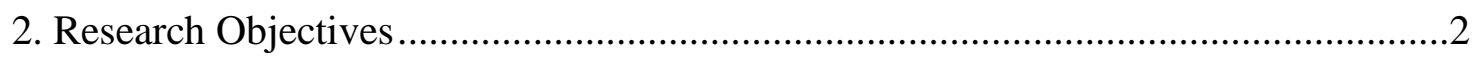

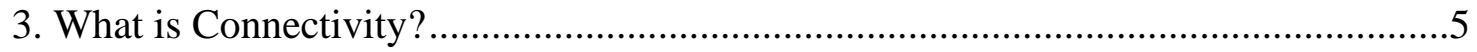

4. Regional Connectivity Strategies.......................................................................

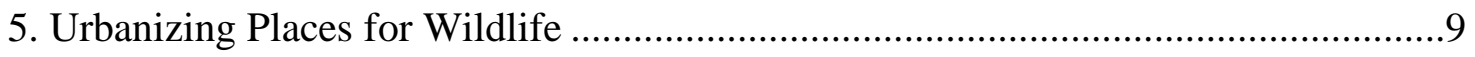

6. Connectivity Modeling Tools ............................................................................11

7. Metro Regional Habitat Connectivity Toolkit Development.................................13

* Chapter 2

Evaluation of Metro Toolkit Habitat Quality Scorecard:

Case Study Northern Red-legged Frog (Rana aurora)

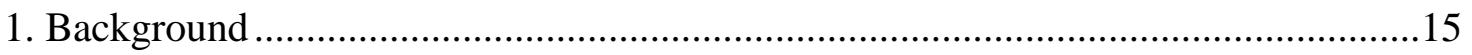

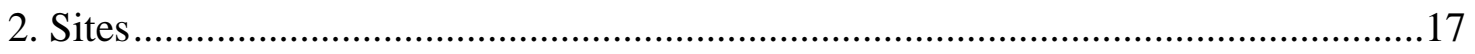

3. Methods

3.1 Habitat Connectivity Zones ..................................................................21

3.2 GIS and Field Data Collection .....................................................................25

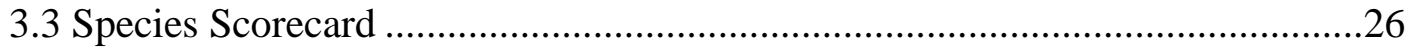


3.4 Comparison between GIS and Field Scores................................................27

4. Results

4.1 GIS and Field Data Habitat Quality Score..................................................28

4.2 Differences Between GIS and Field Scores Along Development Gradient ......29

5. Discussion .32

Chapter 3

Sensitivity Analysis in the Field:

Case Study Northern Red-legged Frog (Rana aurora)

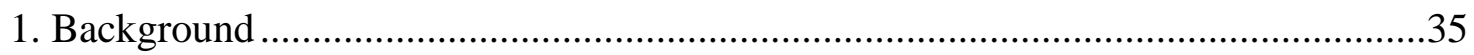

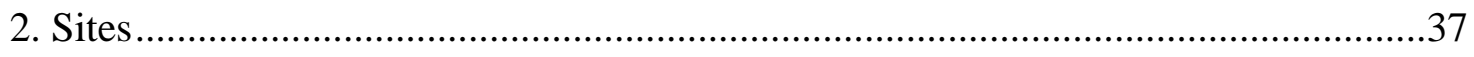

3. Methods

3.1 Forest Park Survey Sites ..................................................................... 41

3.2 Scorecard Sensitivity of Field Collected Habitat Characteristics .....................41

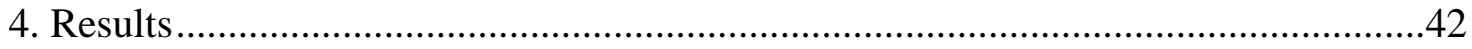

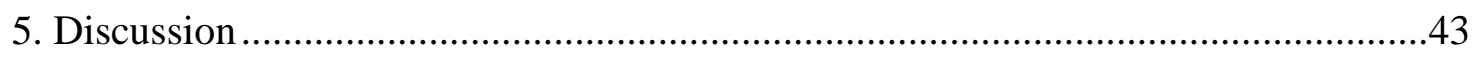

Chapter 4

Applications of Metro Regional Habitat Connectivity Toolkit for Conservation Managers: Case Study Northern Red-legged Frog (Rana aurora)

1. Background

1.1 Need for Northern Red-legged Frog Connectivity Tools .45

1.2 Circuitscape Uses and Limitations......................................................48

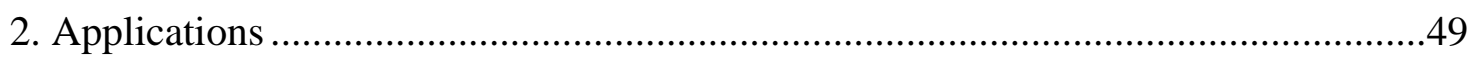




\section{- Chapter 5}

Conclusions and Future Research Recommendations

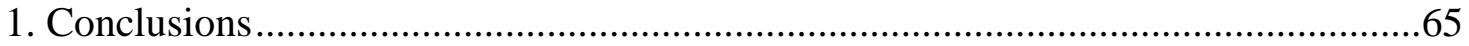

2. Future Research Recommendations

2.1 Monitoring Amphibian Habitat and Movement ..........................................66

2.2 Urban Habitat Connectivity Management ..................................................69

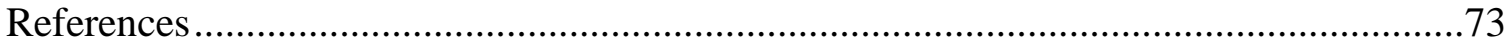

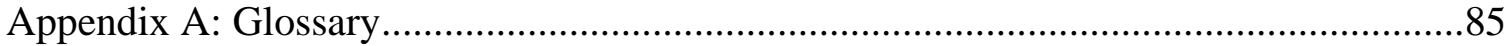

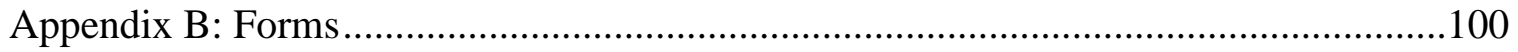

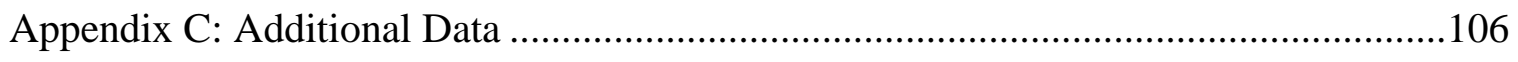

Appendix D: Forest Park Radio-telemetry Data .......................................................113 
List of Tables

Table 1. Thesis Research Objectives ................................................................

Table 2. Urban Habitat Connectivity Management .................................................52

Table 3. Priority Connectivity in Gresham East Buttes, Oregon ...................................62 
List of Figures

Figure 1. Gresham East Buttes Study Site, Gresham, Oregon..........................................18

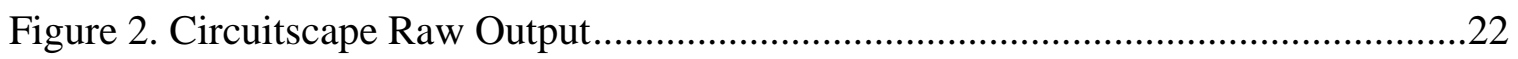

Figure 3. Habitat Connectivity Zones in Gresham East Buttes, Oregon ............................24

Figure 4. Habitat Connectivity Zone Close-Up along Johnson Creek, Oregon..................25

Figure 5. Spearman's Ranked Correlation Coefficient Results in Gresham East Buttes, Oregon .................................................................29

Figure 6. Percent Development in the Gresham East Buttes, Oregon .................................30

Figure 7. Comparison Between GIS and Field Habitat Quality Score in Gresham East Buttes, Oregon ........................................................................ 31

Figure 8. Forest Park Study Site, Linnton, Oregon............................................................39

Figure 9. Scorecard Sensitivity of Field-verified Habitat Characteristics Collected in 2019, Forest Park, Oregon ............................................................4

Figure 10. Connectivity Pathway Delineation in Gresham East Buttes, Oregon ...............51

Figure 11. Criteria 1: Circuitscape Connectivity Model.....................................................54

Figure 12. Criteria 2: Metro Toolkit Habitat Quality Score ...........................................55

Figure 13. Criteria 3: Aquatic and Terrestrial Habitat.................................................59 


\section{Chapter 1}

Connectivity Literature Review and Tool Development

\section{Introduction}

Habitat connectivity conservation applies to a variety of wildlife, geographies, and ecosystem functions. This form of conservation management targets the preservation and enhancement of habitat in wildlife movement corridors, by connecting diverse habitats, boosting resilience in natural systems, identifying hazards to wildlife, providing protected spaces, and supporting environmental services like watershed health. The need for urban habitat connectivity in the Portland Metropolitan region was identified by U.S. Fish and Wildlife Service, Portland Metro Regional Government, the City of Portland 2035 comprehensive plan, and by the City of Gresham watershed and land use plans (USFWS Willamette Valley Conservation Study 2017, Metro Regional Framework Plan 2011, Metro Urban Growth Management Functional Plan 2018, Metro Parks and Nature Annual Report 2017-2018, City of Portland 2018 Policy 3.64,3.65,3.66, City of Gresham Water Quality Manual 2003, City of Gresham Johnson Creek Stormwater Master Plan 2005, Metro \& city of Gresham Gabbert Butte Master Plan 2019). A proactive approach to maintaining habitat connectivity is critical to enable wild species to maintain populations in and around this increasingly urban environment. In response to this need Portland State University researchers developed the Metro Regional Habitat Connectivity Toolkit which incorporates both GIS and field-collected data. This tool is for conservation managers to generate species-specific habitat scores for 500 x 500 meter habitat connectivity zones and to evaluate connectivity in terms of species-specific 
movement permeability in urban locations. As part of updating and refining the toolkit, I evaluated one aspect of species scoring with the toolkit and used scoring results to evaluate connectivity in my study area.

\section{Research Objectives}

The goal of this study was to test uses and limitations of novel field tools which evaluate and map regional connectivity in urbanizing places like the Portland metropolitan region (Table 1). Unlike tools which only use GIS data to model wildlife movement, analytical tools like the Metro Regional Habitat Connectivity Toolkit also incorporates field-collected data to score habitat quality and evaluate connectivity for surrogate species in fragmented and rapidly changing environments. The first chapter of this document consists of a connectivity literature review and a discussion on tools used for connectivity modeling. This covers the concept of connectivity, urban wildlife needs, connectivity tools, development of the Metro toolkit, and background information on the case-study species for chapters two through four, the Northern Red-legged Frog (Rana aurora). In chapter two I compared GIS and field collected habitat characteristics to determine if each data type contributed unique information about functional habitat in an urbanizing environment. In chapter three I tested sensitivity of habitat characteristics in a natural environment using radio-telemetry tracked frogs to determine the limitations of field-collected data. Chapter four applies the Metro Toolkit and provides conservation managers with an example for mapping priority connectivity pathways in urbanizing environments. I use multiple tools such as the connectivity modeling tool Circuitscape, 
habitat-permeability field assessments from the Metro Toolkit, and locally surveyed egg

mass survey data to support additional connectivity tool development. Chapter five

concludes with future tool development using field-based habitat connectivity monitoring

and additional GIS connectivity modeling applications.

\section{Table 1. Thesis Research Objectives}

Summary of the research questions and discussion points which address the research objective: To test uses and limitations of novel field tools that evaluate and map regional connectivity in the Portland metropolitan region. Chapter one is a literature review on connectivity and tool development for the Metro Regional Connectivity Toolkit. Chapter two and three use the Northern Red-Legged Frog (Rana aurora) as a case study for connectivity tool development and applications. Chapter two compares GIS and field data derived habitat quality scores for a species-specific case study, the Northern Red-legged Frog, in an urbanizing environment. Chapter three evaluates the sensitivity of habitat characteristics collected in a natural, forested environment. Chapter four is an application of connectivity tools to map Northern Red-legged frog connectivity in the urbanizing Gresham East Buttes area. Highest priority pathways were identified using a combination a Circuitscape connectivity model, Metro Regional Habitat Connectivity Toolkit, and other GIS data such as known aquatic breeding sites. Chapter five concludes with future connectivity monitoring and modeling.

\section{Research Goal: To test uses and limitations of novel field tools} which evaluate and map regional connectivity in urbanizing environments.

\begin{tabular}{|c|c|}
\hline $\begin{array}{c}\text { Chapter 1 } \\
\text { Connectivity Literature Review and } \\
\text { Tool Development }\end{array}$ & Objectives \\
\hline $\begin{array}{l}\text { How is the development of regional } \\
\text { connectivity conservation management } \\
\text { tools a novel approach to evaluate habitat } \\
\text { connectivity for wildlife moving in the } \\
\text { Portland Metropolitan region? }\end{array}$ & - $\begin{array}{l}\text { Summarize connectivity, urban } \\
\text { environments, and the development of the } \\
\text { Metro Toolkit }\end{array}$ \\
\hline $\begin{array}{c}\text { Chapter 2 } \\
\text { Evaluation of Metro Toolkit } \\
\text { Habitat Scorecard } \\
\text { (Case Study Question 1) }\end{array}$ \\
\hline
\end{tabular}




\begin{tabular}{|c|c|}
\hline $\begin{array}{l}\text { Q1: How do GIS derived, and field } \\
\text { collected data compare in terms of habitat } \\
\text { quality score generated by quantitative } \\
\text { scoring tools like the Metro Toolkit? } \\
\text { (Case study: Northern Red-legged Frog } \\
\text { in the urbanizing Gresham East Buttes, } \\
\text { Oregon) }\end{array}$ & $\begin{array}{l}\text { - Use the Metro Toolkit habitat quality } \\
\text { assessment and interpret scorecard } \\
\text { - Derive Habitat Quality scores from GIS } \\
\text { data and field collected data, determine if } \\
\text { they are significantly correlated } \\
\text { - Discuss whether there was a difference } \\
\text { between GIS and field scores along a } \\
\text { development gradient (low to high urban } \\
\text { and agriculture). }\end{array}$ \\
\hline $\begin{array}{c}\text { Chapter } 3 \\
\text { Sensitivity Analysis in the Field } \\
\text { (Case Study Question 2) }\end{array}$ & Objectives \\
\hline $\begin{array}{l}\text { Q2: Which habitat characteristics are } \\
\text { sensitive to field survey methods and can } \\
\text { potentially influence habitat quality } \\
\text { scores generated from managed, intact } \\
\text { forest habitats? (case study: Northern } \\
\text { Red-legged Frog in Forest Park, Oregon) }\end{array}$ & $\begin{array}{l}\text { Describe habitat characteristics such as } \\
\text { water source and other structural } \\
\text { components which influence habitat } \\
\text { quality scores obtained at known } \\
\text { locations of Northern red-legged Frog in } \\
\text { Forest Park using location data. }\end{array}$ \\
\hline $\begin{array}{c}\text { Chapter } 4 \\
\text { Applications of Metro Toolkit for connectivity } \\
\text { conservation managers }\end{array}$ & Objectives \\
\hline $\begin{array}{l}\text { - How can conservation managers apply } \\
\text { regional connectivity tools to evaluate } \\
\text { and map priority connectivity for the } \\
\text { Northern Red-legged frog? }\end{array}$ & $\begin{array}{l}\text { - Identify priority connectivity pathways } \\
\text { for } R \text {. aurora in Gresham East Buttes } \\
\text { using suggested criteria. } \\
\text { - Discuss potential management. }\end{array}$ \\
\hline $\begin{array}{l}\text { Chapter } 5 \\
\text { Conclusion }\end{array}$ & Objectives \\
\hline $\begin{array}{l}\text { - Final thoughts and recommendations } \\
\text { - Future research }\end{array}$ & $\begin{array}{l}\text { Discuss future habitat connectivity } \\
\text { monitoring and GIS connectivity } \\
\text { modeling }\end{array}$ \\
\hline
\end{tabular}


3. What is Connectivity?

Connectivity mitigates loss of species and biodiversity, which is considered a major threat to global wildlife conservation. The term connectivity applies to conservation design and wildlife management strategies that reduce habitat fragmentation and restore movement. Connectivity takes on many sub-categories which include landscape connectivity, habitat connectivity, ecological or abiotic connectivity and ecosocial connectivity (Fischer and Lindenmayer 2007; Mitchell, Bennett, and Gonzalez 2013). Connectivity goals can and should incorporate a broad scope of infrastructure development, forestry management, ecosystem services, health, transportation, and energy which increased access of resources to people (Anderson et al. 2016).

Habitat connectivity is of particular importance to wildlife because it functions at a local scale to support individuals, metapopulations, or communities by linking habitat patches with permeable areas in order to facilitate dispersal movement and wildlife survival. It targets the ability of organisms and/or their genetic material to move among their populations and potential habitats. This further diverges into two categories, structural, and functional connectivity components. The structural components are quantifiable and is stored as spatial data, i.e. percent impervious surfaces, or vegetation density. Restoration corridors and reserve designs rely on structural parameters such as minimum patch size, fragmentation, edge effect, distance, quality or age of habitat to define the connectivity of the landscape (Soule 1991; Campbell 2000; Fahrig 2003; Fischer and Lindenmayer 2007; Downs and Horner 2012). One caveat of this approach is the single linkage corridors designed around specific structural parameters do not always 
consider the wide range of species movement behaviors, or the influence of anthropogenic conditions on connectivity (Angold et al. 2006; Naidoo et al. 2018). The functional component is included as an important addition to connectivity design because it encompasses site-specific conditions and habitat resources that cannot necessarily be modeled with GIS (Fischer and Lindenmayer 2007).

By promoting connected habitat we introduce options for wildlife to circumvent barriers and minimize negative edge effects especially in places lacking high quality natural spaces (Lindenmayer et al. 2008). Species' reduction in time and energy needed to reach food sources, shelter, and metapopulations can improve survival in the face of long-term land use and climate change (Schwartz 1999; Fischer and Lindenmayer 2007; Hannah et al. 2014). Habitat connectivity can mitigate disruptions to gene-flow, balance source- sink metapopulations, and reduce the chance for extinction vortices (Hanski 1998). Managed environments like cities, have highly fragmented, small patches of habitat and contain strong barriers that can impede wildlife movement. Therefore, urbanizing places require long-term conservation goals to minimize isolation of populations and reduce competition for resources (Soule 1991). As land use changes continue to transform floodplains, wetlands and forest environments in the Pacific Northwest, an extensive network of connectivity and the right tools are needed to preserve functional habitat connectivity requirements (McRae et al. 2016; Metro- Parks and Nature System Plan 2016). 


\section{Regional Connectivity Strategies}

Like many developed regions, land use change in the lower Willamette Valley has fundamentally altered what was once a highly connected landscape. Hence, there is a need to increase connectivity through management. Connectivity strategies can benefit both conservation and development by providing creative solutions for multiple species and human-wildlife conflicts. In the past, many connectivity goals centered on threatened and endangered species. These site-specific restorative strategies included the use of migration corridors, translocation of animals, breeding programs, road crossings, and the establishment of riparian and wetland buffers. The focus for connectivity had often been large on charismatic and key-stone species like black bears or cougars. The issue with single species connectivity is that different species' functional habitat requirements are dependent on access, availability of habitat, and anthropogenic disturbances. There are uncertainties in how designed species corridors may unintentionally introduce edge effect or reduce permeability to better habitat for other species in the area (King et al. 2009). Additionally, some animals have small populations requiring large home ranges while others have large populations and require multiple habitat patch types that function at certain life-stages (Hamer and Mcdonnell 2008; Poor et al. 2012; Walpole et al. 2012;

Clark et al. 2015; Naidoo et al. 2018). The limitations of single-species connectivity maps were poorly understood until conservation practices turned to strategies identifying priority and at-risk species representing communities or ecoregions rather than individuals. 
The concept of regional scale varies with respect to the species being studied, and is dependent on its home range habitat needs, individual migration distances, and population dispersal capabilities (Clark et al. 2015; Naidoo et al. 2018). However, regions are primarily defined from a management perspective especially, and the scope of this research is based on the urbanizing Portland metropolitan jurisdictional area (Beier et al. 2011; Pelletier et al. 2014). A scale-up approach is selected to represent multiple species conservation needs. For example, an approach in which surrogate species utilizing the region's more common habitats, landscape features, or movement behaviors are specially selected to represent conservation priorities. This approach strengthens underfunded research or resource-intensive conservation projects that benefit from shared funds and collaborative management plans. By merging both species-specific and jurisdictional concepts of regional connectivity, we can consider how already utilized habitat may be best protected with shared resources rather than create new connections which may have negative consequences not yet understood, i.e. disease transmission or environmental justice issues (Evans 2007; Haddad et al. 2014). Broader ecoregional scale connectivity policies may be suited for long-distance wildlife migrations, leveraged by pooled funds, with shared goals across agencies and stakeholder representation (The Pinal County Wildlife Connectivity Assessment: Report on Stakeholder Input 2013; Anderson et al. 2016). Ultimately, connectivity implementation goes beyond the regional scale to engage people and wildlife needs across property lines, state boundaries, and multi-national landscapes (Proctor et al. 2015). By testing connectivity tools in our region, we can learn 
about the gaps and limitations of applying these conservation strategies broadly and at different scales of management.

\section{Urbanizing Places for Wildlife}

In North America, developed land grew at a rate of 3.31\% from 1970 to the early 2000s. When we consider $80 \%$ of the North American human population lives in urban areas, and $80 \%$ of these cities are coastal, the impacts have been great over a short 30 year period (Gómez-Baggethun et al. 2013). The region of interest in this study, the Portland Metropolitan area, is predicted to add an additional 1.8 to 2 million people between 2015- 2035 (Metro- 2014 Urban Growth Report Investing in our communities 2015-2035). This urban shift demands increased development, housing units, and resources.

The impact of modified landscapes makes an interesting case for conserving wildlife connectivity and movement. Urban environments require exploratory management strategies for connectivity. They offer contrasting spaces and structures in close proximity with high impacts toward stakeholders (Evans 2007, Beller et al. 2019). Cities additionally have a cultural history of urban-rural movement, economic investment, and socio-political contrasts which can shift environmental priorities. Urban places can be difficult to select for connectivity conservation as there may be few sites that have high quality habitat for wildlife, low restoration management costs, multiagency engagement, and recreation or investment opportunities for residents (McRae et al. 2012). Urban spaces are constrained spatially and financially when compared to 
reserves or parks due to the complex mix of land uses and stakeholders. However, even small sized potential reserves can be established in urban areas to protect remnant habitat patches which may contain rare or threatened species (Schwartz 1999). Early urban connectivity, particularly corridor design, was viewed as "mitigation banking" to set aside land for public investment and environmental acceptance in urban places (Soule 1991). The issue with these early designs is how they isolated green spaces and did not serve multiple functional wildlife requirements and movement across cities (Evans et al. 2012; Haddad et al. 2014; Beninde, Veith, and Hochkirch 2015).

Regional planning strategies include goals for preserving natural resources through efficient land use or redevelopment on urban reserves set along the urban growth boundary. However, human-wildlife conflicts and risks to wildlife connectivity remain present, marking the need for regional connectivity research. Studies have found urban specific effects such as human influence, habitat fragmentation, roads, impervious surfaces, water use, agriculture, vertical structures, heat-island effect, and local yard scaping can affect wildlife assemblages and ecosystem services (Fernández-Juricic and Jokimäki 2001; Walsh et al. 2005; Angold et al. 2006; Bliss-Ketchum et al. 2016). With these examples, it is uncertain whether wildlife benefit from the urban planning framework, but connectivity tools can support conservation in novel landscapes by reconnecting remnant habitat patches in a way that maximizes connectivity (Standish, Hobbs, and Miller 2013; Hobbs et al. 2014).

On the positive end of urbanization, urban areas are places where multiple agencies, policies, and ecosystem services can merge under shared funds and resources. 
Urban planning goals like climate resilience, transportation, and renewable energy projects share land cover and species movements that should be informed by connectivity research. Public parks, recreation and environmental agencies also play an important role in monitoring wildlife connectivity and educating the public. Urbanizing areas are important for connectivity conservation. Inner cities are more biodiverse than previously determined. Inter-regionally cities share common generalist species, but within regions they contain unique species assemblages and communities that may provide novel refugia and genetic sources for recolonization outside of the urban area (Angold et al. 2006; Beninde, Veith, and Hochkirch 2015). Across the globe, developed features such as grassy lots, agricultural fields, water fountains, narrow greenways, and riparian corridors have supported wildlife in a number of ways (Holzer et al. 2017). Even minimal or low quality water sources and vegetation are utilized by wildlife when there are few quality options available. Features like brush piles, construction materials, agricultural areas, and ponds that appear during development can serve as transitioning habitat for urban wildlife. As tax lots are split and boundaries reworked in the urban landscape, the establishment of walls, fences, and water channels may alter the movement behavior of wildlife who already use the area for seasonal migration altering and possibly creating new migration pathways with better options.

\section{Connectivity Modeling Tools}

Connectivity models fall into two main categories, broad scale $>100 \mathrm{~m}$ resolution, or fine scale $<30 \mathrm{~m}$ resolution maps (Beier et al. 2011). Either process-based or analytical 
methods are used to produce connectivity models. Connectivity modeling tools like Linkage Mapper, Circuitscape, and other GIS processing tools identify connective areas that are important for both land management goals and wildlife movement (Spear et al. 2010). These tools transform remotely sensed and collected data to continuous environmental variables that best represent species habitat suitability or occurrence probability (Poor et al. 2012). Process-based connectivity tools like those that use genetics, occupancy, or maximum entropy (presence-only), rely on up to date, fieldverified environmental parameters and expert knowledge on multivariate landscape resistances to train model predictions (Walpole et al. 2012; Bond et al. 2017; Zeller et al. 2018). The accuracy of process-based models depends on the existing availability and coverage of recent land cover data at conservation-appropriate scales (Schwartz 1999; Gomez-Rodriguez et al. 2008). Site-scale field validation can be time consuming and costly for regional scale connectivity management, which is why GIS methods to identify core habitat areas, gaps, and barriers were developed to assess connectivity (Porej, Micacchion, and Hetherington 2004; Spear et al. 2010; McRae et al. 2012; Wu, Lane, and Liu 2014; Harris et al. 2017; Faccio, MacFaden, and Buford 2019).

In response to regional connectivity management needs, analytical modeling tools were also developed to encourage land managers to implement connectivity strategies on the ground using resources available to validate functional connectivity needs for multiple species (Spencer et al. 2010; Koen et al. 2014). These analytical tools integrate information such as state agency goals, focal species selections, climate data, land use, and resiliency-based strategies to support connectivity management (Spencer et al. 2010; 
Nunez et al. 2013; McRae et al. 2016; Drake, Griffis-Kyle, and McIntyre 2017; Keeley et al. 2018). One major benefit of the analytical or combined approaches is the ability to create a priori, multi-purpose maps that represent functional habitat connectivity serving a wide range of management goals as more information is added or validated (Koen et al. 2014; McRae et al. 2016). These analytical tools are limited by funding and resources to produce field-validated regional datasets needed to model fine-scale connectivity, such as long-distance ungulate migrations, and seasonal windows of time for amphibian and reptile migrations (Alford and Rowley 2007; Poor et al. 2012; Mondal et al. 2016; McMahon et al. 2017).

\section{Metro Regional Habitat Connectivity Toolkit Development}

The Portland metropolitan region was identified as having potential threats to wildlife species due to land use change and developments (U.S. Fish and Wildlife 2017). Conservation objectives in the Willamette Valley specifically identified sensitive habitats and wildlife species requiring conservation management plans. A voter approved parks and natural areas levy passed for the Portland Metropolitan region in 2013, which expanded funding to restoration, maintenance, and community access projects for fish and wildlife habitat, parks and natural areas in the region (Metro- Parks and Nature System Plan 2016). These designations heightened the need for habitat connectivity tools to support regional conservation goals. Identifying and acquiring habitat conservation zones has played a large part in the metropolitan region's strategic urban growth, especially along the urban growth boundary. Regional objectives have included 
maintaining connectivity between riparian corridors and upland wildlife habitat and expanding preservation of contiguous habitat particularly for areas containing low shrub, wetland and associated riparian patches. Additionally, riparian and vegetated areas within conservation zones were designated to protect fish and wildlife passage. Restoration and mitigation actions were implemented to retain ecological function of habitats alongside development in the region (Metro- 2014 Urban Growth Report Investing in our communities 2015-2035).

The Metro Regional Habitat Connectivity Toolkit (Metro Toolkit) was created as an expert-based approach which uses both GIS and field assessment methods to parameterize and weight characteristics that influence wildlife movement. The influence of physical changes like urbanization and indirect influences of anthropogenic disturbances like light or noise pollution, is integrated into surrogate species scorecards which are region-specific assessments that generate quantitative habitat and permeability quality scores. The focus of the Metro Toolkit within the scope of this research is to apply novel connectivity management tools for urban-adapted, aquatic-terrestrial dependent species like $R$. aurora. Rana aurora, a surrogate species which represents a larger group of wildlife that require connectivity between aquatic and terrestrial habitats to survive. Its specific habitat, wetlands and forested environments, were also identified as a priority habitat for the Portland Metropolitan region. 


\author{
Chapter 2 \\ Evaluation of Metro Toolkit Habitat Quality Scorecard: \\ Case Study Northern Red-legged Frog (Rana aurora)
}

\title{
1. Background
}

Habitat suitability and connectivity tools were developed for land management, conservation strategies, and field surveying assistance to assess habitat quality and potential to protect or maintain survival for wildlife species in natural environments. However, many habitat assessment tools were not developed to specifically represent urban wildlife and urban management needs (Standish, Hobbs, and Miller 2013; Hobbs et al. 2014). Connectivity management tools like the Metro Regional Habitat Connectivity Toolkit are currently in development to collect information and generate quantitative scores for species-specific movement permeability and functional habitat in heterogenous landscapes with rapidly changing environments (PSU-Metro. In Progress).

The goal of this chapter is to evaluate habitat assessment and quantitative scoring methods which were developed from regional species expert feedback and literature review. The purpose of this evaluation is to determine whether GIS and field-based data collection and scoring methods are comparable and contribute unique information to connectivity conservation management. I used a case-study, the terrestrially migrating Northern Red-legged Frog (Rana aurora), which was selected as one of the surrogate species representing aquatic-terrestrial connectivity in the Portland Metropolitan region (Bliss-Ketchum et al. In Progress). I evaluated this species' scorecard which ranks habitat quality at survey sites developed specifically for the region. By comparing GIS and field 
habitat quality scores collected for the Metro Toolkit in an urbanizing environment, I will discuss the potential limitations of analytical, expert-based connectivity tools similar to this one.

Q1: How do GIS derived, and field collected data compare in terms of a habitat quality score generated by quantitative scoring tools like the Metro Toolkit?

I used the case study of the Northern Red-legged Frogs (Rana aurora) to answer this question aimed at estimating the ability of wildlife to pass through habitat in urbanizing environments. To determine whether GIS-based versus field-based data represent different information and varied in their scores, I compared habitat characterization by these two data types. I compared GIS and field data collected for the Gresham East Buttes using correlation between these two data types. Although field verification is considered expensive and time consuming its inclusion in the Metro Toolkit was intended to generate and quantify more accurate results than GIS data alone, which I further assessed with this work (Rogers 2017). Tools that quantify anthropogenic influences on the changing landscape especially on the fringes of urban areas are needed for connectivity conservation research (Lapoint et al. 2015). Field-collected habitat quality scores should ideally capture information on species movement behaviors, seasonal migrations, breeding or nesting requirements, ecological processes, and connectivity in urbanizing places. 
2. Sites

The East Buttes study area is located in the southwestern corner of the City of Gresham, on the southern edge of Multnomah County, and the eastern edge of the Metropolitan urban growth boundary (Figure 1). This $\sim 44$ square kilometer study area is approximately $66 \%$ developed, primarily suburban residential (>50\%) and agriculture (<20\%) (PSU-INR Oregon State Habitat Map 2018). The site contains part of the Boring lava field, a chain of extinct cinder cones that have since become forested buttes and public parks/natural areas. The study extent contains four anchor-point buttes within the City of Gresham /Multnomah County boundary. These are Gabbert Butte, Hogan Butte, Gresham Butte, and Jenne Butte. Towle and Sunshine Butte are also within the southern reaches of the study area but were not set as connectivity anchor points because of their proximity to the Clackamas County boundary line where different management and monitoring strategies have been implemented. 


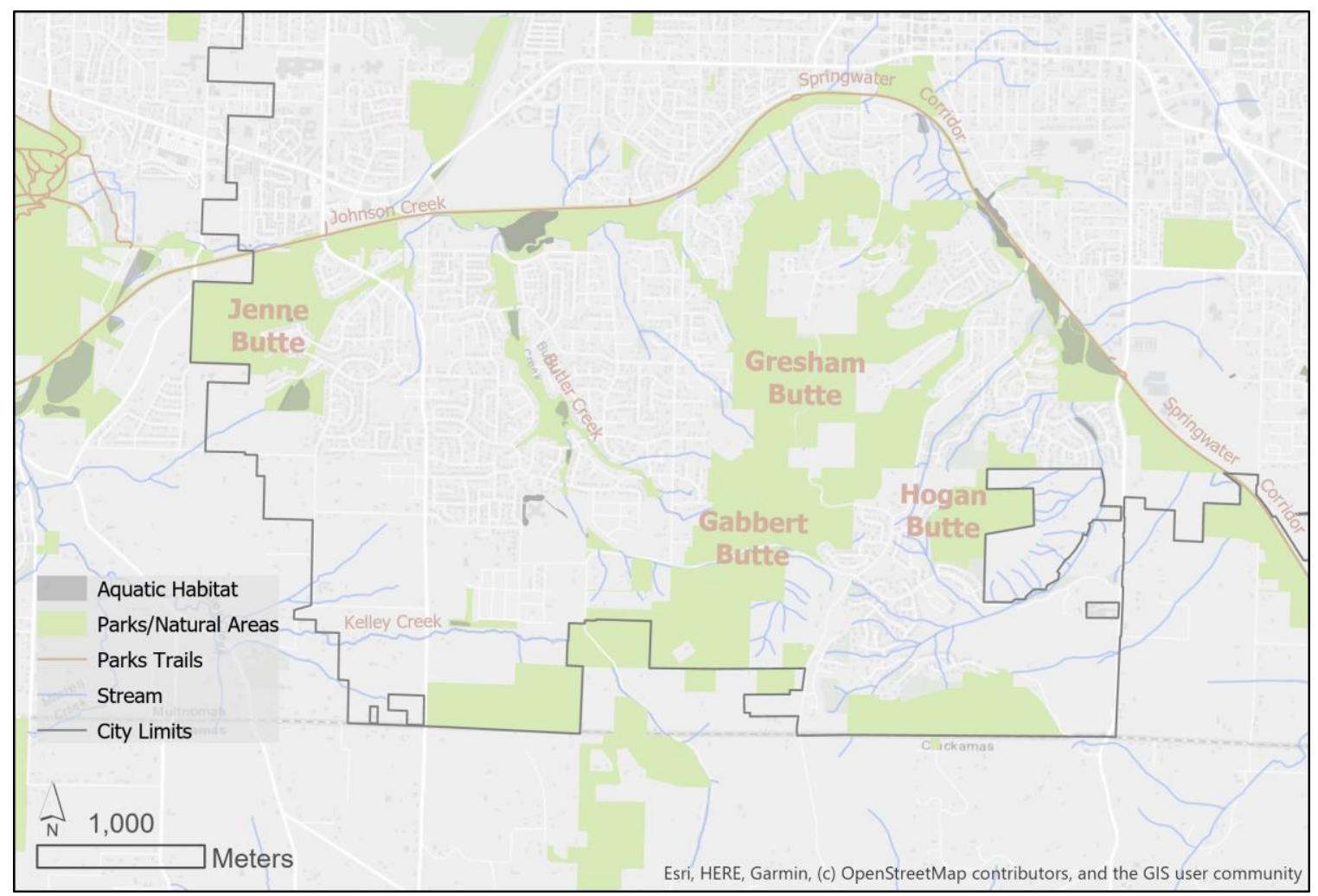

Figure 1. Gresham East Buttes Study Site, Gresham, Oregon

Gresham East Buttes area containing four buttes with a variety of developed lands and rapidly urbanizing areas. (Datum: GCS_North_American_1983, Projection: NAD83 UTM Zone 10N, Extent:* West longitude $-122.498315 *$ East longitude $-122.396333 *$ North latitude $45.502255 *$ South latitude 45.451742). Housing developments, industry, wetlands, riparian areas, agriculture, trail systems, and parks can all be found here. Amphibian monitoring in the area was conducted frequently between 2006-2015.

Between the $19^{\text {th }}-20^{\text {th }}$ century, the primary management in this area was timber harvesting and agricultural conversion (Murphy 2009). The north-western section of the East Buttes currently has a mix of agricultural fields, pastures, and mixed-use development. Development appears as a patchwork landscape consisting of multi and single-family urban-suburban neighborhoods. Regional agencies like Metro, City of Gresham parks and stormwater divisions currently manage this area. The Springwater corridor bike and pedestrian trail, private horse farms, golf courses, recreation areas, and 
scattered industrial or commercial lands are also present. Interjurisdictional, urbanizing streams are also located in this region that drain to Johnson Creek and provide numerous sites for amphibian habitat. Additionally, many publicly owned spaces are undergoing riparian, wetlands, wet prairie, and oak savanna restoration. Habitat restoration is done by removing impervious surfaces from industrial lands and by planting native species. The presence of human activity, declining plant and wildlife species in the Willamette valley garners connectivity assessment and management attention (Dobson and Gilroy 2009; Christy and Alverson 2011). Metro Regional Government which has jurisdiction over parts of the East Buttes, has acquired land east of Interstate 205 and south of Powell Boulevard to maintain wildlife habitat and natural areas. In 2014, Metro then created the East Buttes Site Conservation plan (SCP) to manage habitat and conserve priority areas, in particular the plan focuses on natural areas classified as habitat preserves south of the more urbanized areas of the East Buttes (Gabbert Butte Nature Park Master Plan 2019). An extensive system of public trails is also managed by City of Gresham between buttes along the Gresham Buttes Saddle Trail as well as along Butler Creek and Johnson Creek. Several of these buttes are already connected and new trail systems have been underway in Hogan Butte Nature Park and in the proposed master plan for Gabbert Butte Nature Park.

The long-term amphibian egg mass surveys, urban biodiversity recovery, and stormwater management actions makes the Gresham East Buttes a site of interest for $R$. aurora across multiple agencies. The East Buttes are a target site for connectivity not only because it is undergoing rapid urbanization and is on the fringes of its urban growth 
boundary, but also because it contains numerous priority sites, where much of $R$. aurora's egg masses have been observed on the western and eastern portions of Johnson Creek watershed. Most water bodies in the East Buttes area are managed by the Johnson Creek Watershed Council and include a number of stormwater ponds, and off-channel ponds that are used by amphibians. The few perennial ponds in this region are located on Kelly Creek and Butler Creek. Just outside of the study area, to the West, Powell Butte hosts several breeding sites accessible to frogs which are monitored by the City of Portland.

The buttes have limited numbers of ponds adjacent to upland habitat. Typically, artificial stormwater ponds or restored wetlands are utilized by frogs and are often connected by vegetated tributaries. Salmon habitat restoration has inadvertently removed slow moving, vegetated waters critical for aquatic amphibian habitat (Personal correspondence with K. Holzer, City of Gresham). Rana aurora are more often found breeding in ephemeral ponds as little as 0.3 meters deep (June), that have presence of aquatic vegetation without fish. Older ponds have been recently filled on Hogan Butte, while ponds are created in new housing developments. Many of these stormwater ponds are only dredged every five years for cleaning typically in summer and outside the frog's breeding season. The establishment of $R$. aurora at these ponds occurs after chorus frog establishment, within two to five years after management and once aquatic vegetation is available in the pond. If these management actions remain stable in the coming years, then connectivity can be integrated as the next step for $R$. aurora conservation in the area. 
3. Methods

\subsection{Habitat Connectivity Zones}

Habitat connectivity zones (HCZ) are delineated and mapped survey sites where habitat information is collected from one to two vantage points along the edges or within the center of the zone. HCZ are a standard unit, 500 x 500 meter area, where repeat surveys are encouraged to score for habitat quality using the Metro Habitat assessment sheets and species specific scorecards (Appendix B: Forms). Habitat connectivity zones (HCZ) were digitized using ArcMap 10.6x, according to study site scale, management goal, and maximum line of sight for a surveyor. In Gresham East Buttes, forty HCZ were designated based on a combination of a-priori management goals including multi species and multi directional connectivity maps produced in Circuitscape to streamline surveying. I then scored Northern Red-legged Frog (Rana aurora) habitat quality and connectivity results across these forty units.

Prior to digitizing HCZ boundaries I used the Circuitscape 4.0 ArcMap 10.6x extension tool to create a species-specific impedance raster using reclassified habitat values from the specie's model: Habitat pixels have an impedance value of 1, permeable pixels have an impedance of 10 , and barriers have an impedance value of 1000 so as to weight the model toward avoiding barriers (Appendix C: Additional Data). The source and ground node inputs (i.e. starting and ending locations for connections) were four forested buttes within the East Buttes area, Gresham Butte, Gabbert Butte, Jenne Butte, and Hogan Butte. These buttes are north of Butler Avenue and the Multnomah County boundary line where species like $R$. aurora are closely monitored in the Johnson Creek 
Watershed. The Circuitscape all-to-all connectivity option resulted in a raw current map output (Figure 2). The connectivity 'current' value output maps were stretched on a logarithmic scale to increase the visibility of the highest connectivity values and evenly distribute connectivity values for species comparisons.

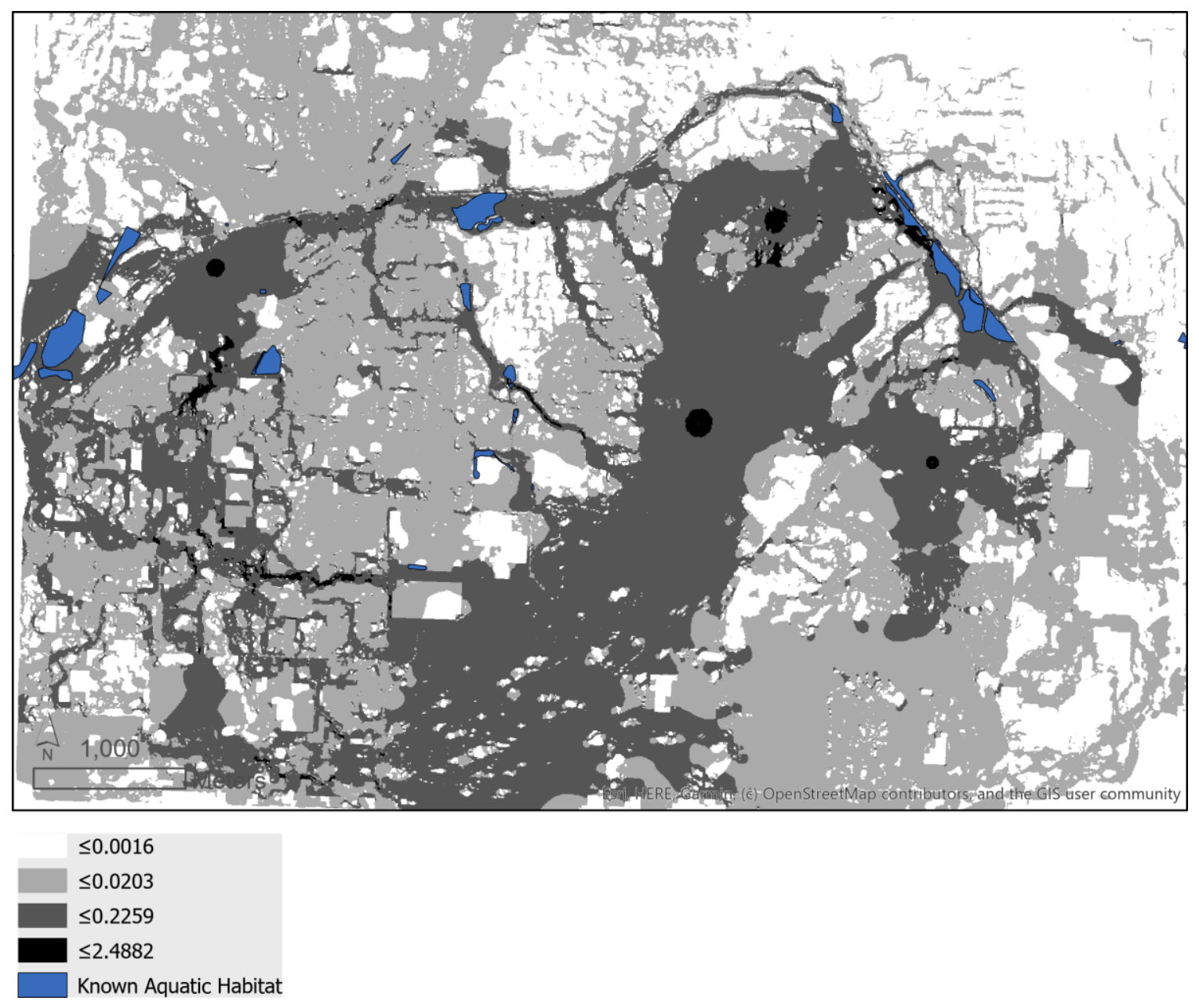

Figure 2. Circuitscape Raw Output

Preliminary Northern Red-legged frog (R. aurora) connectivity model of the East Buttes Region study area 44 square kilometers (Datum: GCS_North_American_1983, Projection: NAD83 UTM Zone 10N, Extent: *West longitude $-122.498315 *$ East longitude $-122.396333 *$ North latitude $45.502255 *$ South latitude 45.451742)). The inputs to Circuitscape were four buttes set as nodes Gresham, Gabbert, Jenne and Hogan Butte. 
The preliminary HCZ were digitized based on a 250 meter buffered centerline where the highest connectivity areas were located. Forty (40) habitat zones, approximately 500 x 500 meters each were adjusted by size and shape to best contour landscape features and property lines visible on aerial maps (Figure 3, 4). Each zone edge was placed on a road barrier, waterway, or other barrier feature such as fencing, if they completely bisected the zone. Connective overlap between adjacent $\mathrm{HCZ}$ was at minimum 50 meters and typically between $250-500$ meters wide. This method for delineating $\mathrm{HCZ}$ would ensure surveyor line of sight was possible to completely fill out assessment sheets consistently across the East Buttes area. Habitat assessment sheets consist of five main habitat characteristic groups: connectivity patch and matrix characteristics, water source, vegetation, other structural components, and human disturbance. Before assessing the field scores, GIS data is pre-populated into the assessment sheets for each HCZ. Thirty-four (34) GIS and field collected habitat characteristics are collected for each HCZ. The process takes approximately a half hour to an hour depending on $\mathrm{HCZ}$ complexity such as high vegetative density or diversity (Appendix B: Forms). 


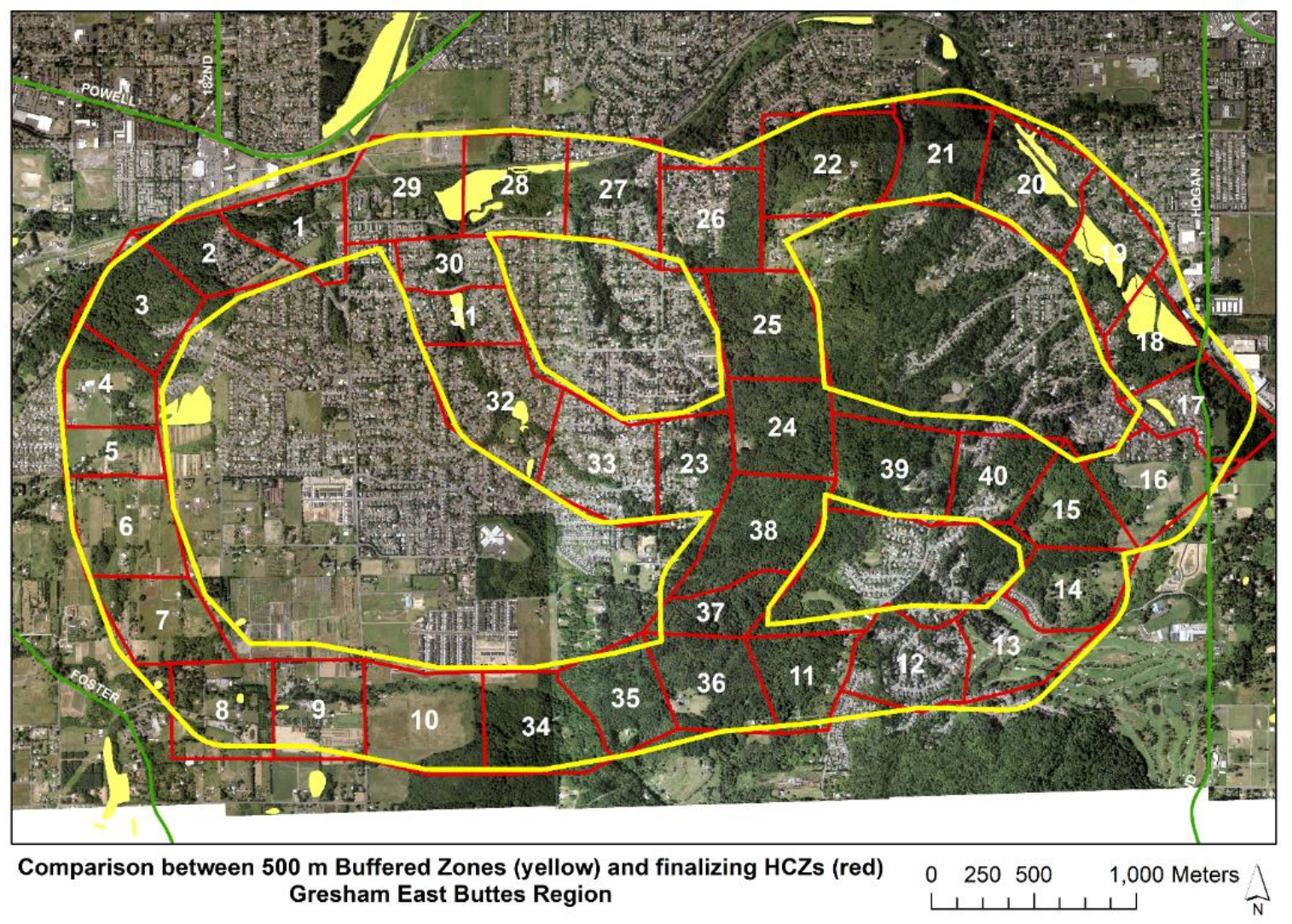

Figure 3. Habitat Connectivity Zones in Gresham East Buttes, Oregon

The original bounds of the habitat connectivity zone (HCZ) in yellow are delineated along a 250 meter buffered centerline on the highest connectivity values outputted from Circuitscape. The HCZ boundaries in red were custom adjusted to fit the study site features such as roads, topography, or site access points. 


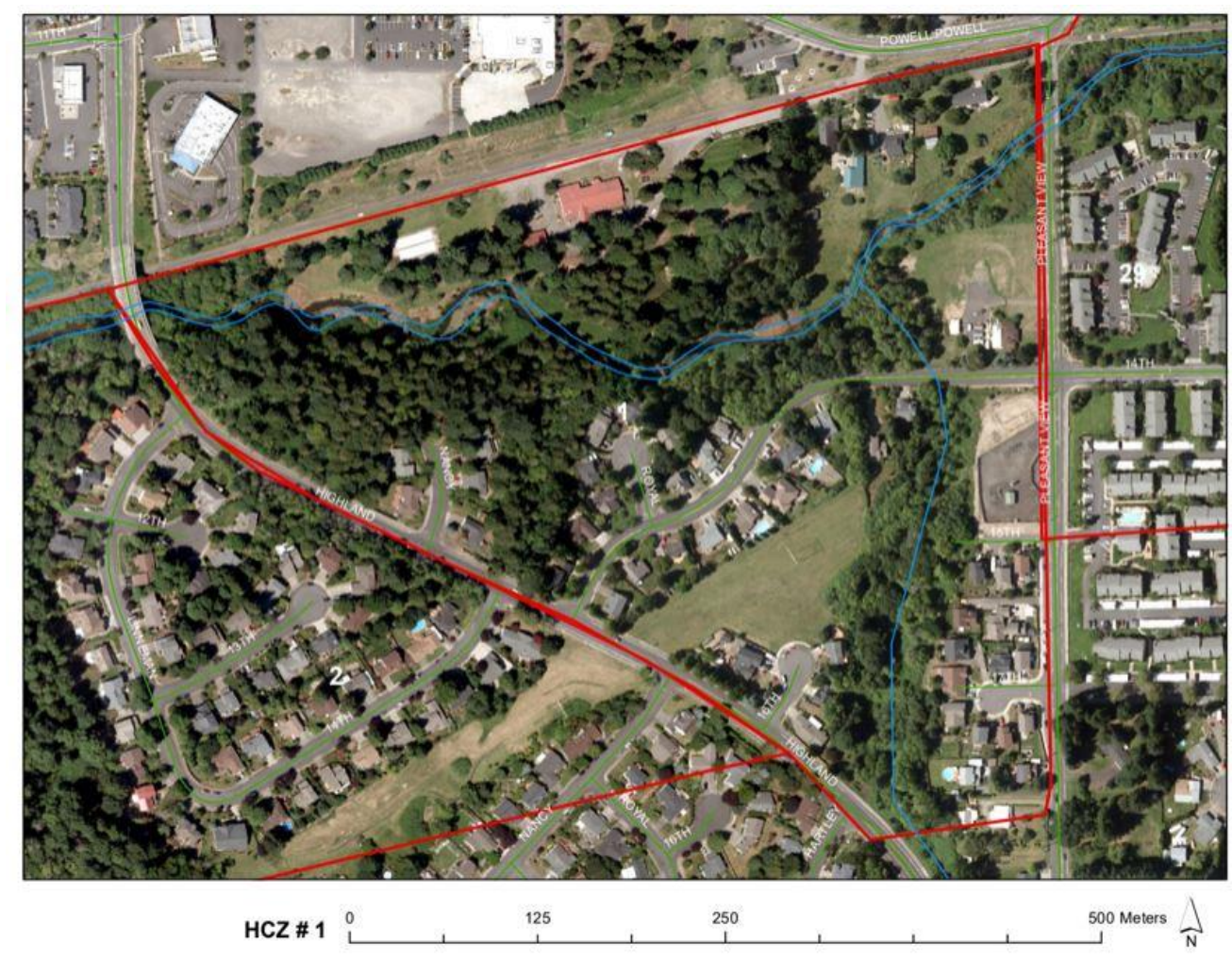

Figure 4. Habitat Connectivity Zone Close-up along Johnson Creek, Oregon

This site is an example of a finalized Habitat connectivity zone (HCZ, red lines). A habitat assessment is conducted from one to two vantage points along the edges or within the center of the zone if possible.

\subsection{GIS and Field Data Collection}

GIS data was populated into an excel spreadsheet adapted from the Metro

Regional Habitat Connectivity Toolkit's habitat assessment sheets (Appendix B: Forms).

Landcover data layers, five-meter Regional Conservation Strategy and Metro RLIS

Wetlands, were used to derive GIS data for fifteen (15) rows of habitat characteristics in

the Habitat Assessment sheets (PSU-INR, Metro RLIS Appendix B: Forms). Habitat data is derived using ArcMap 10.6x tool tabulate area, or measurement tools for each HCZ. 
The data sources and GIS processing steps for each habitat characteristic are outlined in detail in Appendix A: Glossary.

Field data was populated into an excel spreadsheet adapted from the Metro Regional Habitat Connectivity Toolkit's habitat assessment sheets (Appendix B: Forms). Nineteen (19) rows of habitat characteristics from the assessment sheets were collected. Depending on surveyor line of sight, sites were visually assessed from a central vantage point, or along at least two edges of the HCZ boundary, if applicable. An initial 5-15minute inventory was conducted to familiarize with the site prior to recording data. If access was not permitted at the site, a combination of visual assessment and aerial photos were used and marked on the assessment sheet. Additionally, field verification of GISderived habitat characteristics were marked and recorded if field verification was different from GIS results, GIS inaccuracies were recorded as well.

\subsection{Species Scorecard}

It is only at the scorecard stage of this process, when species-specific habitat quality scores are generated for each survey site or HCZ. Northern Red-legged Frog scorecards were developed from peer review and expert-feedback completed in 2018, with additional revisions currently in progress (PSU-Metro. In progress). Based on each habitat characteristic, peer-reviewers such as regional wildlife experts assigned scorecard values of 0-3 representing habitat (3), permeability (2), or barrier (1) effects features had on the species ability to move across the landscape. Scores with zero (0) indicate no contribution, and scores with n/s (not scored) were not included in the total possible 
score. Additional weighting schemes from 0-9 (in red type, multipliers) emphasize a habitat characteristic's importance for species movement. Weights represent importance to functional habitat or connectivity requirements of the species such as open water (score x7) and downed wood (score x6) (Appendix B: Forms). Scores and weights assigned to the Northern Red-legged Frog scorecard are regularly updated as more information on functional habitat requirements, and movement behaviors are reviewed.

In a spreadsheet, habitat characteristics are scored using the species-specific scorecard rubric and habitat quality scores are presented as a proportion of recorded sum out of the total possible sum score (Appendix B: Forms, i.e. recorded sum score/total possible sum score, $340 / 389$ is equal to $87 \%$ habitat score).

The species scorecard is regularly updated as new information about movement behaviors, functional traits, and influence of environmental factors are uncovered. The field surveyor would have an advantage of assessing potential connectivity areas and weight indirect influences on wildlife movement as needed.

\subsection{Comparison between GIS and Field scores}

To compare any possible differences between GIS and field collected habitat quality scores, the results for forty $\mathrm{HCZ}$ in Gresham East buttes were compared using Spearman's rank correlation coefficient for non-normally distributed data. This coefficient was calculated to determine if GIS and field scores were significantly correlated (95\% confidence interval, $\mathrm{p}>0.05$ ). If the two scoring techniques are highly correlated, then the time intensive field work would be redundant and unnecessary. However, if they are not 
correlated then each score would be contributing unique information and would argue the use of the Metro Toolkit to best assess habitat quality.

I hypothesized that if the two types of scores were different then the magnitude of difference might be related to development. Hence, I categorized agriculture and urban development intensity values obtained from recent 30 meter landcover data and reclassified these values into a single development class (PSU-INR 2018). Development was coded as value $=1$, and natural landcover was coded as value $=0$ (Appendix C: Additional Data). I used tabulate area to calculate the percentage development for each HCZ. I plotted results as a line graph along an axis of percent development to determine whether patterns, such as an increasing difference, between GIS and field collected habitat quality scores occurred.

4. Results

\subsection{GIS and Field Data Habitat Quality Score}

The Gresham East Buttes GIS derived habitat quality scores ranged from $27 \%$ to $74 \%$, with a mean of $54 \%$. Field collected habitat quality scores ranged from $37 \%$ to $79 \%$, with a mean of $60 \%$. There was low positive Spearman's ranked correlation coefficient between GIS and field scores, coefficient=0.19 (Figure 5). However, this correlation was not significant using a sample size of 40 habitat connectivity zones, pvalue $=0.08, p>0.05,95 \%$ confidence interval. Field scores were higher than GIS scores at $72 \%$ of the habitat connectivity zones surveyed. This indicates that the two scores are assessing different types of data. 


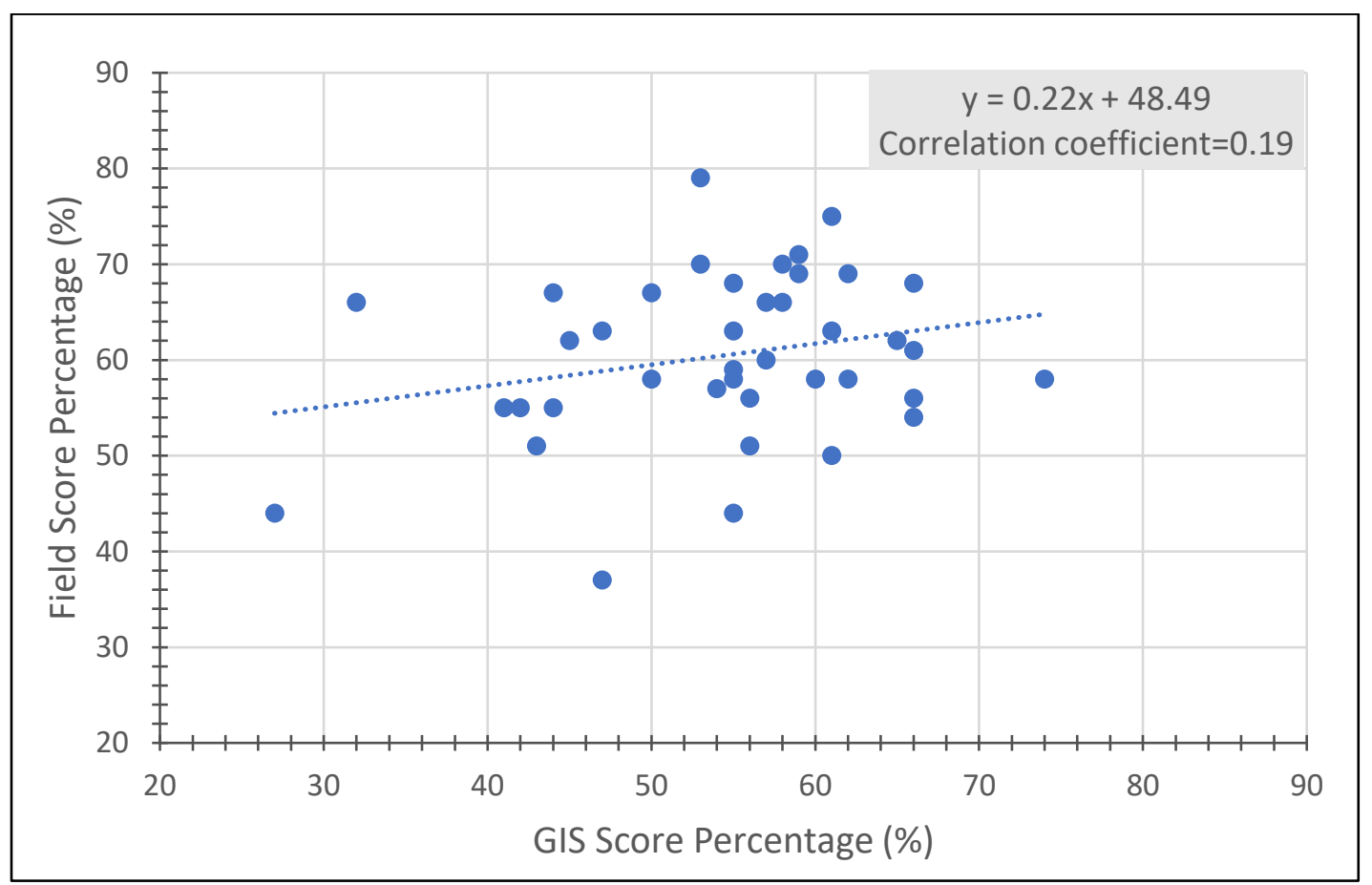

Figure 5. Spearman's Ranked Correlation Coefficient Results in Gresham East Buttes, Oregon

Across forty surveyed habitat connectivity zone survey sites in the Gresham East Buttes, assessed in early summer 2018, there was low positive correlation associated between GIS scores and field scores using Spearman's ranked correlation (correlation coefficient $=0.19, \mathrm{p}$-value $=0.08,95 \%$ confidence interval $\mathrm{p}>0.05)$.

\subsection{Differences between GIS and Field Scores along development gradient}

The habitat connectivity zones ranged from $8 \%$ - 98\% developed, including low, medium, high intensity urban and agriculture landcover categories (Figure 6). We expected the gap between GIS scores and field scores would increase as development increased however there was no interdependence or clear magnitude of difference between the GIS and field scores along a development gradient (Figure 7).

Using Spearman's ranked correlation, there was low positive but insignificant correlation between GIS and field scores. Overall, field scores were higher than GIS 
scores, however, the difference between GIS and Field scores did not directly increase as urbanization increased. The greatest difference in GIS and field scores was a difference of 34 percentage points at HCZ 33 (field score 66\%, GIS score was 32\%). This zone is located along a narrow vegetated strip, Butler Creek's riparian corridor, which is surrounded by suburban development and has known occurrence of Northern red-legged Frog. There was no difference between GIS and Field scores at one HCZ, HCZ 19 located along a mixed forested and suburban portion of the Spring-Water corridor trail parallel to Johnson Creek.

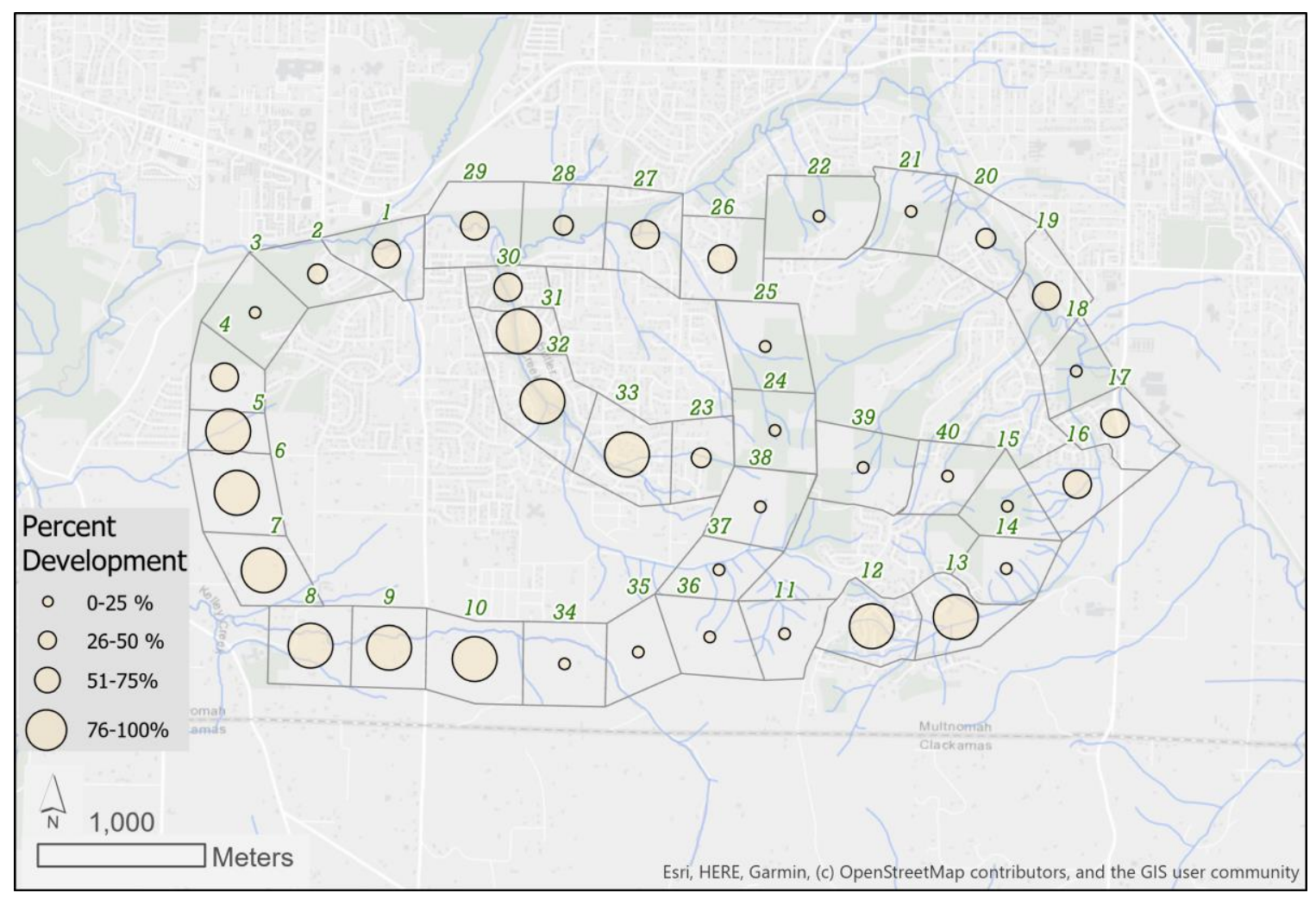

Figure 6. Percent Development in Gresham East Buttes, Oregon

GIS estimated percent development for forty habitat connectivity zones in the Gresham East Buttes. The developed category included any urban and agriculture land cover. 


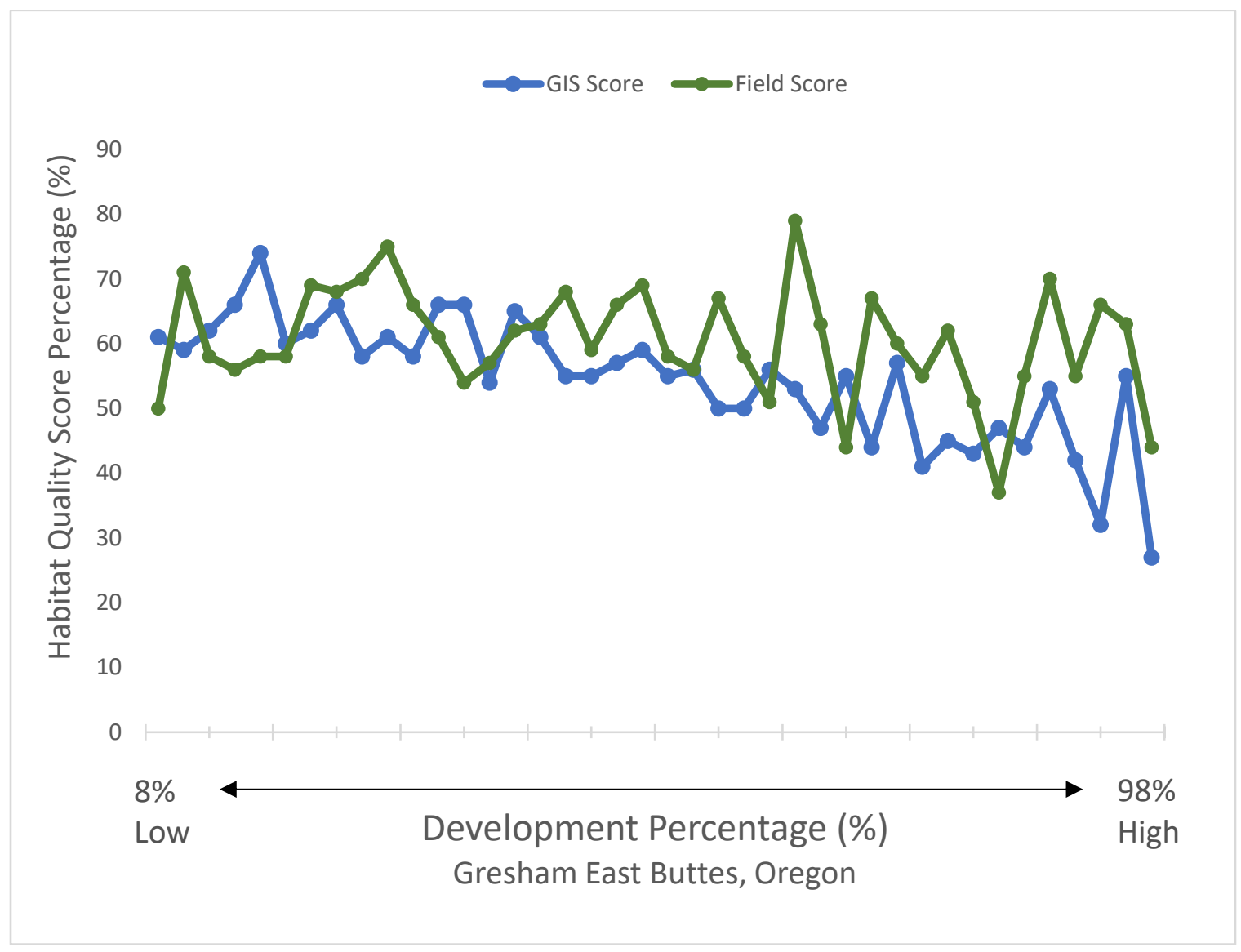

Figure 7. Comparison between GIS and Field collected Habitat Quality Scores in Gresham East Buttes, Oregon

Habitat connectivity zones were arranged along a gradient of low to high development percentage (percent area per survey zone), left to right on the horizontal axis which includes low, medium, high intensity urban and agricultural development land cover types. The magnitude of difference between GIS and field habitat scores did not have a clear pattern along a gradient of urbanization. 


\section{Discussion}

Conservation managers should use field assessed habitat data to characterize the state of habitat quality and management potential. Field collected data from the Metro Toolkit habitat assessments provides additional information on habitat function and anthropogenic influence that is not redundant, or highly correlated to GIS data in the Gresham East Buttes. The magnitude of difference between GIS and field scores at each survey site did not show a clear relationship to increased development area. Some equally developed zones had higher field scores and others had higher GIS score results. This reaffirms the need to combine GIS and field data to and relate structural habitat characteristics to functional habitat quality with increasing human influence. By testing habitat assessment tools like these, species-specific habitat quality thresholds and baseline information can be used to derive conservation potential at different configurations and scales of management across urbanizing areas (Chapter 4: Applications).

Contributions of field-collected habitat quality assessments:

The GIS and field methods employed in this thesis project contribute to a suite of tools measuring urban connectivity, quantifying wildlife movement and habitat quality in a standardized way (McRae et al. 2012; Lapoint et al. 2015; Nor et al. 2017). The use of the Metro Toolkit and field methods, although still in development, provides an additional context for urban wildlife movement that GIS alone cannot capture. Remotely sensed and GIS-derived environmental parameters are used primarily for preliminary 
assessment of survey sites (Gomez-Rodriguez et al. 2008; Spear et al. 2010; Schroeder et al. 2015). These data can be misclassified, and broadly categorized into structural variables such as forest cover, masking understory vegetation or human influence such as recreation activity. Wildlife require functional habitat to migrate, forage, and survive long term especially under anthropogenic disturbances. The Metro Toolkit uses biological research and field collected variables to inform initial GIS-based connectivity model assumptions. A caveat of using analytical tools in isolation is it's not a one-size fits all model. Typically, model parameters, scores, and weights are selected because it is interpretable for the user and their region. These models represent potential wildlife movement until cross-validated with competing models or tracking data. It is necessary to apply model sensitivity analysis to evaluate the intended usage and limitations of specific connectivity models before they are implemented in combination with the Metro Toolkit (Singleton and McRae 2013; Lacher and Wilkerson 2014).

The Metro Toolkit can generate permeability scores in addition to habitat scores for evaluating wildlife movement and connectivity potential. Although permeability assessments, demographics (i.e. occupancy), and metapopulations (i.e. genetic dispersal) were not evaluated in this scope of research, the Gresham East Buttes example lays the foundation for developing analytical tools in terrestrial urbanizing environments, places often underrepresented in the broader scope of connectivity research (Chapter 4). 
Limitation of field-collected data:

In addition to testing the field-assessment contributions of data types, another goal of this chapter was to discuss the potential limitations of analytical, expert-based tools used by conservation managers. It is unclear if field scores generated by the Metro Toolkit represent substantially more accurate habitat scores than what is generated using GIS-derived data alone. Low GIS scores may instead indicate missing information not verified by experts in the field, or misclassification from remotely sensed data, increasing the gap between GIS and field scores. However, a higher field score would indicate potentially better-quality habitat than what was initially generated from the GIS scores alone which still provides conservation managers with new information they would not have obtained through GIS methods. 


\author{
Chapter 3 \\ Sensitivity Analysis in the Field: \\ Case Study Northern Red-legged Frog (Rana aurora)
}

\title{
1. Background
}

Field-collected habitat characteristics and expert-scoring requires a sensitivity analysis to discuss method limitations and uncertainties. Field collection and habitat scoring, although standardized, is still subject to variations in expert opinion and decision-making goals (Johnson and Gillingham 2004). Unlike field collected data, GIS data sensitivity analysis is a relatively cut and dry approach utilizing subsets of data to "train" model predictions, as well as to make informed, weighted inferences of habitat features utilized by wildlife (Romero-Calcerrada and Luque 2006). GIS data is primarily limited by accuracy and temporal aspects rather than human subjectivity, but the data is often mapped and categorized as a ranking of important environmental parameters and thresholds through expert opinion, which will inevitably be subjective.

For connectivity maps to be applied to a variety of regional goals (i.e. transportation, natural resource, and conservation goals), the underlying data used to build these maps should be as transparent as possible, which includes potential uncertainties. By conducting a sensitivity analysis for habitat quality scores generated from field-collected data, conservation managers can interpret scores in order to determine whether changes to these scores over time are a product of user error or visibility and seasonality of habitat features at the survey site. This will inform managers whether repeat surveys are needed and whether different field-collection methods should be employed to increase field-collection reliability. 
Q2: Which habitat characteristics are sensitive to field survey methods and can potentially influence habitat quality scores generated from managed, intact forest habitats?

I evaluated the Metro Toolkit scorecard's sensitivity to field data collection methods. During winter migrations of the Northern Red-legged Frog in 2019, surveyors recorded habitat characteristics at a relatively natural forested site, Forest Park (Appendix D: Forest Park Radio-telemetry Data). I evaluated the influence of the Metro Toolkit scorecard's scoring and weighting scheme in order to identify whether certain habitat characteristics were not collected or visible to field surveyors. Missed or misclassified data could drastically change the generated habitat quality score results, especially for habitat characteristics that are assigned weighted importance multipliers by species experts and land managers in the region. These multipliers highlight wildlife movement, functional habitat, or other needs such as migration or breeding dependencies on habitat characteristics. Misrepresented or missing field collected data could be a potential limitation to the Metro Toolkit as well as other habitat scoring tools applied to connectivity.

I evaluated the Metro Toolkit's limitations at field sites in Forest Park. The habitat quality scores were generated completely from field-collected data and assess seven distinct, occupied sites, where frogs were recaptured using radio-telemetry in 2019. These recapture locations were also where the radio-telemetry teams conducted health checks on frogs (Appendix D: Forest Park Radio-telemetry Data). 
The Northern Red-legged Frog scorecard includes expert-evaluated functional habitat characteristics which are weighted using importance multipliers from $\mathrm{x} 5$ to $\mathrm{x} 9$ (Appendix B: Forms, red type). The species experts were knowledgeable on the regional behaviors, breeding, and movement capabilities of frogs in the Portland Metropolitan Region. I expect the sensitivity of the scorecard to specific habitat characteristics, such as seasonal water sources or visibility of ground cover, may inaccurately generate higher or lower habitat quality scores than intended for terrestrially migrating adult frogs especially for a weighted habitat feature. A potential limitation of the scorecard is its ability to capture variation of fine-scale habitat that are permeable for frog movement, such as pathways between functional habitat, aquatic breeding sites and forested uplands, in both natural, and especially urbanizing areas with complex spatial configurations. If scoring differences arise in the relatively homogenous forested natural site, Forest Park, then I would recommend adjustments to the scorecard prior to assessing urban environments.

\section{Sites}

Forest Park is $\sim 21$ square kilometers of relatively intact, natural forest North of downtown Portland. The study area is located in the Northernmost portion of the park, northwest of the town Linnton (Figure 8). This part of Forest Park contains dense, mature Douglas fir-Hemlock forest with shrub and herbaceous understory, headwater streams and steep slopes up to 340 meters in elevation. The park features some pedestrian trails, powerlines, clear-cuts within the forest, and housing development along the edges of the forest which may pose potential anthropogenic influences to frog movement. Forest Park 
is considered a biodiverse anchor habitat for wildlife and native vegetation and is protected under conservation initiatives (Forest Park Conservancy and Forest Park Alliance 2013). The Forest Park Desired Future Conditions plan (DFC) and Portland 2035 comprehensive plan also incorporate habitat corridors into long-term park and urban management goals through vegetation planting and design (City of Portland- Forest Park Desired Future Condition 2011; City of Portland- 2035 Comprehensive Plan 2018). These plans focus on avian and plant species conservation and contain minimal terrestrial management recommendations for amphibian species due to limited knowledge of their home ranges. From radio-telemetry surveys in 2018 and 2019, R. aurora was observed travelling through Forest Park in close association with mature Douglas Fir Forest and mixed conifer forests, habitats identified in the DFC (Appendix D: Forest Park Radiotelemetry Data). 


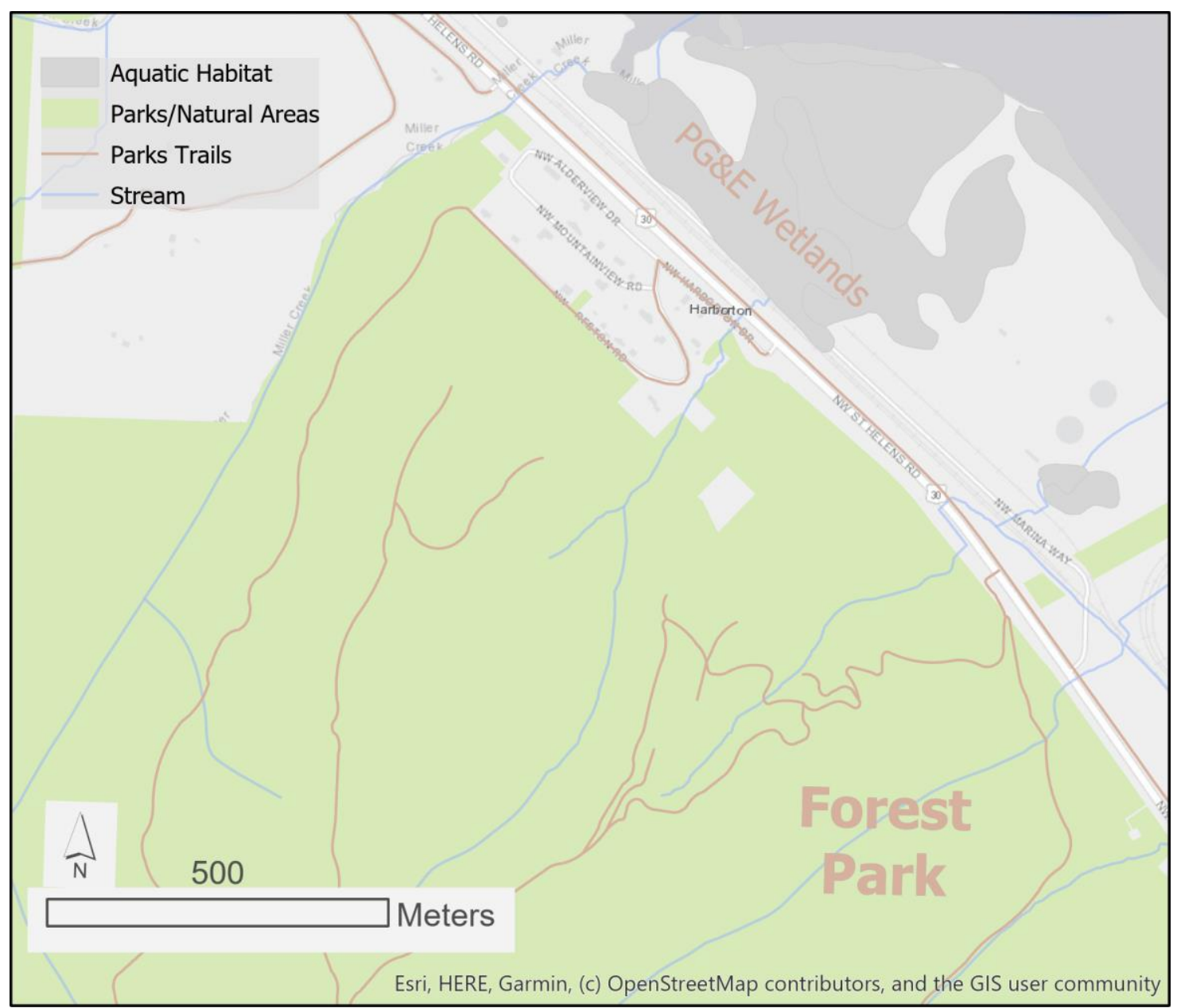

Figure 8. Forest Park Study Site, Linnton, Oregon

Forest Park is the largest publicly owned natural area in the Portland Metropolitan region. Extent of study site contains forested and developed areas North of Linnton, Oregon (Datum: GCS_North_American_1983, Projection: NAD83 UTM Zone 10N, Extent: *West longitude -122.804854 *East longitude $122.802290 *$ North latitude $45.613990 *$ South latitude 45.611222$)$.

Movement data and habitat characteristics were collected in Northeast Forest Park, adjacent to Harborton Drive and Highway 30-St. Helens Road. This Northern point of the Metro boundary line and the Multnomah County line contains important aquatic habitat at the confluence of the Willamette and Columbia Rivers. Off-channel wetlands, Harborton wetlands and Burlington Bottom wetlands (less than four kilometers apart) are 
approximately 300+ meters East of Forest Park. The frogs tracked in Forest Park primarily breed at the 339 acre Harborton-PG\& E wetlands, although other pond sites may support frogs from the same metapopulation (personal correspondence Harborton Shuttle). These restored wetlands are known to contain industrial contaminants, but they nevertheless are considered special habitat areas. These Willamette River floodplains/bottomlands provide microclimates, nutrient cycling, and water storage functions for the local ecosystem (City of Portland- Willamette River Natural Resource Inventory Report: Riparian Corridors and Wildlife Habitat 2009). After breeding, migrating frogs move upslope along a partially piped stream and into the forest interior. Their movements are staggered, and groups of frogs typically migrate at night when temperatures are above six degrees Celsius and there is enough moisture on the ground to cross paved roads.

Local access road Harborton Drive, Highway 30-St. Helens Road, and the adjacent rail lines separate the wetlands from forested uplands. Since 2014, Harborton Shuttle volunteers have relocated frogs and other amphibians during their breeding migrations. This form of voluntary barrier mitigation management occurs annually between the months of November and April. These efforts have reduced mortality along the highway, successfully transporting from 500 to over 1000 frogs a year (http://www.linntonfrogs.org/). 


\section{Methods}

\subsection{Forest Park Survey Sites}

Survey site delineation for Forest Park differed from Gresham East Butte methods (Chapter 2). Rather than digitize habitat connectivity zones (HCZ), I selected seven (7) field sites in Forest Park where we captured and conducted health checks on frogs between March and May 2019. Each site was greater than 50- 100 meters apart and is considered a distinct site. Locations were surveyed by two to four team members who walked a $250 \times 250$ meter area surrounding the center point, recapture location. GIS data of the ground surface is limited for this site due to the dense overstory, which is why the Metro Toolkit was used to assess habitat characteristics.

\subsection{Scorecard Sensitivity of Field Collected Habitat Characteristics}

A scorecard sensitivity analysis was used to identify the influence of field-verified habitat characteristics in a natural environment. The highest and lowest scoring sites in Forest Park were compared to determine whether certain habitat characteristics had over weighted influence on combined scores. I created a table containing 32 habitat characteristics, recorded data, and generated scores from the Northern Red-legged Frog scorecard Appendix B: Forms). The difference between each habitat characteristic's contribution to the combined habitat score was calculated to determine whether scorecard generated results were sensitive to the inclusion or omission of habitat characteristics recorded by field surveyors (Appendix C: Additional Data). 
4. Results

In Forest Park all collected data was field verified using the Metro Toolkit habitat assessments. Overall habitat quality scores across seven sites with known frog presence in Forest Park ranged from 56\% - 75\%. Habitat scores differed $+/-19 \%$ between the highest (Frog\#11/45.612333, -122.80485) and lowest (Frog \#7/ 45.613449, -122.804557) scoring survey sites (Appendix C: Additional Data). Habitat characteristics, particularly water source and other structural components were the top contributors to the combined habitat score and contained weighted multipliers. Overall, water source scores contributed to $33 \%$ of the combined habitat score, and other structural components contributed to $24 \%$ of the combined habitat score (Figure 9). When comparing the lowest and highest habitat scoring sites in Forest Park the recorded data for water source characteristics were $53 \%$ different, and for other structural components they were $66 \%$ different. The highest scoring zone had presence of a stream within the survey area, and presence of duff/thatch layer as ground cover. The lowest scoring zone did not have presence of water source, had lower levels of downed wood, and had no visibility of duff/thatch layer ground cover. Having no water source at this low scoring site, the associated stream characteristics (i.e. distance from water, seasonality, bank condition, and substrate) at the site received ' 0 ' scores, thus lowering overall habitat scores. Vegetation characteristic, riparian area percentage, also scored lower at this site due to the lack of a water source. The lowest scoring site also had greater conifer cover percent and greater evidence of human presence reflected in its combined score. 


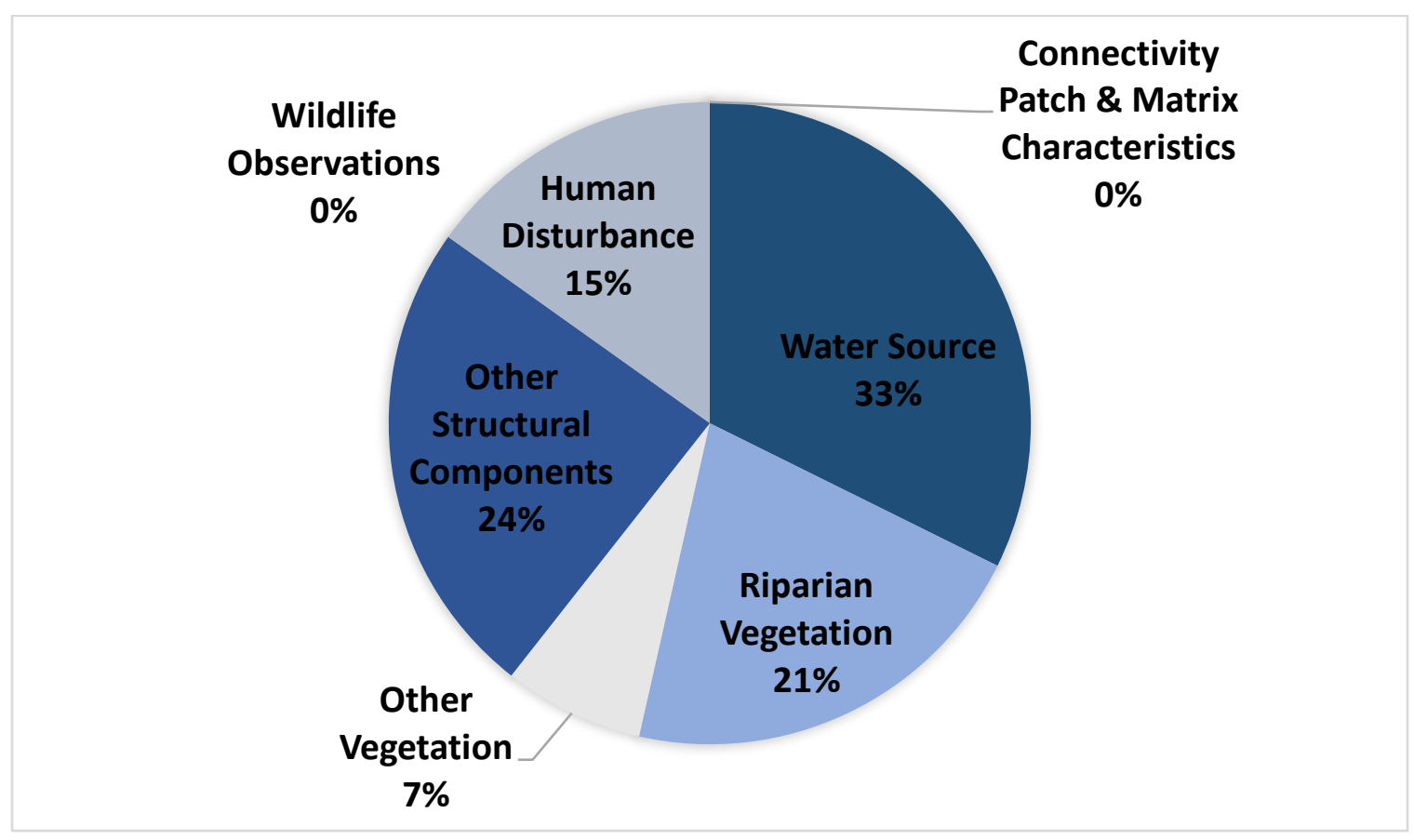

Figure 9. Scorecard Sensitivity of Field-verified Habitat Characteristics Collected in 2019, Forest Park, Oregon

The habitat quality scores were generated using the Metro Regional Habitat Connectivity Toolkit at seven sites in Forest Park where adult migrating Northern Red-legged Frogs were tracked using radio-telemetry between March and May 2019.

\section{Discussion}

Even when comparing the difference between the highest and lowest scoring sites at a relatively homogenous natural site, Forest Park, habitat quality scores ranged from $56 \%$ to $75 \%$. From the sensitivity analysis at known Northern Red-legged Frog (Rana aurora) locations the habitat quality scores were largely influenced by the presence or visibility of water and other structural components such as downed wood and duff/thatch ground cover depth during field collection. As water hydroperiod fluctuates, and as 
vegetative ground cover starts to grow seasonally, habitat assessments should likely be recorded during the main terrestrial movement times for adult stages of $R$. aurora.

Both urbanizing and natural sites have seasonal presence and visibility of moisture-retaining forests, ground cover patches, and hiding spaces for frogs during their migrations (Chan-McLeod and Moy 2007). Presence of frogs occurred at locations with sword ferns, low-lying herbaceous vegetation and hiding spaces such as root hollows and duff layer in Forest Park (Appendix D: Forest Park Radio-telemetry Data). Dense ground cover conditions may have obscured subterranean streams or cover objects utilized by frogs, lowering the field-verified habitat quality score at some surveyed sites which were primarily above-ground and under dense canopy with confirmed presence of frog activity (i.e. burrowing, migration, feeding) at these locations. Additionally, threshold values for forest and ground cover fragmentation, as well as distance between habitat patches, and minimum ground cover gaps must be identified for Northern Red-legged Frog movement in both natural and urbanizing sites in the Portland Metropolitan region to interpret scorecard results (Guderyahn, Smithers, and Mims 2016; Grand et al. 2017). 


\author{
Chapter 4 \\ Applications of Metro Regional Habitat Connectivity Toolkit \\ for Conservation Managers: \\ Case Study Northern Red-legged Frog (Rana aurora)
}

\title{
1.Background
}

\subsection{Need for Northern Red-legged Frog Connectivity Tools}

Currently, there is limited terrestrial habitat data collected for Northern Red-legged Frog (Rana aurora) in the Portland Metropolitan region. This precludes building aquaticterrestrial connectivity models at this stage (i.e. Circuitscape models) or defining thresholds for patch and distance requirements between habitat types. In order to overcome these data limitations, connectivity conservation managers require tools and methods to collect habitat data, and assess their region for connectivity status, restoration, barrier mitigation, or preservation of functional habitat required by wildlife to survive. This can be accomplished using preliminary habitat connectivity models in combination with the Metro Regional Habitat Connectivity Toolkit to visualize the current state of or potential for connectivity on the regional landscape. In this Chapter, I applied Circuitscape connectivity model methods, Metro Regional Habitat Connectivity Toolkit's habitat assessment methods (Chapter 2), and egg mass survey data collected in the Gresham East Buttes between 2006-2013 to explore the uses and limitations of habitat connectivity tools for conservation managers.

In the Portland Metropolitan region Rana aurora do not have a particular preference for old or new, natural or artificial water sources (Holzer 2014). Their aquatic habitat 
choices are structurally varied, ranging from small ephemeral pools, stormwater ponds, and restored wetlands. Populations are known to thrive in high density stormwater ponds especially in the urbanizing Johnson Creek Watershed, Gresham. It is not yet known whether movement behaviors differ between natural and urban areas but there is a larval stress carry over effect on the metamorphosed frog's ability to move across terrain, which is linked to body size and hydroperiod fluctuations (Bredeweg et al. 2019). There is uncertainty in how distance to terrestrial habitats and use of urban cover affects their survival. Frogs may be selecting moist remnant forest patches as stepping stones to reach better habitat where they may remain for longer periods of time across crucial dispersal periods (Chan-McLeod and Moy 2007; Saura, Bodin, and Fortin 2014). If they are unable to reach these better habitats in time they are at risk of desiccation. Connectivity tools developed to quantify urban influences on wildlife movement and survival thus provide valuable information to wildlife conservation managers.

Expanding development and agricultural land uses within the Willamette Valley have been noted as a cause of amphibian decline (Willamette Valley Conservation Study Strategic. Pacific Region, Portland, Oregon 2017). Recently Portland egg-mass data occupancy models were assessed at urban wetlands and stormwater ponds to determine if pond depth, hydroperiod, and distance to forest cover played an important role for $R$. aurora occupancy (Guderyahn, Smithers, and Mims 2016). Although the R. aurora's egg mass counts continue to range up to the 1000 s annually at some sites in the Portland metropolitan region, the frog's seasonally dependent habitat connections are increasingly at risk. Their habitat spans across natural and human modified perennial and ephemeral 
water sources including wetlands, streams, underground seeps, and reservoirs (Bulger, Scott, and Seymour 2003; Holzer 2014). Their use of stormwater ponds and parks in the region means connectivity is best suited for local-scale restoration and barrier mitigation strategies that can be readily implemented.

Predictive environmental variables associated with other pond-breeding amphibians' abundance and species richness in natural areas have been used to recommend $R$. aurora habitat management at other geographical locations and scales. The issue with this approach is that natural site characteristics may not translate to functional habitat use and availability in urbanizing environments. However, studies in New Hampshire linked 40\% to $60 \%$ forest cover within a 1000 meter radius from breeding wetlands were adequate to ensure species richness and abundance of larval stage frogs (Hermann et al. 2005). In British Columbia, Canada, R. aurora egg mass abundance increased with up to $96 \%$ forest cover within 50 meters from an aquatic breeding site (Bunnell et al. 2016). Few $R$. aurora connectivity studies have taken place in urban and surrounding terrestrial environments. The Puget Sound, Washington and Willamette Valley are the few examples of where these kinds of peri-urban research efforts have taken place. In the Willamette Valley habitat suitability and occupancy has focused on pond-breeding activities of both native and non-native amphibians, however the sites surveyed were selected as relatively unaltered or managed refuges to best study environmental associations in isolation, and away from intensive development (Rowe et al. 2019). Studies of R. aurora in peri-urban to urban sites in the Pacific Northwest were linked to closed canopies with a range of 50-60\% percent forest cover, dense understory vegetation 
of sword ferns, and habitat patch distances up to five kilometers from breeding sites (Hamer and Mcdonnell 2008; Hayes et al. 2008; Ostergaard, Richter, and West 2008; Holzer 2014; Guderyahn, Smithers, and Mims 2016; Grand et al. 2017). The influence of anthropogenic activity on $R$. aurora movement and habitat connectivity has not been studied extensively although it has been cited as a major gap in the collective understanding of the species' movement behaviors and survival in rapidly developing environments (Schuett-Hames 2004; Guderyahn, Smithers, and Mims 2016; Grand et al. 2017).

\subsection{Circuitscape Uses and Limitations}

Circuitscape connectivity models were paired with Metro Toolkit because of its analytical methods (using both quantitative and qualitative data) as well as its compatibility with demographic and genetic models. This tool uses circuit-theory, which creates arcs between nodes along the path of least resistance, such as pathways permeable for wildlife movement. This tool is particularly applicable for conservation managers planning for connectivity in heterogenous, and data limited landscapes (McRae et al. 2008). Circuitscape movement paths are hypothetical models used to aid management and planning goals that seek to construct or alter the function of the landscape (Gustafson 1998). This applied management approach uses heuristic evaluation and model parameterization to make decisions for habitat restoration or barrier mitigation. With this tool the user designates priority pathways or tests loss of connectivity and the impact it will have on wildlife movement. In this example, a loss of a primary connectivity 
pathway may reroute higher connectivity potential to other pathways with lower quality habitat. The user can consider these alternate pathways' restoration options that best suit wildlife needs.

For both GIS and field collected data, environmental variables' influence on wildlife habitat, and permeability are used to develop resistance rasters (impedance, cost used in Circuitscape) to produce hypothetical connectivity models and target management areas. Circuitscape incorporates field-collected data and weights both natural and anthropogenic influences on movement behaviors. For example, GIS-based data may not have information on construction light or noise levels in suburban areas when animals like Columbia black tailed deer are likely to crossroads. However, the indirect influence of light deter deer from crossing to quality habitat even though GIS data may categorize a smaller arterial road with low traffic as permeable for movement (Bliss-Ketchum et al. 2016). The influence of construction may last for months, altering migration routes for wildlife. If connectivity managers were to utilize remote sensing data to derive suitability based on GIS data alone rather than incorporate field-verified data, the age and resolution of the data could be missing daily and seasonal disturbances in urban environments (Poor et al. 2012; Sha et al. 2018).

\section{Applications}

I modeled predictive connectivity for the Northern Red legged Frog using the PSU-Metro species model impedance raster and Circuitscape (Chapter 3, 1.2 and 1.3. Appendix C: Additional Data). Circuitscape current maps were made using reclassified 
impedance values from the Northern Red-Legged Frog (Rana aurora) species-model resistance raster (Habitat/impedance value 1, permeability/impedance value 10, barriers/impedance value 1000). Two source and two ground nodes placed on buttes within the East Buttes extent and the Circuitscape all-to-all option was selected. The connectivity results were overlaid on to the seven pathways (from forty delineated habitat connectivity zones, HCZ, 500 x 500 meter survey sites, Chapter 2). Connectivity was visualized using a 4-class geometric interval of raw Circuitscape current values and classed using upper class intervals of $0.0016,0.02037,0.225,2.488$. These intervals represent low to high connectivity strength that can be compared across species ('current' values). I identified connectivity type visually as pinch points, sheet-flows, or braided linkages. Braided connectivity with low values and pinch points with high values were identified as targets for connectivity management due to the narrowness of connective areas potentially constricting wildlife movement or indicating potential barrier in the connective pathway.

The following criteria were used to identify $R$. aurora priority connectivity pathway management in Gresham East Buttes: (1) connectivity type, (2) habitat quality score, and (3) distance between known aquatic habitat and surrounding terrestrial habitat. Each criterion contributes information on the current state of $R$. aurora habitat connectivity in the East Buttes area and available data sources (Appendix A: Glossary). Pathways are aggregates of habitat connectivity zones (HCZ) delineated for surveying habitat (Chapter 2). These pathways were given the locational names North, East, South, West, Central 1, Central 2, and Central 3 based on their location in the Gresham East 
Buttes (Figure 10). Priority pathways were identified for potential connectivity, habitat restoration, or barrier mitigation management actions (Table 2).

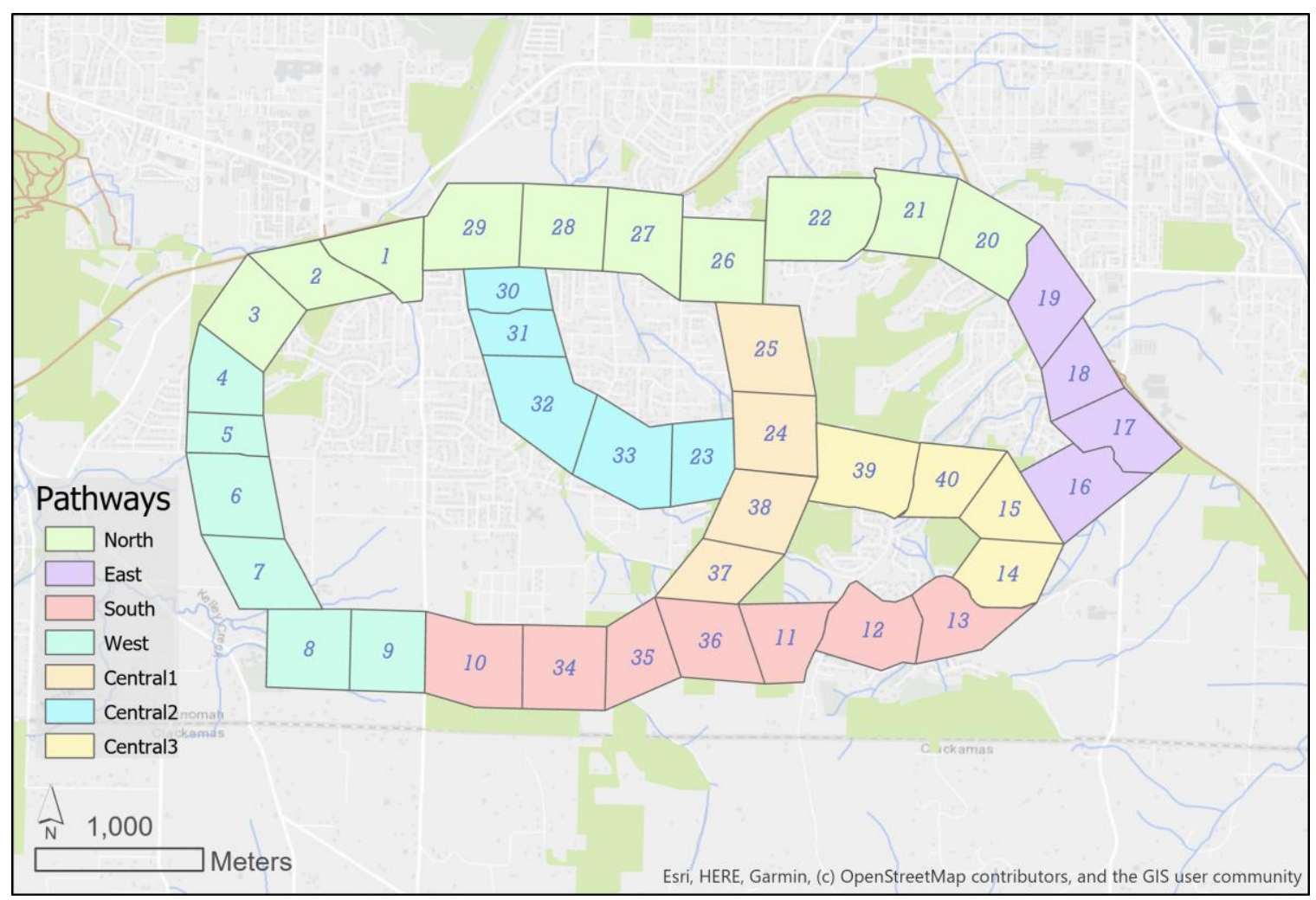

Figure 10. Connectivity Pathway Delineation in Gresham East Buttes, Oregon

Forty Habitat connectivity zones (HCZ) were combined and designated as pathways. Regional names were given to each predictive pathway representing its general location in the Gresham East Buttes area. When possible, the connective zones contained similar dominant matrix types, either urban or agricultural. Only one pathway (West) has an agriculture dominant matrix type. 
Table 2. Urban Habitat Connectivity Management

By applying connectivity tools conservation managers can identify urban-specific connectivity management actions, and target habitat restoration, or barrier mitigation using information about the habitat quality (i.e. habitat score) or availability/distances between aquatic and terrestrial habitats using the following criteria (1) Connectivity Type (2) Habitat Quality score and (3) Aquatic and terrestrial habitat distance and type.

\begin{tabular}{|c|c|c|}
\hline Criteria Type & Regional Data Tools & Potential Management Action \\
\hline $\begin{array}{l}\text { (1) Connectivity Type } \\
\text { (i.e. Low connectivity } \\
\text { values or connectivity } \\
\text { type is braided/pinch- } \\
\text { point indicating a } \\
\text { potential barrier to } \\
\text { movement. Models can } \\
\text { come from Least Cost } \\
\text { Path, Circuitscape and } \\
\text { other types) }\end{array}$ & $\begin{array}{l}\text { species-model } \\
\text { resistance raster } \\
\text { (PSU-Metro 2018) } \\
\text { Reclassified/ } \\
\text { weighted impedance } \\
\text { values for } \\
\text { Circuitscape }\end{array}$ & $\begin{array}{l}\text { 1.Track movement and validate connectivity } \\
\text { model pathways to determine if frogs cross } \\
\text { certain connectivity thresholds such as high } \\
\text { current value pinch-points. } \\
\text { 2. Confirm restricted movement permeability at } \\
\text { predicted pinch points or low current value areas } \\
\text { where barrier mitigation or habitat restoration is } \\
\text { feasible. } \\
\text { 3.Initiate Backyard habitat or volunteer } \\
\text { programs to add sword ferns, low ground cover } \\
\text { vegetation and structural diversity to woody } \\
\text { debris and moisture retaining vegetation patches }\end{array}$ \\
\hline $\begin{array}{l}\text { (2) Habitat Quality } \\
\text { Score } \\
\text { (i.e. proportion of } \\
\text { habitat, relative isolation } \\
\text { of zone) }\end{array}$ & $\begin{array}{l}\text { Metro Toolkit } \\
\text { Habitat assessment } \\
\text { survey } \\
\text { and species } \\
\text { scorecard, } \\
\text { (PSU-Metro 2018) } \\
\\
\text { Digitized } \\
\text { HCZs/pathways }\end{array}$ & $\begin{array}{l}\text { 1. Repeat habitat assessment surveys to complete } \\
\text { baseline habitat scores for the site across } \\
\text { seasonal changes and years. Set goals to increase } \\
\text { habitat score to a specific threshold. } \\
\text { 2. Model environmental variables to occupancy } \\
\text { of aquatic and terrestrial habitats or other } \\
\text { functional habitat requirements }\end{array}$ \\
\hline $\begin{array}{l}\text { (3) Aquatic and } \\
\text { Terrestrial Habitat } \\
\text { (distance and type) } \\
\text { (i.e. occupancy data, } \\
\text { abundance, radio- } \\
\text { telemetry locations) } \\
\text { (i.e. public lands, } \\
\text { sensitive habitat, } \\
\text { minimum core patch } \\
\text { sizes) }\end{array}$ & $\begin{array}{l}\text { City of Gresham and } \\
\text { Johnson Creek } \\
\text { Watershed } \\
\text { Amphibian Survey } \\
\text { shapefiles } \\
(2007-2015) \\
\\
\text { Oregon Statewide } \\
\text { Habitat Map } \\
\text { (PSU-INR 2018) }\end{array}$ & $\begin{array}{l}\text { 1. Validate minimum core area or patch } \\
\text { requirements. } \\
\text { 2.If there is no core area adjacent to the aquatic } \\
\text { habitat, measure distance to next terrestrial patch } \\
\text { or validate with radio-telemetry to determine } \\
\text { occupancy in nearby patches at varying distances } \\
\text { 3. Integrate connectivity management into } \\
\text { stormwater and park restoration plans }\end{array}$ \\
\hline
\end{tabular}


Criteria 1: Connectivity Type

Circuitscape's current map values (connectivity values, not logarithmically transformed) ranged between $0-2.48$. The maximum values at connectivity pathways ranged from 0.29 to 2.48 . South pathway had the lowest maximum connectivity values and Central 1 pathway had the highest maximum connectivity values. However, connectivity values alone cannot be used to determine connectivity type. Using a visual assessment of connectivity type, the dominant type in the Gresham East Buttes were braided linkages (Figure 11). The North, East, Central 2, and West pathways had braided or pinch-point connectivity types. The North pathway-Springwater corridor trail had braided linkages between Jenne Butte and Gresham Butte. There are two localized pinch points along SW Highland Drive and Pleasant View Drive, indicating potential road barriers. The East pathway-Hogan Butte had braided low current values on the eastern end of the pathway nearby to the open spaces at the Persimmon country club. A sheet flow linkage, the ideal connectivity type allowing relative ease of movement, was present between the Central and south pathway, along the Towle butte natural area. The Central 2 pathway follows Butler Creek and has narrow braided linkages along the stream with localized pinch points from SE Butler Creek Park to SW Willow parkway, indicating potential road barriers The West pathway had braided linkages flowing in different directions outside of the connective pathway. There are localized pinch points toward the center of the pathway between Jenne Butte Park to SE Mckinley Road and along the south end at Kelley Creek. 


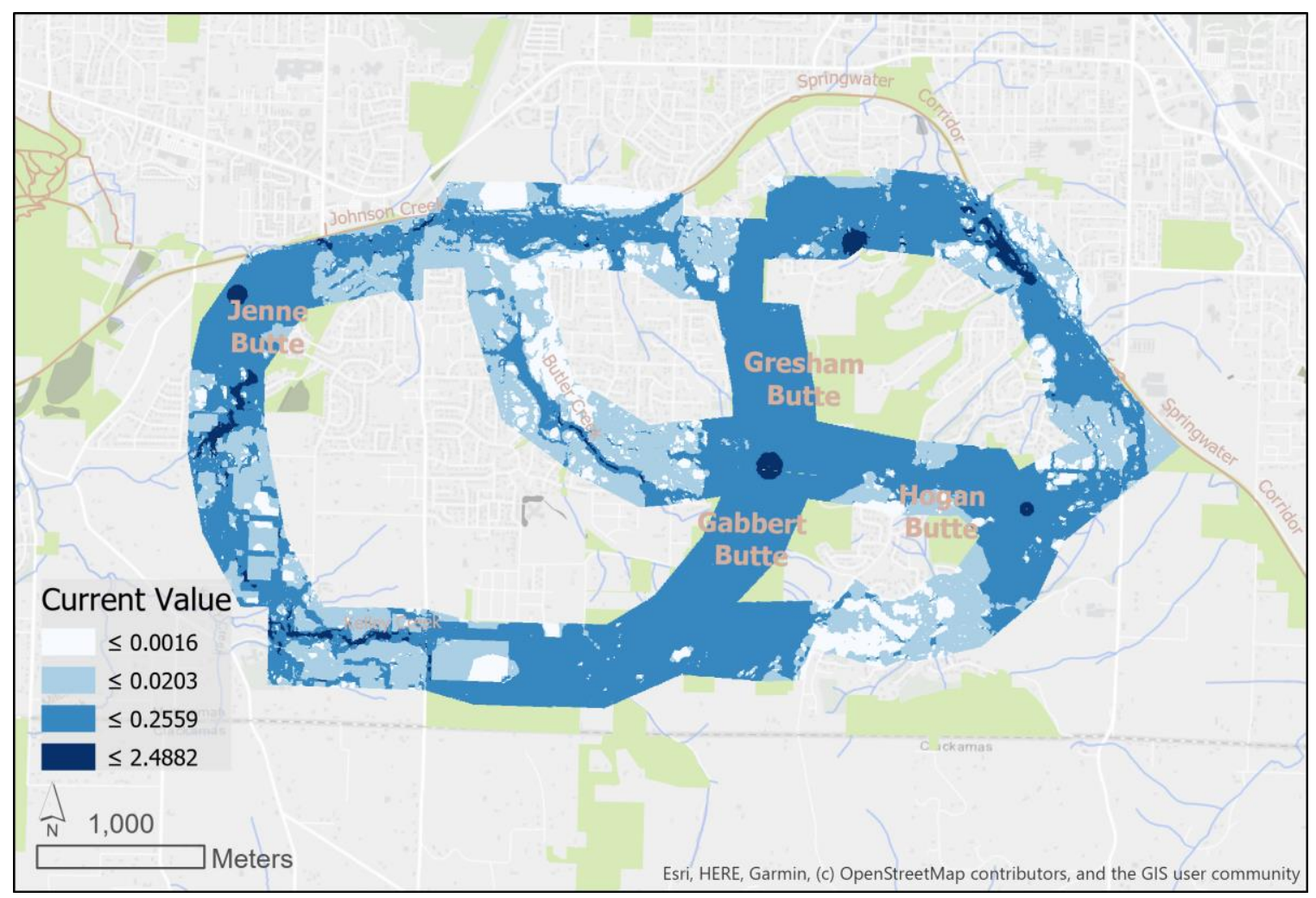

Figure 11. Criteria 1: Circuitscape Connectivity Model in Gresham East Buttes, Oregon

The dominant connectivity type in the Gresham East Buttes area were braided linkages. Current values ranged between $0-2.48$ with a skewed distribution.

\section{Criteria 2: Habitat Score}

The habitat score describes the proportion of species-specific habitat characteristics available within a HCZ. I followed the Metro Regional Habitat Toolkit Methods (Chapter 2) to score habitat quality across the Gresham East Buttes forty habitat connectivity zones. Habitat quality scores for 34 habitat characteristics were generated using the Northern Red-legged Frog species scorecard (Appendix B: Forms). Habitat scores were presented as the percentage combined score, containing the sum of GIS and field collected data, out of the total potential habitat score. The habitat scores were 
mapped using a 4-class geometric interval (Figure 12). The overall habitat quality scores ranged from $39 \%$ to $70 \%$.

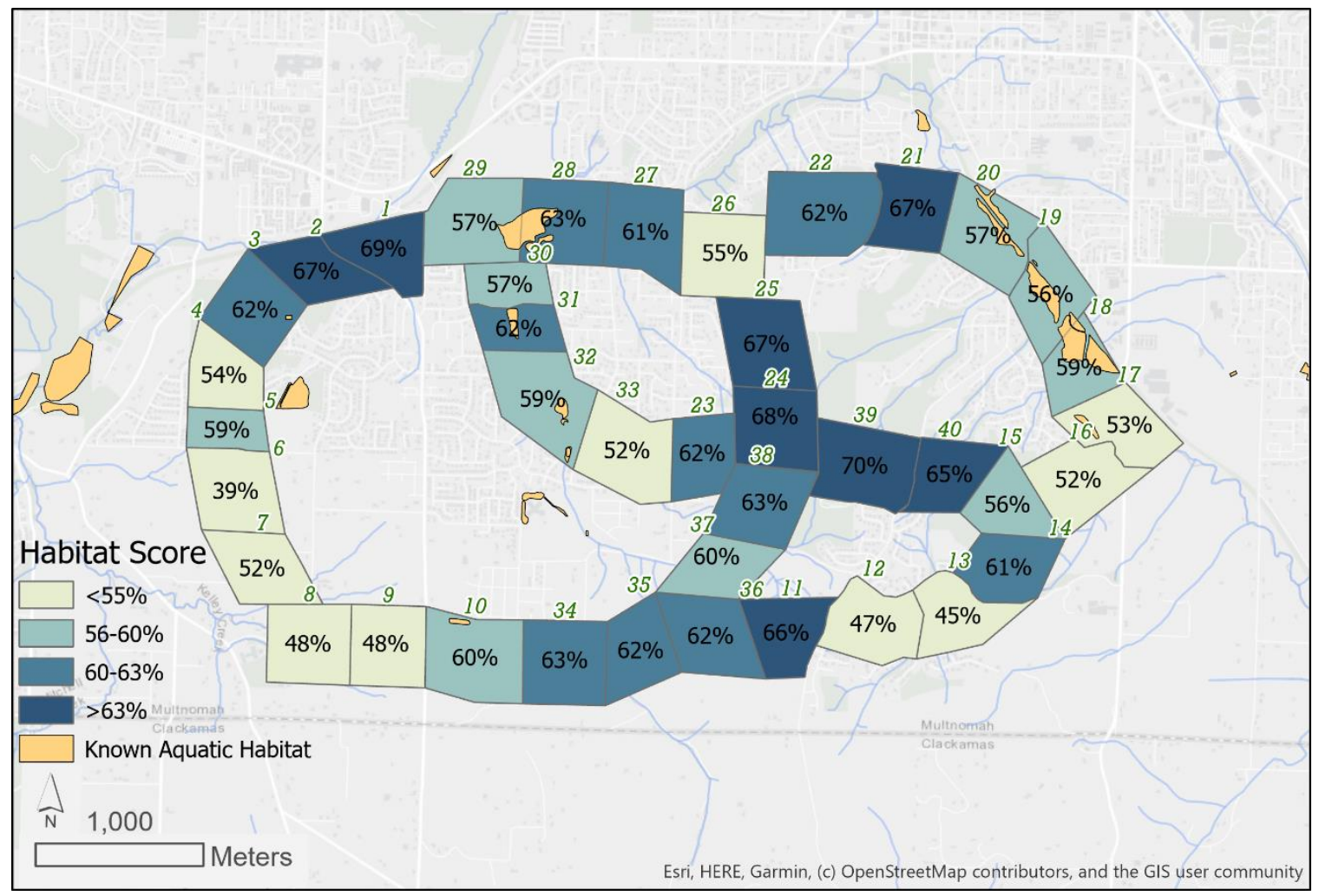

Figure 12. Criteria 2: Metro Toolkit Habitat Quality Score

Each Habitat connectivity zone (HCZ) in the Gresham East Buttes area was given calculated habitat scores using the Metro Regional Habitat Connectivity Toolkit and Northern Red-legged Frog scorecard, representing the quality and availability of habitat for wildlife moving across the predictive pathway.

The East pathway-Hogan Butte average habitat score was 50\% and two adjacent zones (HCZ 16=52\% and 17=53\%) were low scoring. These two zones are separated by Hogan Avenue, adjacent to forested Hogan Butte Park, Cedar Lake, and Ambleside along the Springwater corridor trail. There are open canopy gaps to the south within the pathway and industrial areas along the eastern boundary. To the west are residential neighborhoods. The West pathway which is agricultural-dominant had an average habitat 
score of $17 \%$. The west pathway starts to the south of Jenne Butte Park and southeast of Powell Butte. It ends along Kelley Creek west of Brookside Greenway.

Criteria 3: Aquatic and Terrestrial Habitat

Amphibian presence/absence in aquatic habitats between 2007-2015 were organized into a database and filtered by locations with presence of $R$. aurora egg masses The data sets compiled were from Johnson Creek Surveys (2007-2015, value='1') and Gresham Amphibian Surveys (2008, value= '1'). City of Portland Powell Butte Surveys (2010) conducted on the western edge of the East Buttes extent were also included for context only. Polygon features of waterbodies, wetlands, stormwater facilities, and tax lots containing water sources were aggregated across an eight-year period when $R$. aurora egg masses, larvae, or adults (any abundance) were detected even once at survey sites. Occupancy and abundance data across sites and years were available through the egg mass survey databases but were not used for connectivity modeling applications in the scope of this research.

To describe the urban terrestrial vegetation within predicted connectivity pathways, I measured the straight-line distances from known aquatic sites to 5-acre core terrestrial areas using tools in ArcMap 10.6x. The East buttes standards for wildlife protections and management follow a minimum forest patch size guideline of 30 acres in size to protect biodiversity and sensitive species (Gabbert Butte Nature Park Master Plan 2019). The core size I selected, 5 acres is appropriate for an urban area, but is smaller than guidelines as well as other urban amphibian habitat recommendations which ranged 
between 10 and 130 acres in size (10 to 50 acres-Baldwin, Calhoun, and deMaynadier 2006; 10-130 acres- Beninde, Veith, and Hochkirch 2015). I did not consider the distance to smaller terrestrial or aquatic habitat patches between the surveyed aquatic sites and 5-acre terrestrial cores, which may act as stepping stone connectivity for frogs (Fahrig 2003). Even if core terrestrial patches are available, the frogs may not travel far distances to reach them when smaller urban, agricultural, or industrial areas have adequate moisture and vegetative cover. This is why spatially explicit models that consider connective stepping stone habitat rather than core patch sizes may be best suited for frogs in urbanizing areas.

The 2018 Oregon State Wide Habitat Map (PSU-INR) was reclassified to values of one representing suitable terrestrial habitat, and zero representing minimal potential as R. aurora terrestrial habitat (Appendix C: Additional Data). The ArcMap 10.6x focal statistics tool was used for a moving window analysis on the reclassified State Wide Habitat remap to determine core terrestrial habitat availability. The percent core terrestrial habitat areas were determined based on the availability of 5-acre minimums with $100 \%$ core values within the pathway. Values with $100 \%$ core habitat within each pathway were extracted using the extract by mask tool. The proximity toolset, near tool (search distance 1000 meters), was used to find minimum and maximum distances between known aquatic habitat and core terrestrial habitat. Aquatic sites within 100 meters of a terrestrial core represent adjacency between aquatic-terrestrial connections, and aquatic sites between 100-1000 meters away from terrestrial cores were assumed to 
require $R$. aurora movement across the surrounding landscape matrix (i.e. urban or agriculture) to access these habitat cores.

There were 24 records of surveyed aquatic habitats including wetlands and stormwater ponds within the Gresham East Buttes study site extent. Aquatic habitat sites were polygon shapefiles comprised of wetland boundaries, NWI polygons, and tax lots containing stormwater ponds or detention facilities. I removed duplicate records by aggregating aquatic sites with the same name or site ID and identified 18 unique records of known aquatic habitats with presence of R. aurora surveyed between 2007-2013 (Figure 13). 


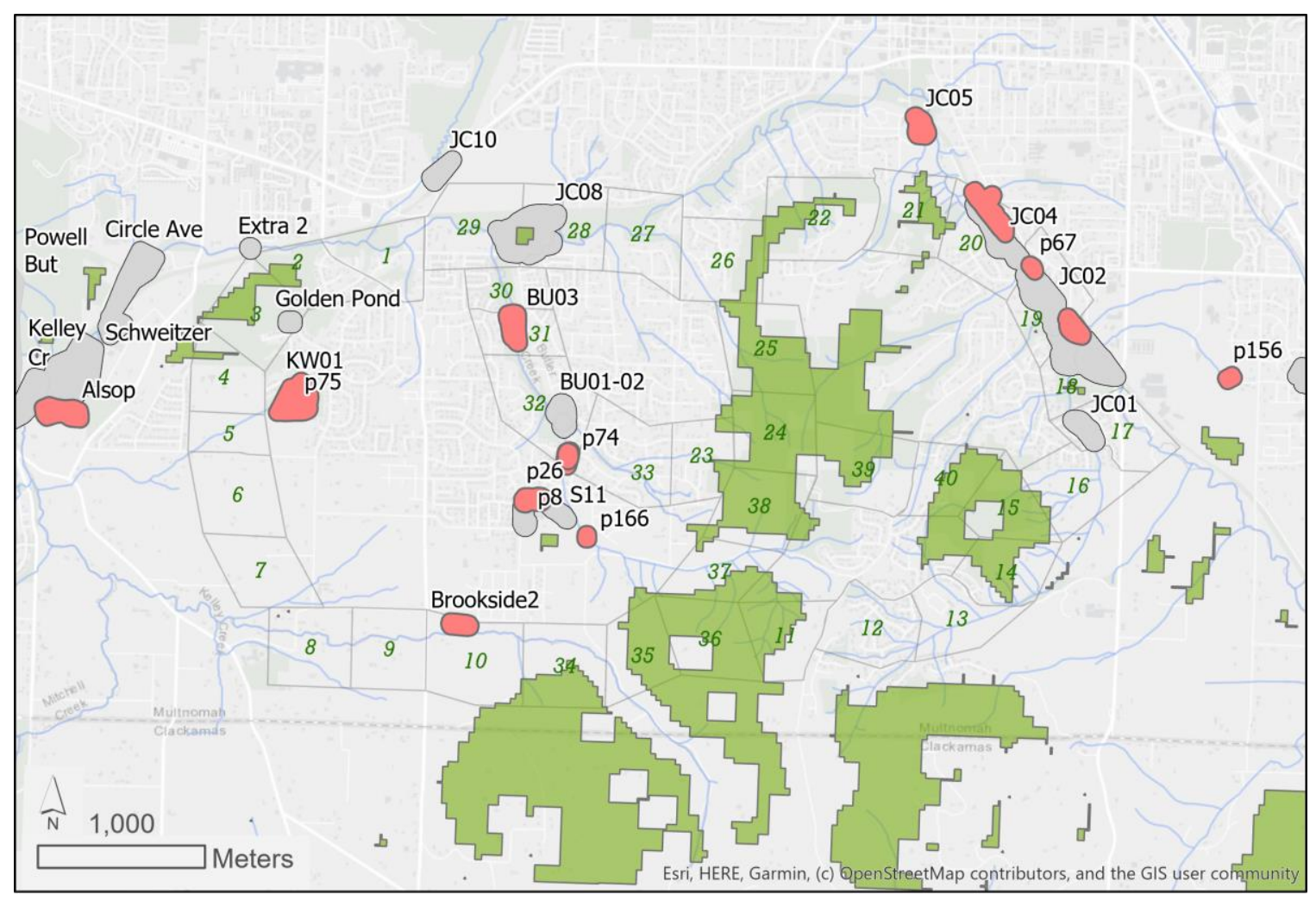

\section{Distance Aquatic-Terrestrial Habitat}

Core Terrestrial Habitat 5 acres

Aquatic Habitat $<100$ meters

Aquatic Habitat $>100$ meters

Figure 13. Criteria 3: Aquatic and Terrestrial Habitat

There were 24 individual records of known aquatic habitats in the Gresham East Buttes region study area with Northern Red-legged frog occupancy collected from City of Gresham and Johnson Creek watershed amphibian egg-mass monitoring surveys conducted between 2007-2015 by local managers and volunteers.

I first excluded known aquatic habitats and core terrestrial habitat outside of the predicted connectivity pathway boundaries. The central 1 , central 3 , and west pathways did not have presence of $R$. aurora at known aquatic sites. Central 1 and Central 3 pathways are between a forested chain of buttes with an old logging road and trail systems between them. These pathways have headwaters for nearby streams. There were no known or potential amphibian survey sites at the time the survey data was collected 
here. However, just to the east of the two pathways was a newly discovered pristine pond containing numerous $R$. aurora egg masses which were found near the proposed parking lot entrance during the development of the Gabbert Butte trail network and nature park 2018-2019 (personal correspondence, K. Holzer). Small stormwater ponds and newly built or restored ponds have yet to be completely identified and surveyed. The west pathway which is agricultural dominant did not have known aquatic breeding habitats. This agricultural area has open spaces and minimal tree canopy or riparian forests. However, just outside of our study area extent to the west are the Jenne Butte trails which connect to wide open wetlands surrounded by light residential areas. There are reed-filled lowland areas that contain $R$. aurora egg masses.

In summary, the connectivity current values ranged between 0.28 to 2.48 and were predominantly braided linkages (Table 3). Pinch-points were locally constrained to narrow riparian areas surrounded by residential development such as along Butler Creek, or along major roads such as SE Towle Avenue and SE $190^{\text {th }}$ Avenue. The connectivity values are species, site, and scale specific. There are limitations to Circuitscape models. The results are often difficult to interpret because values are scaled by least resistance (least energetically taxing or shortest distance), density, or by the number of overlapping movement paths in the model results. Depending on node placement, data type, accuracy, resolution of the resistance raster, similarly sized pathways may contain many different connectivity values (Koen et al. 2014). Selecting and prioritizing connectivity pathways to manage for within the bounds of specific conservation goals or budgets becomes increasingly important (McRae et al. 2008; Wade, McKelvey, and Schwartz 
2015). For Circuitscape, the connectivity values represent an aggregate of all possible crossings at any given time frame and is directly dependent on the species-specific resistance raster assigned (Sutherland et al. 2014). Connectivity tools like Circuitscape have pathway bias which can come from placing start and end locations selectively (i.e. source and ground nodes or areas of interest) on the landscape, such as the case of the four butte nodes utilized in this project.

The overall, combined habitat quality scores ranged from $39 \%$ to $70 \%$. Zone specific management is recommended along low scoring habitat connectivity zones along each of the seven pathways, as the average habitat score does not include permeability scores or fine-scale information within and between connected HCZ (i.e. connections between aquatic and terrestrial habitat). Distance-area to forest cover played an important role for R. aurora occupancy predictions in urbanizing environments (Guderyahn, Smithers, and Mims 2016, Grand et al. 2017). The distances between aquatic habitat and five acre core terrestrial habitats in the connective pathways predicted for the Gresham East Buttes ranged directly adjacent, or 0 meters away (i.e site JC08/HCZ 28-29), to a maximum distance of 395 meters away (site p74/HCZ 32-33). The mean distances between aquatic and terrestrial habitat were 132 meters apart within the study area extent. Only one aquatic site (BU02) was greater than 500 meters from a terrestrial core. The association between other distance-core area relationships, patchy or stepping-stone habitat spatial arrangements should be explored in the future. 
Table 3. Priority Connectivity in Gresham East Buttes, Oregon

An example application of criteria appropriate for Northern Red-legged Frog habitat connectivity management in urban environments and the results come from the Gresham East Buttes surveys from 2018. This is a quantitative assessment of habitat quality using both GIS and field methods (as a combined score).

\begin{tabular}{|c|c|c|c|c|}
\hline $\begin{array}{c}\text { Pathway } \\
\text { Name }\end{array}$ & Description & $\begin{array}{c}\text { Connectivity } \\
\text { Type }\end{array}$ & $\begin{array}{l}\text { Habitat } \\
\text { Score }\end{array}$ & $\begin{array}{c}\text { Aquatic and } \\
\text { Terrestrial Habitat }\end{array}$ \\
\hline \multicolumn{5}{|c|}{ Priority Connectivity Pathways } \\
\hline Central 2 & Butler Creek & $\begin{array}{l}\text { Braided } \\
\text { Min }<1.0 \\
\text { Max } 0.68 \\
\text { Average } 0.02 \\
\text { Local pinch } \\
\text { points } \\
\text { Butler Creek } \\
\text { Riparian } \\
\text { corridor } \\
\text { Residential }\end{array}$ & $\begin{array}{l}\text { Range } \\
52-62 \% \\
\\
\text { Average } \\
58 \%\end{array}$ & $\begin{array}{l}\text { Aquatic site in pathway: } \\
\text { Butler Creek Park, Binford Lake } \\
<1000 \mathrm{~m} \text { south of pathway } \\
\text { Butler Creek Elementary } \\
\text { Terrestrial 5-acre core: } \\
2.40 \% \text { potential terrestrial habitat } \\
\text { Minimum distance to aquatic site } \\
0 \mathrm{~m} \text {, within pathway on east edge, next } \\
\text { nearest core habitat } 100-400 \mathrm{~m} \text { from } \\
\text { pathway }\end{array}$ \\
\hline South & $\begin{array}{l}\text { South } \\
\text { Multnomah } \\
\text { county } \\
\text { boundary }\end{array}$ & $\begin{array}{l}\text { Sheet flow } \\
\text { Min }<1.0 \\
\text { Max } 0.29 \\
\text { Average } 0.02 \\
\text { Braided East } \\
\text { with low } \\
\text { values } \\
\text { Augusta Loop } \\
\text { riparian } \\
\text { Residential }\end{array}$ & $\begin{array}{l}\text { Range } \\
45-66 \% \\
\\
\text { Average } \\
57 \%\end{array}$ & $\begin{array}{l}\text { Aquatic site in pathway: } \\
\text { Brookside pond } \\
<1000 \mathrm{~m} \text { from pathway Butler Creek } \\
\text { Elementary } \\
\text { Terrestrial } 5 \text {-acre core: } \\
30.94 \% \text { potential terrestrial habitat } \\
\text { Minimum distance to aquatic site: } \\
0 \mathrm{~m} \text {, within pathway, next nearest core } \\
\text { habitat } 100-400 \mathrm{~m} \text { from pathway }\end{array}$ \\
\hline West & Agricultural & Braided & $\begin{array}{l}\text { Range } \\
39-59 \%\end{array}$ & $\begin{array}{l}\text { Aquatic site in pathway: } \\
\text { None }\end{array}$ \\
\hline
\end{tabular}




\begin{tabular}{|c|c|c|c|c|}
\hline & & $\begin{array}{l}\text { Min }<1.0 \\
\text { Max } 1.41 \\
\text { Average } 0.05 \\
\text { Local pinch } \\
\text { points } \\
\text { Kelley Creek } \\
\text { Riparian area } \\
\text { and } \\
\text { SE 190th ave } \\
\text { Rural } \\
\text { Agricultural }\end{array}$ & $\begin{array}{l}\text { Average } \\
50 \%\end{array}$ & $\begin{array}{l}<1000 \text { m from pathway } \\
\text { Jenne Butte Park, Kelley Creek } \\
\text { Terrestrial 5-acre core: } \\
0.67 \% \text { potential terrestrial habitat } \\
\text { Minimum distance to aquatic site: } \\
0 \text { m within pathway, next nearest core } \\
\text { habitat } 400-1000 \text { m from pathway }\end{array}$ \\
\hline \multicolumn{5}{|c|}{ Other Connectivity Pathways } \\
\hline North & $\begin{array}{l}\text { Johnson } \\
\text { Creek, } \\
\text { Springwater } \\
\text { Corridor Trail }\end{array}$ & $\begin{array}{l}\text { Braided } \\
\text { Min }<1.0 \\
\text { Max } 1.71 \\
\text { Average } 0.05 \\
\text { Local pinch } \\
\text { points } \\
\text { Towle Ave and } \\
\text { Pleasant View } \\
\text { Drive } \\
\text { Residential, } \\
\text { mixed use }\end{array}$ & $\begin{array}{l}\text { Range } \\
55-69 \% \\
\text { Average } \\
62 \%\end{array}$ & $\begin{array}{l}\text { Aquatic site in pathway: } \\
\text { Springwater Corridor Trail Ponds, Golden } \\
\text { Pond } \\
<1000 \mathrm{~m} \text { from pathway } \\
\text { Gresham-Fairview Trail Pond, Circle Ave } \\
\text { Pond, Powell Butte Ponds } \\
\text { Terrestrial 5-acre core: } \\
9.40 \% \text { potential terrestrial habitat } \\
\text { Minimum distance to aquatic site: } \\
0 \text { m surrounding pond, next nearest core } \\
\text { habitat: } 100-300 \mathrm{~m} \text { from pathway }\end{array}$ \\
\hline East & Hogan Butte & $\begin{array}{l}\text { Braided } \\
\text { Min }<1.0 \\
\text { Max } 0.60 \\
\text { Average } 0.04 \\
\text { Residential, } \\
\text { mixed use }\end{array}$ & $\begin{array}{l}\text { Range } \\
52-59 \% \\
\text { Average } \\
55 \%\end{array}$ & $\begin{array}{l}\text { Aquatic site in pathway: } \\
\text { Hogan Butte Wetlands and Ponds } \\
<1000 \mathrm{~m} \text { from pathway } \\
\text { Wetland conservancy site, small } \\
\text { stormwater ponds } \\
\text { Terrestrial 5-acre core: } \\
1.15 \% \text { potential terrestrial habitat } \\
\text { Minimum distance to aquatic site: } \\
0 \mathrm{~m} \text {, surrounding pond, next nearest core } \\
\text { habitat: 100-200 m from pathway }\end{array}$ \\
\hline
\end{tabular}




\begin{tabular}{|c|c|c|c|c|}
\hline Central 1 & $\begin{array}{l}\text { Gresham- } \\
\text { Gabbert Butte }\end{array}$ & $\begin{array}{l}\text { sheet flow } \\
\text { Min }<1.0 \\
\text { Max } 2.488 \\
\text { Average } 0.09 \\
\text { Forested } \\
\text { park } \\
\text { Residential }\end{array}$ & $\begin{array}{l}\text { Range } \\
60-68 \% \\
\text { Average } \\
64 \%\end{array}$ & $\begin{array}{l}\text { Aquatic site in pathway: } \\
\text { None } \\
<1000 \text { m north and west of pathway Butler } \\
\text { Creek Elementary, Springwater corridor } \\
\text { trail ponds, stormwater ponds } \\
\text { Terrestrial 5-acre core: } \\
63.77 \% \text { potential terrestrial habitat } \\
\text { Minimum distance to aquatic site: } \\
\text { 0, within pathway, next nearest core } \\
\text { habitat: 6--700 m from pathway }\end{array}$ \\
\hline Central 3 & $\begin{array}{l}\text { Gabbert- } \\
\text { Hogan Butte }\end{array}$ & $\begin{array}{l}\text { Sheet flow } \\
\text { Min }<1.0 \\
\text { Max } 1.20 \\
\text { Average } 0.04 \\
\text { Forested } \\
\text { park, some } \\
\text { Residential }\end{array}$ & $\begin{array}{l}\text { Range } \\
56-70 \% \\
\text { Average } \\
63 \%\end{array}$ & $\begin{array}{l}\text { Aquatic site in pathway: } \\
\text { None } \\
<1000 \text { m east of pathway } \\
\text { SE Vista way pond, Hogan Butte ponds, } \\
\text { Springwater corridor } \\
\text { Terrestrial 5-acre core: } \\
47.97 \% \text { potential terrestrial habitat } \\
\text { Minimum distance to aquatic site: } \\
0 \text { m, within pathway, next nearest core } \\
\text { habitat: } 400-600 \text { m from pathway }\end{array}$ \\
\hline
\end{tabular}




\section{Chapter 5}

Conclusions and Future Research Recommendations

\section{Conclusions}

The conservation efforts and connectivity strategies put forward by the Northern Red-legged Frog (Rana aurora) case studies presented in this research project may benefit other wildlife species who exhibit this fine-scale aquatic-terrestrial connectivity and share similar survival risks in highly developed environments. A potential issue for the species scorecard system can arise if landscape assumptions are incorrect, such as assigning low habitat quality values to urban water sources instead of high values for its vital role as functional breeding habitat in urbanized parts of the region (Holzer 2014). Additionally, missing or misclassified data will influence habitat quality scores. GIS data are limited by data accuracy, user-defined biological-environmental parameters, and availability of wildlife tracking or monitoring data for validation. However, GIS and field derived data contribute unique information which can be collected simultaneously using analytical toolkits like the Metro Regional Habitat Connectivity Toolkit.

The Gresham East Buttes is not a unique site, it's patchy mixed hardwood-conifer forest cover, wetland restoration sites, and development dominant streams and stormwater ponds can be found across growing cities. GIS data such as forest structure, water seasonality, or topography derived from land cover data requires aerial or field verification for accuracy assessment but may be too expensive and not fine-scale enough to capture habitat patches and transitions occurring in urbanizing environments. Therefore, a combination of GIS and field derived data is a necessity for promoting 
accurate and comparable indices that inform management decisions in heterogenous and rapidly transforming landscapes.

\section{Future Research Recommendations}

\subsection{Monitoring Amphibian Habitat and Movement}

Many amphibian populations go locally extinct, sometimes decades after land use alteration (Brum et al. 2013; Goldspiel et al. 2019). However, there are egg mass survey datasets which are recorded annually for many pond-breeding amphibian species, especially at high priority conservation sites within Multnomah County (City of Portland, City of Gresham). The rich abundance and occupancy data collected here could be used to extrapolate environmental parameters that affect breeding-site selection and maximum migration distances in urban areas (Guderyahn et al. 2016). Forest cover surrounding aquatic sites have predictive importance for enhancing adult habitat quality in this region (Grand et al. 2017, Rowe et al. 2019). The newest residential stormwater and retrofit strategies set in future urban developments may be target connectivity monitoring sites for researching effects of urban construction on movement behavior and population establishment in new parts of the metropolitan region (City of Gresham- Stormwater Retrofit Strategy and Plan 2014). These findings would direct connectivity restoration and mitigation priorities toward places where $R$. aurora can access aquatic and terrestrial habitats within reasonable distance from newly established breeding sites.

More information about the adult terrestrial habitat and movement distances from their aquatic habitat is still needed in urbanizing areas. Additionally, there is a need to 
better study distances to terrestrial structures such as small, isolated, distance vegetative patches to find minimum patch size requirements (Holzer 2014; Guderyahn, Smithers, and Mims 2016). Harborton Frog shuttle efforts are the only target barrier mitigation strategy implemented for $R$. aurora migration in the region. Tracking can also validate how culverts, trails, fences, sound and noise barriers that are inherently built into our urban landscapes may affect frog movement permeability. Urban connectivity gaps may be acting differently than open forest gaps because there are remnant habitats along roadways and residential yards (Chan-McLeod and Moy 2007). It is possible that many urban features may be utilized during terrestrial migrations of $R$. aurora. By incorporating sword ferns, moisture retaining vegetation, and burrowing substrates within R. aurora aquatic-terrestrial connectivity ranges we may improve movement permeability to and from aquatic breeding sites (Guderyahn 2019).

Other research tools like genetics and translocations are being explored to supply new information for preliminary Metro Toolkit and Circuitscape connectivity models, as well as informing how $R$. aurora adapt to changing urbanization conditions. Landscape and population genetics research covers long-term or historical dispersal events modeled for R. aurora (personal correspondence L. Chan, Watts et al. 2015). Translocations of frog embryos and adult frogs is done experimentally and accidentally, transferring genetically distinct populations across the region (Ostergaard, Richter, and West 2008). These studies provide insight into the adaptability of frogs to novel environments like a highly urbanized one. Newly transformed areas, such as suburban developments or restored wetlands are targets for introducing translocated frogs. As the availability of 
artificial water sources are increasingly integrated into urban planning, habitat connectivity will provide the frogs with protected access to their terrestrial environments.

Seasonality and migration periods affect movement behaviors and should also be integrated into future scorecards and weighting schemes. For example, juvenile and adult Northern Red-legged Frog daily movement behaviors are sensitive to cover, moisture, and temperature changes. These behaviors range from highly mobile to stationary, and it is possible that during highly mobile phases, such as migrations to and from breeding sites, roads may have more of a barrier-like impact (Vos and Chardon 1998). Additionally, fine habitat features may not be recorded using the broad habitat characteristics from habitat assessment surveys. Rana aurora are found under 365 meters of elevation in upland mixed-conifer mature forests (Aubry 2000; Hayes et al. 2008). During the overwintering and summer movement phases these frogs use vegetation or debris to retain moisture and remain motionless using cryptic camouflage. Active movement typically occurs at nighttime during rainfall or when the frog is disturbed by outside activity like an approaching surveyor or predatory threat (Schuett 2004 and personal correspondence Harborton Shuttle Volunteers). Active movement is also driven by shifts in moisture availability, especially during the summer. In urban environments private and backyard habitats can be very important. Frogs are found in open canopy, grasses, flower gardens, and even in residential compost piles that retain surface moisture during drought periods (Schuett 2004 and personal correspondence L. Guderyahn). Rana aurora are also found along forest edges, crossing recent clear cuts and open gaps (ChanMcLeod and Moy 2007). Rana aurora diet consists of soil-based arthropods, mollusks, 
and salamanders that share $R$ aurora's preference for multi-layered vegetative structure, and moist decaying materials as part of their habitat (Rabinowe et al. 2002). Identifying limiting factors for Rana aurora habitat is complicated due to these seasonal, and urban adaptations at different life stages.

\subsection{Urban Habitat Connectivity Management}

There are unknown factors affecting overwintering and summer terrestrial movements and seasonal connectivity between ephemeral wetlands and dense upland forest habitats (Becker et al. 2007). In terms of occurrence in the Portland Metropolitan region, studies indicate there is no clear negative associations between numbers of $R$. aurora with presence of non-native bullfrogs or invasive vegetation in urbanizing stormwater ponds (Holzer 2014; Guderyahn, Smithers, and Mims 2016). However, reconnecting aquatic-terrestrial habitats within developed urban and agricultural areas could potentially spread disease, sedimentation, pollutants, and invasive species (Jackson and Pringle 2010; Haddad et al. 2014; Clevenot, Carré, and Pech 2018). Urban environmental stresses due to limited, low quality, or fragmented habitat may see some unintended connectivity risks. Connectivity strategies should address potential risks but not diminish the value of restoring and maintaining habitat connectivity in the region.

There is also predictive uncertainty in applying landscape connectivity because of shifting climate and land use changes (Fischer and Lindenmayer 2007; Lindenmayer et al. 2008). Therefore, conservation management tools must incorporate temporal components and represent multi-dimensionality of regional species and habitat types. 
Much more information on comparisons and interpretation of habitat suitability and connectivity tools can be reviewed prior to selecting a region-wide method (Poor et al. 2012; Rudnick et al. 2012; Rose 2013; Pelletier et al. 2014; Wade, McKelvey, and Schwartz 2015; Nordén 2016; Naidoo et al. 2018; Zeller et al. 2018).

Defining model connectivity type for amphibians presents a different challenge from large migrating species. It is not certain whether habitat or connectivity models can capture the fine-scale movements that occur. There is uncertainty in how far R. aurora travel seasonally, how regularly they use the same pathways, and how broad spanning their home ranges are in both natural and urbanizing environments. In the applications chapter the Circuitscape model establishes preliminary habitat connectivity zones, and pathways optimal for $R$. aurora connectivity. However, these pathways were delineated using preliminary species models and an analytical toolkit. By establishing criteria such as connectivity type, habitat quality, and monitoring data, conservation managers can direct future sampling and field validation efforts toward priority pathways. As urbanization increases, terrestrial habitat models that predict tax lot changes, understory vegetation, surface depressions, potential wetland soils, and hydroperiod are helpful additions to urban connectivity models because land use changes like new developments may replace critical pond and wetland habitats in a short period of time.

The Portland Metropolitan area has local management recommendations nested beneath federal requirements to serve multiple purposes such as: to protect wildlife, habitat corridors, vegetation buffers, agricultural runoff, and water quality. Typically 100-300 ft of a potential $R$. aurora aquatic habitat site are managed or protected in some 
form, but this is not nearly enough to protect functional connectivity requirements in the area based on the known distances (up to $5 \mathrm{~km}$ ) $R$. aurora can travel to reach terrestrial overwintering and summer habitat (Metro 2006, City of Portland 2009, City of West Linn 2014, Oregon Department of Agriculture 2018). Compensatory mitigation requirements are also too low to protect $R$. aurora migrations. The EPA clean water act (U.S. Environmental Protection Agency Clean Water Act Section 404) propose minimum buffers which are often 50 to 200 feet away from water sources and is not enough. We do know that $R$. aurora utilize stormwater ponds and patchy vegetation cover far from water. These are not fully protected areas and could represent stepping stones for $R$. aurora migration. Consideration for extending habitat connectivity management beyond the Gresham East Buttes, such as across county Multnomah-Clark county lines, and between natural and urbanizing areas can be driven by management plans like those outlined in the Gabbert Butte Master Plan (Gabbert Butte Nature Park Master Plan 2019). By linking the East Buttes area to the southern natural areas outside of the study extent we can incorporate additional amphibian connectivity on a landscape scale.

Other connectivity tools are emerging that will supply more information to preliminary connectivity map results. Circuit theory and graph theoretic are popular approaches to connectivity on a natural landscape scale but may not apply to amphibianscales which rely on smaller structural components that may be underrepresented or difficult to find in urban areas. One tool, Omniscape takes a similar approach to Circuitscape by using circuit connectivity to provide multiple linkage options at varying scales. It has faster processing time with advancements in visualizing connectivity at 
many scales. Omniscape does not require defined core areas or specifically placed corridor linkages to contextualize continuous landscape connectivity (McRae et al. 2016; Dickson et al. 2019). In general connectivity tools have also been used in transportation planning, fire management, and development which should be considered across statewide and multiple species connectivity strategies (Choe and Thorne 2019).

Several other approaches besides habitat and connectivity modeling have been used to research and visualize the movement of these frog's movement or dispersal ranges. Modeling movement using random walk have been used in behavioral studies for R. aurora juvenile dispersal which exhibits opportunistic and random directions or distances in order to occupy less-risky habitat free from density, predation, or desiccation. Some cognitive memory may be expected for adult frogs with migratory experience, in which frogs may utilize pathways they've retained from previous seasons. There are a number of tools land managers can integrate into their regional habitat connectivity strategies, but it all starts with regional and site-scale proposals for priority connectivity where we can test the model's capabilities and limitations for different habitat types. 
References

Alford, R., and J. Rowley. 2007. Techniques for tracking amphibians: The effects of tag attachment, and harmonic direction finding versus radio telemetry. Amphibia-Reptilia 28 (3):367-376.

Anderson, M. G., A. Barnett, M. Clark, J. Prince, A. Olivero Sheldon, and B. Vickery. 2016. Resilient and Connected Landscapes for Terrestrial Conservation. The Nature Conservancy, Eastern Conservation Science, Eastern Regional Office. Boston, MA.

Angold, P. G., J. P. Sadler, M. O. Hill, A. Pullin, S. Rushton, K. Austin, E. Small, B. Wood, R. Wadsworth, R. Sanderson, and K. Thompson. 2006. Biodiversity in urban habitat patches. Science of The Total Environment 360 (1):196-204.

Aubry, K. B. 2000. Amphibians in Managed, Second-Growth Douglas-Fir Forests. The Journal of Wildlife Management 64 (4):1041-1052.

Baldwin, R. F., A. J. K. Calhoun, and P. G. deMaynadier. 2006. Conservation Planning for Amphibian Species with Complex Habitat Requirements: A Case Study Using Movements and Habitat Selection of the Wood Frog Rana sylvatica. Journal of Herpetology 40 (4):442-453.

Beier, P., W. Spencer, R. F. Baldwin, and B. H. Mcrae. 2011. Toward Best Practices for Developing Regional Connectivity Maps, Hacia Mejores Prácticas para Desarrollar Mapas de Conectividad Regional. Conservation Biology 25 (5):879-892.

Beller, E. E., E. N. Spotswood, A. H. Robinson, M. G. Anderson, E. S. Higgs, R. J. Hobbs, K. N. Suding, E. S. Zavaleta, J. L. Grenier, and R. M. Grossinger. 2019. Building Ecological Resilience in Highly Modified Landscapes. BioScience 69 (1):80-92.

Beninde, J., M. Veith, and A. Hochkirch. 2015. Biodiversity in cities needs space: a meta-analysis of factors determining intra-urban biodiversity variation ed. N. Haddad. Ecology Letters 18 (6):581-592.

Bliss-Ketchum, L. L., C. E. de Rivera, B. C. Turner, and D. M. Weisbaum. 2016. The effect of artificial light on wildlife use of a passage structure. Biological Conservation 199:25-28.

Bliss-Ketchum, et. al. n.d. Working Title-Species Scorecard Selection. In Progress for Publication. 
Bond, M. L., C. M. Bradley, C. Kiffner, T. A. Morrison, and D. E. Lee. 2017. A multimethod approach to delineate and validate migratory corridors. Landscape Ecology 32 (8):1705-1721.

Bredeweg, E. M., J. Urbina, A. T. Morzillo, and T. S. Garcia. 2019. Starting on the Right Foot: Carryover Effects of Larval Hydroperiod and Terrain Moisture on Postmetamorphic Frog Movement Behavior. Frontiers in Ecology and Evolution 7 (97).

Brum, F. T., L. o. Goncalves, L. Cappelatii, M. B. Carlucci, V. J. Debastiani, E. V. Salengue, G. D. dos S. Seger, C. Both, J. S. Bernardo-Silva, R. D. Loyola, and L. da S. Duarte. 2013. Land Use Explains the Distribution of Threatened New World Amphibians Better than Climate. PLOS ONE 8 (4).

Bulger, J. B., N. J. Scott, and R. B. Seymour. 2003. Terrestrial activity and conservation of adult California red-legged frogs Rana aurora draytonii in coastal forests and grasslands. Biological Conservation 110 (1):85-95.

Bunnell, C., F. Bunnell, A. Baylis, A. R. Canada, C. Juteau, and A. R. Canada. 2016. Long-term monitoring of northern red-legged frog in the Little Campbell River watershed-2009-2014. A Rocha Canada Conservation Science Series :40.

Campbell, L. M. 2000. Human need in rural developing areas: perceptions of wildlife conservation experts. The Canadian Geographer/Le Géographe canadien 44 (2):167181.

Chan-McLeod, A. C. A., and A. Moy. 2007. Evaluating Residual Tree Patches as Stepping Stones and Short-Term Refugia for Red-Legged Frogs. The Journal of Wildlife Management 71 (6):1836-1844.

Choe, H., and J. H. Thorne. 2019. Omnidirectional connectivity of urban open spaces provides context for local government redevelopment plans. Landscape and Ecological Engineering 15 (3):245-251.

Christy, J. A., and E. R. Alverson. 2011. Historical Vegetation of the Willamette Valley, Oregon, circa 1850. Northwest Science 85 (2):93-107.

City of Gresham

2003. Water Quality Manual. Last Accessed 18 November 2019 at

https://greshamoregon.gov/Watershed-Documents-and-Forms/

2005. Johnson Creek Basin Stormwater Master Plan including Springwater and Pleasant Valley Areas. 2005.

Last Accessed 18 November 2019 at https://greshamoregon.gov/WorkArea/DownloadAsset.aspx?id=5629. 
City of Gresham

2014. Stormwater Retrofit Strategy and Plan.

Last Accessed 18 November 2019 at

https://greshamoregon.gov/WorkArea/DownloadAsset.aspx?id=5629.

City of Portland, Bureau of Environmental Planning 2009. Willamette River Natural Resource Inventory Report: Riparian Corridors and Wildlife Habitat. Last Accessed 3 October 2019 at https://www.portlandoregon.gov/bps/article/158893

2018. 2035 Comprehensive Plan. Last Accessed 18 November 2019 at https://www.portlandoregon.gov/bps/2035-comp-plan.pdf

City of Portland, Portland Parks and Recreation 2011. Forest Park Desired Future Condition. Last Accessed 18 November 2019 at https://www.portlandoregon.gov/parks/article/335638

City of West Linn Tualatin River TMDL Implementation Plan 2014-2019. Revised 2014. Last Accessed 20 November 2019 at https://westlinnoregon.gov/sites/default/files/fileattachments/public_works/page/9143/tua latin_river_tmdl_implementation_plan_final.pdf

Clark, J. D., Jared S. Laufenberg, Maria Davidson, and Jennifer L. Murrow. 2015. Connectivity among subpopulations of Louisiana black bears as estimated by a step selection function. Journal of Wildlife Management 79 (8):1360.

Dickson, B. G., C. M. Albano, R. Anantharaman, P. Beier, J. Fargione, T. A. Graves, M. E. Gray, K. R. Hall, J. J. Lawler, P. B. Leonard, C. E. Littlefield, M. L. McClure, J. Novembre, C. A. Schloss, N. H. Schumaker, V. B. Shah, and D. M. Theobald. 2019. Circuit-theory applications to connectivity science and conservation. Conservation Biology 33 (2):239-249.

Dobson, N. G., and A. R. Gilroy. 2009. From Partnership to Policy: The Evolution of Active Living by Design in Portland, Oregon. American Journal of Preventive Medicine 37 (6, Supplement 2):S436-S444.

Downs, J. A., and M. W. Horner. 2012. Enhancing Habitat Connectivity in Fragmented Landscapes: Spatial Modeling of Wildlife Crossing Structures in Transportation Networks. Annals of the Association of American Geographers 102 (1):17-34.

Drake, J. C., K. Griffis-Kyle, and N. E. McIntyre. 2017. Using nested connectivity models to resolve management conflicts of isolated water networks in the Sonoran Desert. Ecosphere 8 (1). 
Evans, D. M., N. E. Turley, D. J. Levey, and J. J. Tewksbury. 2012. Habitat patch shape, not corridors, determines herbivory and fruit production of an annual plant. Ecology 93 (5):1016-1025.

Evans, J. 2007. Wildlife Corridors: An Urban Political Ecology. Local Environment 12 (2):129-152.

Faccio, S. D., S. W. MacFaden, and E. W. Buford. 2019. Where do salamanders cross the road? Development of a GIS model to identify amphibian road-crossing hotspots. Vermont Agency of Transportation. Last Accessed 18 November 2019 at https://doi.org/10.6084/m9.figshare.7754930.v1

Fahrig, L. 2003. Effects of habitat fragmentation on biodiversity. Annual Review of Ecology, Evolution, and Systematics 34 (1):487-515.

Fernández-Juricic, E., and J. Jokimäki. 2001. A habitat island approach to conserving birds in urban landscapes: case studies from southern and northern Europe. Biodiversity \& Conservation 10 (12):2023-2043.

Fischer, J., and D. B. Lindenmayer. 2007. Landscape modification and habitat fragmentation: a synthesis. Global Ecology and Biogeography 16 (3):265-280.

Forest Park Conservancy and Forest Park Alliance. 2013. Greater Forest Park Conservation Initiative. R. Myers, principal author. Last Accessed 18 November 2019 at www.forestparkconservancy.org

Goldspiel, H. B., J. B. Cohen, G. G. McGee, and J. P. Gibbs. 2019. Forest land-use history affects outcomes of habitat augmentation for amphibian conservation. Global Ecology and Conservation 19.

Gómez-Baggethun, E., Å. Gren, D. N. Barton, J. Langemeyer, T. McPhearson, P. O'Farrell, E. Andersson, Z. Hamstead, and P. Kremer. 2013. Urban Ecosystem Services. In Urbanization, Biodiversity and Ecosystem Services: Challenges and Opportunities: A Global Assessment, eds. T. Elmqvist, M. Fragkias, J. Goodness, B. Güneralp, P. J. Marcotullio, R. I. McDonald, S. Parnell, M. Schewenius, M. Sendstad, K. C. Seto, and C. Wilkinson, 175-251. Dordrecht: Springer Netherlands.

Gomez-Rodriguez, C., J. Bustamante, S. Koponen, and C. Diaz-Paniagua. 2008. Highresolution remote-sensing data in amphibian studies: identification of breeding sites and contribution to habitat models. Herpetological Journal 18 (2):103-113.

Grand, L., M. Hayes, K. Vogt, D. Vogt, P. Yarnold, K. Richter, C. Anderson, E. Ostergaard, and J. Wilhelm. 2017. Identification of habitat controls on northern redlegged frog populations: implications for habitat conservation on an urbanizing landscape in the Pacific Northwest. Ecological Processes 6 (1):1-13. 
Guderyahn, L. B., A. P. Smithers, and M. C. Mims. 2016. Assessing habitat requirements of pond-breeding amphibians in a highly urbanized landscape: implications for management. Urban Ecosystems 19 (4):1801-1821.

Guderyahn, L. B. 2019. Amphibians in the City: Presence, Influential Factors, and Recommendations for Portland, OR. City of Portland, Bureau of Parks and Recreation.

Gustafson, E. J. 1998. Quantifying Landscape Spatial Pattern: What Is the State of the Art? Ecosystems; New York 1 (2):143-156.

Haddad, N. M., L. A. Brudvig, E. I. Damschen, D. M. Evans, B. L. Johnson, D. J. Levey, J. L. Orrock, J. Resasco, L. L. Sullivan, J. J. Tewksbury, S. A. Wagner, and A. J. Weldon. 2014. Potential Negative Ecological Effects of Corridors. Conservation Biology 28 (5):1178-1187.

Hamer, A. J., and M. J. Mcdonnell. 2008. Amphibian ecology and conservation in the urbanising world: A review. Biological Conservation 141 (10):2432-2449.

Hannah, L., L. Flint, A. D. Syphard, M. A. Moritz, L. B. Buckley, and I. M. Mccullough. 2014. Fine-grain modeling of species' response to climate change: holdouts, steppingstones, and microrefugia. Trends in Ecology \& Evolution 29 (7):390-397.

Harris, N. L., E. Goldman, C. Gabris, J. Nordling, S. Minnemeyer, S. Ansari, M. Lippmann, L. Bennett, M. Raad, M. Hansen, and P. Potapov. 2017. Using spatial statistics to identify emerging hot spots of forest loss. Environmental Research Letters 12 (2).

Hayes, M. P., C. J. Rombough, and C. B. Hayes. 2007. Natural History: Rana aurora (Northern Red-legged Frog), movement. Herpetological Review 38:192-193.

Hayes, M. P., T. Quinn, K. O. Richter, J. P. Schuett-Hames, and J. T. Serra Shean. 2008. Maintaining Lentic-breeding Amphibians in Urbanizing Landscapes: The Case Study of the Northern Red-legged Frog (Rana aurora). Herpetological Conservation 3.

Hobbs, R. J., E. Higgs, C. M. Hall, P. Bridgewater, F. S. Chapin, E. C. Ellis, J. J. Ewel, L. M. Hallett, J. Harris, K. B. Hulvey, S. T. Jackson, P. L. Kennedy, C. Kueffer, L. Lach, T. C. Lantz, A. E. Lugo, J. Mascaro, S. D. Murphy, C. R. Nelson, M. P. Perring, D. M. Richardson, T. R. Seastedt, R. J. Standish, B. M. Starzomski, K. N. Suding, P. M. Tognetti, L. Yakob, and L. Yung. 2014. Managing the whole landscape: historical, hybrid, and novel ecosystems. Frontiers in Ecology and the Environment 12 (10):557564.

Holzer, K. A. 2014. Amphibian use of constructed and remnant wetlands in an urban landscape. Urban Ecosystems 17 (4):955-968. 
Holzer, K. A., R. P. Bayers, T. T. Nguyen, and S. P. Lawler. 2017. Habitat value of cities and rice paddies for amphibians in rapidly urbanizing Vietnam. Journal of Urban Ecology 3 (1).

Hanski, I. 1998. Metapopulation dynamics. Nature 396 (6706):41-49.

Johnson, C. J., and M. P. Gillingham. 2004. Mapping Uncertainty: Sensitivity of Wildlife Habitat Ratings to Expert Opinion. Journal of Applied Ecology 41 (6):1032-1041.

Keeley, A. T. H., D. D. Ackerly, D. R. Cameron, N. E. Heller, P. R. Huber, C. A. Schloss, J. H. Thorne, and A. M. Merenlender. 2018. New concepts, models, and assessments of climate-wise connectivity. Environmental Research Letters 13 (7).

Koen, E. L., J. Bowman, C. Sadowski, and A. A. Walpole. 2014. Landscape connectivity for wildlife: development and validation of multispecies linkage maps ed. A. Tatem. Methods in Ecology and Evolution 5 (7):626-633.

Lacher, I., and M. L. Wilkerson. 2014. Wildlife Connectivity Approaches and Best Practices in U.S. State Wildlife Action Plans. Conservation Biology 28 (1):13-21.

Lapoint, S., N. Balkenhol, J. Hale, J. Sadler, and R. Ree. 2015. Ecological connectivity research in urban areas. Functional Ecology 29 (7):868-878.

Lindenmayer, D., R. J. Hobbs, R. Montague-Drake, J. Alexandra, A. Bennett, M. Burgman, P. Cale, A. Calhoun, V. Cramer, P. Cullen, D. Driscoll, L. Fahrig, J. Fischer, J. Franklin, Y. Haila, M. Hunter, P. Gibbons, S. Lake, G. Luck, C. MacGregor, S. McIntyre, R. M. Nally, A. Manning, J. Miller, H. Mooney, R. Noss, H. Possingham, D. Saunders, F. Schmiegelow, M. Scott, D. Simberloff, T. Sisk, G. Tabor, B. Walker, J. Wiens, J. Woinarski, and E. Zavaleta. 2008. A checklist for ecological management of landscapes for conservation. Ecology Letters 11 (1):78-91.

McMahon, L. A., J. L. Rachlow, L. A. Shipley, J. S. Forbey, T. R. Johnson, and P. J. Olsoy. 2017. Evaluation of micro-GPS receivers for tracking small-bodied mammals. PLOS ONE 12 (3).

McRae, B. H., B. G. Dickson, T. H. Keitt, and V. B. Shah. 2008. Using Circuit Theory to Model Connectivity in Ecology, Evolution, and Conservation. Ecology 89 (10):27122724.

McRae, B. H., S. A. Hall, P. Beier, and D. M. Theobald. 2012. Where to Restore Ecological Connectivity? Detecting Barriers and Quantifying Restoration Benefits. PLOS ONE 7 (12). 
McRae, B. H., K. Popper, A. Jones, S. Buttrick, K. Hall, B. Unnasch, and J. Platt. 2016. Conserving Nature's Stage: Mapping Omnidirectional connectivity for the resilient terrestrial landscapes in the Pacific Northwest. The Nature Conservancy. Last Accessed 20 November 2019 at https://www.conservationgateway.org/ConservationByGeography/NorthAmerica/United States/oregon/science/Documents/McRae_et_al_2016_PNW_CNS_Connectivity.pdf

Metro

2006. Metro State of the Watersheds Monitoring Report 2006. Last Accessed 20 November 2019 at https://www.oregonmetro.gov/sites/default/files/2014/05/06/05162008_state_wate rsheds_report_baseline_conditions_2006.pdf

2014. Metro 2014 Urban Growth Report- Investing in our communities 20152035. Last Accessed 18 November 2019 at https://www.oregonmetro.gov/sites/default/files/2014/09/19/14226\%20Urban\%20 Growth\%20Report\%20Final\%20PLA_0.pdf

2016. Parks and Nature System Plan. Last Accessed 18 November 2019 at https://www.oregonmetro.gov/sites/default/files/2018/03/23/Parks-and-NatureSystem-Plan.pdf

2019. Gabbert Butte Nature Park Master Plan.

Last Accessed 18 November 2019 at https://www.oregonmetro.gov/sites/default/files/2019/07/18/GabbertButteNatureP arkMP_1.pdf

Mitchell, M., E. Bennett, and A. Gonzalez. 2013. Linking Landscape Connectivity and Ecosystem Service Provision: Current Knowledge and Research Gaps. Ecosystems 16:894-908.

Mondal, I., R. S. Kumar, B. Habib, and G. Talukdar. 2016. Modeling fine scale movement corridors for the Tricarinate Hill Turtle. ISPRS - International Archives of the Photogrammetry, Remote Sensing and Spatial Information Sciences XLI-B8:719-725.

Murphy, Y. M. 2009. Stream channel stability and sensitivity to landscape history and land use changes in Kelley Creek, Portland, Oregon. Last accessed 18 November 2019 at https://ir.library.oregonstate.edu/concern/graduate_thesis_or_dissertations/tb09j769w

Naidoo, R., J. W. Kilian, P. Du Preez, P. Beytell, O. Aschenborn, R. D. Taylor, and G. Stuart-Hill. 2018. Evaluating the effectiveness of local- and regional-scale wildlife corridors using quantitative metrics of functional connectivity. Biological Conservation 217:96-103. 
Nor, A. N. M., R. Corstanje, J. A. Harris, D. R. Grafius, and G. M. Siriwardena. 2017. Ecological connectivity networks in rapidly expanding cities. Heliyon 3 (6).

Nordén, E. 2016. Comparison between three landscape analysis tools to aid conservation efforts. Last Accessed 18 November 2019 at http://lup.lub.lu.se/luur/download?func=downloadFile\&recordOId=8893499\&fileOId=88 93500

Ostergaard, E., K. O. Richter, and S. West. 2008. Amphibian use of stormwater ponds in the Puget Lowlands of Washington, USA. Urban Hereptology. Society for the Study of Amphibians and Reptiles, Salt Lake City :259-270.

Oregon Department of Agriculture Tualatin Agricultural Water Quality Management Area Plan 2018. 2018. Last Accessed 20 November 2019 at https://www.oregon.gov/ODA/shared/Documents/Publications/NaturalResources/Tualati nAWQMAreaPlan.pdf

Pelletier, D., M. Clark, M. G. Anderson, B. Rayfield, M. A. Wulder, and J. A. Cardille. 2014. Applying Circuit Theory for Corridor Expansion and Management at Regional Scales: Tiling, Pinch Points, and Omnidirectional Connectivity ed. B. Hérault. PLoS ONE $9(1)$.

Poor, E. E., C. Loucks, A. Jakes, and D. L. Urban. 2012. Comparing Habitat Suitability and Connectivity Modeling Methods for Conserving Pronghorn Migrations ed. M. FestaBianchet. PLoS ONE 7 (11).

Porej, D., M. Micacchion, and T. E. Hetherington. 2004. Core terrestrial habitat for conservation of local populations of salamanders and wood frogs in agricultural landscapes. Biological Conservation 120 (3):399-409.

Proctor, M., S. Nielsen, W. Kasworm, C. Servheen, T. Radandt, A. Machutchon, and M. Boyce. 2015. Grizzly bear connectivity mapping in the Canada-United States transborder region: Grizzly Bear Connectivity Mapping. The Journal of Wildlife Management 79.

PSU-Metro. n.d. Working Title- Metro Regional Habitat Connectivity Toolkit. In Progress for Publication.

Rabinowe, J. H., J. T. Serra, M. P. Hayes, and T. Quinn. 2002. Natural history notes: Rana aurora aurora (northern red-legged frog). Herpetological Review 33:128.

Rogers, N. M. 2017. Urban Connections: A comparison of connectivity assessment methods. Last Accessed 18 November 2019 at https://pdxscholar.library.pdx.edu/cgi/viewcontent.cgi?article=1038\&context=mem_grad projects 
Romero-Calcerrada, R., and S. Luque. 2006. Habitat quality assessment using Weightsof-Evidence based GIS modelling: The case of Picoides tridactylus as species indicator of the biodiversity value of the Finnish forest. Ecological Modelling 196 (1):62-76.

Rose, A. J. 2013. Systematic comparison of two habitat connectivity modeling approaches: Least cost path and circuit theory. Last Accessed 18 November 2019 at https://tigerprints.clemson.edu/all_theses/1634/

Rowe, J. C., A. Duarte, C. A. Pearl, B. McCreary, S. K. Galvan, J. T. Peterson, and M. J. Adams. 2019. Disentangling effects of invasive species and habitat while accounting for observer error in a long-term amphibian study. Ecosphere 10 (4).

Rudnick, D. A., S. J. Ryan, P. Beier, S. A. Cushman, F. Dieffenbach, C. W. Epps, L. R. Gerber, J. Hartter, J. S. Jenness, J. Kintsch, A. M. Merenlender, R. M. Perkl, D. V.

Preziosi, and S. C. Trombulak. 2012. The role of landscape connectivity in planning and implementing conservation and restoration priorities. Issues in Ecology. 16(Fall): 1-20. $: 1-20$.

Saura, S., Ö. Bodin, and M.-J. Fortin. 2014. EDITOR'S CHOICE: Stepping stones are crucial for species' long-distance dispersal and range expansion through habitat networks. Journal of Applied Ecology 51 (1):171-182.

Schroeder, M. A., A. J. Shirk, A. Wells, and L. A. Robb. 2015. Habitat Occupancy and Movements by Greater Sage-Grouse in Washington State Final-Report 2015.

Last Accessed 14 May 2019 at https://waconnected.org/wp-

content/uploads/2015/12/GNLCCF14AP01042_Final-Report_2015.pdf

Schuett-Hames, J. 2004. Northern Red-Legged Frog (Rana aurora aurora) Terrestrial Habitat Use in the Puget Lowlands of Washington. Last Accessed 31 August 2019 at http://archives.evergreen.edu/masterstheses/Accession86-10MES/Schuett-HJMESthesis2004.pdf

Schwartz, M. W. 1999. Choosing the appropriate scale of reserves for conservation. Annual Review of Ecology and Systematics 30:83.

Sha, Z., Y. Ali, Y. Wang, J. Chen, X. Tan, and R. Li. 2018. Mapping the Changes in Urban Greenness Based on Localized Spatial Association Analysis under Temporal Context Using MODIS Data. ISPRS Int. J. Geo-Information 7:407.

Singleton, P., and B. McRae. 2013. Assessing habitat connectivity. Conservation planning: Shaping the future ed F.L. Craighead and C.L. Convis ESRI Press, Redlands CA. 
Soule, M. E. 1991. Land-use planning and wildlife maintenance- guidelines for conserving wildlife in an urban landscape. Journal Of The American Planning Association 57 (3):313-323.

Spear, S. F., N. Balkenhol, M.-J. Fortin, B. H. Mcrae, and K. Scribner. 2010. Use of resistance surfaces for landscape genetic studies: considerations for parameterization and analysis. Molecular Ecology 19 (17):3576-3591.

Spencer, W. D., P. Beier, K. Penrod, K. Winters, C. Paulman, H. Rustigian-Romsos, J. Strittholt, M. Parisi, and A. Pettler. 2010. California Essential Habitat Connectivity Project: a strategy for Conserving a Connected California. Last Accessed 18 September 2019 at https://www.wildcalifornia.org/wpcontent/uploads/2014/04/CEHC_Plan_MASTER_030210_3-reduced.pdf

Standish, R., R. Hobbs, and J. Miller. 2013. Improving city life: options for ecological restoration in urban landscapes and how these might influence interactions between people and nature. Landscape Ecology 28 (6):1213-1221.

Sutherland, R. W., P. B. Leonard, R. Carnes, D. Fedak, and R. Baldwin. 2014. Terrestrial habitat connectivity models for the South Atlantic Landscape Conservation Cooperative. Wildlands Network.

The Pinal County Wildlife Connectivity Assessment: Report on Stakeholder Input. 2013. Last accessed 13 September 2019 at https://nhnm.unm.edu/sites/default/files/nonsensitive/newsfiles/PinalCountyStakeholderLinkagesReport.pdf

U.S. Environmental Protection Agency Clean Water Act Section 404. Last Accessed 20 November 2019 at https://www.epa.gov/cwa-404/background-about-compensatorymitigation-requirements-under-cwa-section-404

U.S. Fish and Wildlife. 2017. Willamette Valley Conservation Study Strategic. Pacific Region, Portland, Oregon.

Vos, C. C., and J. P. Chardon. 1998. Effects of Habitat Fragmentation and Road Density on the Distribution Pattern of the Moor Frog Rana arvalis. Journal of Applied Ecology 35 (1):44-56.

Wade, A. A., K. S. McKelvey, and M. K. Schwartz. 2015. Resistance-surface-based wildlife conservation connectivity modeling: Summary of efforts in the United States and guide for practitioners. Ft. Collins, CO: U.S. Department of Agriculture, Forest Service, Rocky Mountain Research Station. Last Accessed 19 September 2019 at https://www.fs.usda.gov/treesearch/pubs/48464 
Walpole, A. A., J. Bowman, D. L. Murray, and P. J. Wilson. 2012. Functional connectivity of lynx at their southern range periphery in Ontario, Canada. Landscape Ecology 27 (5):761-773.

Walsh, C. J., A. H. Roy, J. W. Feminella, P. D. Cottingham, P. M. Groffman, and R. P. Morgan. 2005. The urban stream syndrome: current knowledge and the search for a cure. Journal of the North American Benthological Society 24 (3):706-723.

Watts, A. G., P. Schlichting, S. Billerman, B. Jesmer, S. Micheletti, M.-J. Fortin, C. Funk, P. Hapeman, E. L. Muths, and M. A. Murphy. 2015. How spatio-temporal habitat connectivity affects amphibian genetic structure. Frontiers in Genetics 6:275.

Wu, Q., C. Lane, and H. Liu. 2014. An Effective Method for Detecting Potential Woodland Vernal Pools Using High-Resolution LiDAR Data and Aerial Imagery. Remote Sensing 6 (11):11444-11467.

Zeller, K. A., M. K. Jennings, T. W. Vickers, H. B. Ernest, S. A. Cushman, and W. M. Boyce. 2018. Are all data types and connectivity models created equal? Validating common connectivity approaches with dispersal data. Diversity and Distributions 24 (7):868-879.

Data Sources

Metro RLIS 2019. Download at http://rlisdiscovery.oregonmetro.gov/

Oregon Department of Land Conservation and Development. 2016. https://www.oregon.gov/lcd/About/Pages/Maps-Data-Tools.aspx

PSU-Metro 2018. Species Models. In progress. Currently no download available.

PSU-INR 2018. Oregon State Wide Habitat Map. Part of Oregon GIS Framework. Oregon Biodiversity Information Center at Portland State University and Oregon Department of Fish and Wildlife (ODFW), Institute of Natural Resources.

Download at https://spatialdata.oregonexplorer.info/osdlgeoportal/catalog/search/resource/details.page?uuid=\%7B4F271C43-605A-48F3-B1EDF89F35F0DB29\%7D

RCS-INR 2012. Regional Conservation Strategy, Intertwine Alliance, Institute of Natural Resources. Download at http://www.regionalconservationstrategy.org/page/datadownloa 


\section{GIS Tools}

ESRI 2018. ArcGIS Desktop: Release ArcMap 10.6x. Redlands, CA: Environmental Systems Research Institute.

McRae, B.H., V.B. Shah, and T.K. Mohapatra. 2013. Circuitscape 4 User Guide. The Nature Conservancy. http://www.circuitscape.org.

Maps made in

ESRI 2019. ArcGIS Desktop: Release ArcGIS Pro 2.x. Redlands, CA: Environmental Systems Research Institute. 


\section{Appendix A: \\ Glossary}

\section{A.1 General Metro Toolkit Terminology} (Adapted from PSU-Metro 2018)

\section{Barrier}

Braided Pathways

\section{Combined Scores}

(Overall Scores)

Field Scores

GIS Scores

Habitat
Feature that disrupts connectivity or inhibits movement between habitat patches. These can include natural topographic features such as fastmoving streams, mountain ranges, or cliff sides. They can also include human-made features and human disturbances such as retaining walls, roads, fences, noise, light, or development. Mitigation strategies are used to remove features or increase the permeability of barriers with additions like road crossings and culvert passages. GIS Barrier value $=1$.

Connectivity type for Circuitscape model to prioritize connectivity management. Multiple linkages, constrained, intertwined, reticulated. Typically appear as many pathways in multiple directions, or many different connectivity values in close proximity. Braided paths can be narrow or dispersed. These may offer multiple options in a place with numerous barriers or patchy habitat but can also redirect wildlife to nonideal habitats.

Scores are generated with habitat assessment sheets and species scorecards from the Metro Regional Habitat Connectivity Toolkit. Thirty-four (34) GIS derived and field collected scores are combined into a single score percentage out of the total raw score for the species scorecard. Northern Red-legged Frog raw scores were out of 389 at the time of this project and will continue to be updated.

Field-collected scores, generated with habitat assessment sheets and species scorecards from the Metro Regional Habitat Connectivity Toolkit. Surveyors evaluate habitat connectivity zones or sites and fill in nineteen (19) habitat characteristics. Surveyors may also verify GIS scores using field or aerial photography methods.

GIS-derived scores, generated with habitat assessment sheets and species scorecards from the Metro Regional Habitat Connectivity Toolkit. GIS data and GIS tools are used to evaluate fifteen (15) habitat characteristics. GIS data can be verified by surveyors in the field or using aerial photography.

Potential connectivity patch containing preferred matrix characteristics, water sources, vegetation, structural components (snags, rock piles, etc.), wildlife observations (signs, tracks, occupancy), human disturbance at manageable low levels (managed trail use, public parks, natural areas). Habitat is considered modeled for suitability, scored using habitat assessment sheets and ranking scheme, or by validated data from 


\section{Habitat Connectivity \\ Habitat Connectivity Zone (HCZ)}

\section{Permeable}

\section{Pinch Point}

\section{Scorecard}

tracking wildlife. The habitat functions as a necessary part of the wildlife's movement behaviors, life stages, refugia, or genetic dispersal to maintain survival. GIS Habitat value $=3$

Habitat connectivity is of particular importance to wildlife because it functions at a local scale to support individuals, metapopulations, or communities by linking permeable habitat patches that facilitate dispersal movement and wildlife survival. It targets the ability of organisms and/or their genetic material to move among their populations and potential habitats.

Preliminary HCZ were digitized based on a $250 \mathrm{~m}$ buffered centerline where the highest connectivity areas species were located. Each HCZ is approximately $500 \times 500$ meters and custom adjusted by size and shape to best contour landscape features and property lines visible on aerial maps. Each zone edge was placed on a road barrier, waterway, or other feature like fencing if they completely bisected the zone. Connective overlap between adjacent $\mathrm{HCZ}$ was at minimum $50 \mathrm{~m}$ and typically between 250-500 $\mathrm{m}$ wide. This method for delineating HCZ would ensure surveyor line of sight was possible to completely fill out assessment sheets and conduct repeat surveys if needed.

Features that are not considered habitat but facilitate connections or allow movement between habitat patches. High permeability features are suitable for movement, and low permeability features constrain movement. Permeability can be weighted based on the level of disturbance to the wildlife species. For example, rural trails, low traffic volume roads, and low intensity development activity may be permeable for some species depending on their movement behaviors but would be barriers to sensitive species. GIS Permeable value $=2$

Connectivity type for Circuits cape model to prioritize connectivity management. Narrow pathways which appear as constricted or pinched. Typically, these features have high connectivity values but are geographically narrow. The upper threshold, top $25 \%$ values, appear as concentrated areas on the map. These are not always ideal pathways for terrestrial wildlife and may restrict movement if along a confined riparian corridor or roadside median with minimum terrestrial habitat.

Species-specific scoring scheme accompanied by habitat characteristics and associated GIS values $0=$ no effect, $1=$ barrier, $2=$ =permeable, $3=$ habitat, $\mathrm{n} / \mathrm{s}=$ not scored. Weighted multipliers ranging from 0-9 highlights extra importance for wildlife movement, functional habitat, or other needs such as migration or breeding dependencies on habitat characteristics. 
Sheet Flows

Connectivity type for Circuitscape model to prioritize connectivity management. Diffuse, parallel connections, wide or broad with similar connectivity values. Typically appears as a wide swatch of homogenous connectivity. These linkages are the bottom $75 \%$ values and rarely appear as wide linkages of upper $25 \%$ values. Sometimes appear as gradients with higher center values to lower values on edges. These are ideal pathways for terrestrial wildlife with wide dispersal ranges or with sensitivity to edge effect along habitat corridors. 


\begin{tabular}{|c|c|}
\hline \multicolumn{2}{|r|}{$\begin{array}{c}\text { A.2 GIS Data Glossary } \\
\text { (Adapted from PSU-Metro 2018) }\end{array}$} \\
\hline $\begin{array}{l}\text { Connectivity and } \\
\text { Patch Matrix }\end{array}$ & $\begin{array}{c}\text { Methods } \\
\text { (RCS-INR Data) }\end{array}$ \\
\hline $\begin{array}{l}\text { Dominant } \\
\text { matrix type } \\
\text { Agriculture__\% } \\
\text { Developed_\% }\end{array}$ & $\begin{array}{l}\text { Tabulate Area tool } \\
\text { Use Level } 0 \text { Class Name (INR_Veg) } \\
\text { Agriculture, Developed }\end{array}$ \\
\hline $\begin{array}{l}\text { Hardscaping } \\
\text { Hardscaping _ } \%\end{array}$ & $\begin{array}{l}\text { Tabulate Area tool } \\
\text { Use Level } 2 \text { Class Name (INR_Veg) } \\
\text { Paved,built small } \\
\text { impervious surfaces includes roads, parking lots etc. } \\
\text { does not include structures }\end{array}$ \\
\hline $\begin{array}{l}\text { Minimum width of } \\
\text { natural areas within } \\
\text { connectivity zone } \\
\text { _ meters }\end{array}$ & $\begin{array}{l}\text { Measure tool } \\
\text { Use Level } 0 \text { Class Name (INR_Veg) } \\
\text { All developed and agriculture pixels (the matrices) homogeneous color to } \\
\text { differentiate from natural areas. } \\
\text { Use measure tool on minimum width and utilize aerial imagery if } \\
\text { necessary. Measure along largest connectivity path that connects one HCZ } \\
\text { to another. A gap in the path, or no connective path should be a minimum } \\
\text { width equal to } 0 \text {. If the entire HCZ is natural area, the minimum width is } \\
\text { equal to approximately } 500 \mathrm{~m} \text { (standardized width of zones). }\end{array}$ \\
\hline $\begin{array}{l}\text { Structures } \\
\text { Structures _ } \%\end{array}$ & $\begin{array}{l}\text { Tabulate Area tool } \\
\text { Use Level } 2 \text { Class Name (INR_Veg) } \\
\text { Building types (Building detected/built medium, and building burned } \\
\text { in/built tall) } \\
\text { Structures do not include paved,built small }\end{array}$ \\
\hline Water Sources & Methods \\
\hline $\begin{array}{l}\text { Water source within } \\
\text { connectivity zone? } \\
\text { Yes / No } \\
\text { Type: stream pond }\end{array}$ & $\begin{array}{l}\text { Use aerial imagery } \sim 5 \mathrm{~m} \text { to confirm presence and type } \\
\text { Or use egg mass survey sites, ponds, stormwater ponds, stream channel, } \\
\text { wetlands layers if available }\end{array}$ \\
\hline
\end{tabular}




\begin{tabular}{|c|c|}
\hline $\begin{array}{l}\text { Open Water } \\
\text { Open water } \\
\text { Fragmented/ } \\
\text { Contiguous }\end{array}$ & $\begin{array}{l}\text { Level 0, Class Name Open water (INR_Veg) } \\
\text { Use aerial imagery to validate if necessary }\end{array}$ \\
\hline $\begin{array}{l}\text { Distance of corridor } \\
\text { edge from water } \\
\text { If answer to water source } \\
\text { is no then report distance } \\
\text { to water here: } \\
\quad \text { Meters }\end{array}$ & $\begin{array}{l}\text { Measure } \\
\text { Use aerial imagery, with Level 0, Class Name (INR_Veg) open water } \\
\text { Use measure tool from zone edge to closest water source (stream, pond, } \\
\text { wetland, reservoir, etc...) and label if known name. }\end{array}$ \\
\hline Vegetation & Methods \\
\hline $\begin{array}{l}\text { Conifer Forest } \\
\text { Conifer Forest__ } \% \\
\text { Fragmented / } \\
\text { Contiguous }\end{array}$ & $\begin{array}{l}\text { Tabulate Area } \\
\text { Use Level } 2 \text { Class Name } \\
\text { All conifer (varying heights) }\end{array}$ \\
\hline $\begin{array}{l}\text { Deciduous Forest } \\
\text { Deciduous Forest _\% } \\
\text { Fragmented / } \\
\text { Contiguous }\end{array}$ & $\begin{array}{l}\text { Tabulate Area } \\
\text { Use Level } 2 \text { Class Name } \\
\text { All hardwood (varying heights) }\end{array}$ \\
\hline $\begin{array}{l}\text { Maximum canopy } \\
\text { gap (trees) } \\
\end{array}$ & $\begin{array}{l}\text { Use aerial imagery with Level 2, Class name (INR_Veg) Conifer (varying } \\
\text { heights), Hardwood (varying heights), Mixed Forest } \\
\text { Use measure tool for maximum canopy gap (no trees present) from canopy } \\
\text { edge to canopy edge. Aerial imagery can also be used. }\end{array}$ \\
\hline $\begin{array}{l}\text { Riparian } \\
\text { area/Woody species } \\
\text { along stream } \\
\text { (if present) } \\
\text { Yes / No } \\
\quad \% \text { cover }\end{array}$ & $\begin{array}{l}\text { Approximate percentage out of whole Zone. } \\
\text { Vegetation or canopy along stream edge }\end{array}$ \\
\hline
\end{tabular}




\begin{tabular}{|l|l|}
\hline $\begin{array}{l}\text { Wetland } \\
\text { Wetland } \\
\text { Fragmented }\end{array}$ & $\begin{array}{l}\text { Tabulate Area } \\
\text { Use wetland layer }\end{array}$ \\
\hline $\begin{array}{l}\text { Maximum ground } \\
\text { cover gap (no veg) } \\
\text { Meters }\end{array}$ & $\begin{array}{l}\text { Use aerial imagery with land cover. Examples of ground cover gaps include } \\
\text { Open water, developed areas (including fallow agricultural fields), and bare } \\
\text { ground. }\end{array}$ \\
$\begin{array}{l}\text { Gap of type: } \\
\text { Open water } \\
\text { Developed } \\
\text { Bare ground }\end{array}$ & $\begin{array}{l}\text { Use measure tool for maximum ground cover gap from vegetative edge to } \\
\text { vegetative edge across. }\end{array}$ \\
\end{tabular}




\begin{tabular}{|c|c|}
\hline \multicolumn{2}{|c|}{$\begin{array}{l}\text { A.3 Field Collection Methods } \\
\text { (Adapted from PSU-Metro 2018) }\end{array}$} \\
\hline Habitat Characteristics & Method \\
\hline \multicolumn{2}{|l|}{ Connectivity and Patch Matrix } \\
\hline $\begin{array}{l}\text { Dominant Matrix Type } \\
\text { (agricultural and/or developed and } \\
\text { report \% cover of each) }\end{array}$ & $\begin{array}{l}\text { Use the corresponding values in the GIS data collection } \\
\text { table. Verify with field observation and aerial photo, } \\
\text { correcting values as needed. }\end{array}$ \\
\hline $\begin{array}{l}\text { Ag type: (low crop, orchard, corn) } \\
\text { Dom type: (residential, commercial, } \\
\text { industrial) }\end{array}$ & $\begin{array}{l}\text { Describe the specific type of matrix characteristics } \\
\text { observed. }\end{array}$ \\
\hline $\begin{array}{l}\text { Minimum width of natural (non- } \\
\text { matrix) land cover } \\
\text { (report distance in meters) }\end{array}$ & $\begin{array}{l}\text { Use the corresponding values in the GIS data collection } \\
\text { table. Consider the HCZ and theoretical direction of } \\
\text { travel of wildlife moving through the zone. If the } \\
\text { natural (non-matrix) land cover is not connected across } \\
\text { the zone then the minimum width will be } 0 \text {. If it is } \\
\text { connected, look for the most constricted area and } \\
\text { measure/verify the width. }\end{array}$ \\
\hline $\begin{array}{l}\% \text { Hardscaping } \\
\text { (report \% cover of pavement or } \\
\text { other impermeable land cover } \\
\text { excluding structures) }\end{array}$ & $\begin{array}{l}\text { Use the corresponding values in the GIS data collection } \\
\text { table. Verify with field observation and aerial photo, } \\
\text { correcting values as needed. At times, GIS will classify } \\
\text { open water as developed, resulting in an overestimation } \\
\text { of this parameter. }\end{array}$ \\
\hline $\begin{array}{l}\% \text { Structures } \\
\text { (report \% cover of buildings or other } \\
\text { above ground infrastructure) }\end{array}$ & $\begin{array}{l}\text { Use the corresponding values in the GIS data collection } \\
\text { table. Verify with field observation and aerial photo, } \\
\text { correcting values as needed. }\end{array}$ \\
\hline \multicolumn{2}{|l|}{ Water Source } \\
\hline $\begin{array}{l}\text { Water source within connectivity } \\
\text { zone (y/n and indicate type: stream, } \\
\text { pond) }\end{array}$ & $\begin{array}{l}\text { Use the corresponding values in the GIS data collection } \\
\text { table. Verify with field observation and aerial photo, } \\
\text { correcting values as needed. }\end{array}$ \\
\hline $\begin{array}{l}\text { Open water } \% \text { cover and distribution } \\
\text { (report } \% \text { and if open water is } \\
\text { fragmented or contiguously } \\
\text { distributed across the HCZ) }\end{array}$ & $\begin{array}{l}\text { Use the corresponding values in the GIS data collection } \\
\text { table. Verify with field observation and aerial photo, } \\
\text { correcting values as needed. Streams typically do not } \\
\text { provide a \% cover value in GIS so an estimation will } \\
\text { need to be provided based on field observation. } \\
\text { Additionally, at times GIS has been found to incorrectly }\end{array}$ \\
\hline
\end{tabular}




\begin{tabular}{|c|c|}
\hline & $\begin{array}{l}\text { classify open water as developed, resulting in an under } \\
\text { representation of actual \% cover in these cases. }\end{array}$ \\
\hline $\begin{array}{l}\text { Distance of HCZ edge from water } \\
\text { (report distance in meters) }\end{array}$ & $\begin{array}{l}\text { If there is no water source within the HCZ, then } \\
\text { document here how far the nearest source of water is } \\
\text { from the edge of the HCZ. Use the corresponding } \\
\text { values in the GIS data collection table. Verify with field } \\
\text { observation and aerial photo, correcting values as } \\
\text { needed. If there is water present in the HCZ then report } \\
\text { the distance as } 0 \text {. }\end{array}$ \\
\hline $\begin{array}{l}\text { Seasonality } \\
\text { (ephemeral, intermittent, perennial) }\end{array}$ & $\begin{array}{l}\text { This category describes the seasonality of the waterbody } \\
\text { (if present). We suggest conducting surveys during the } \\
\text { summer hydroperiod in order to capture low water } \\
\text { levels most accurately. If seasonality of the stream is } \\
\text { unknown, estimate based on data available for the } \\
\text { stream line through GIS or supplemental field surveys. }\end{array}$ \\
\hline $\begin{array}{l}\text { Substrate } \\
\text { (sediment, cobble, aquatic } \\
\text { vegetation, rip rap, concrete) }\end{array}$ & Describe the dominant substrates of the waterbody \\
\hline $\begin{array}{l}\text { Channel Stability } \\
\text { (straight or meandering) }\end{array}$ & $\begin{array}{l}\text { If the waterbody within the } \mathrm{HCZ} \text { is a stream, then } \\
\text { describe the channel stability }\end{array}$ \\
\hline $\begin{array}{l}\text { Bank Condition } \\
\text { (Incised or sloped) }\end{array}$ & $\begin{array}{l}\text { If the waterbody within the } \mathrm{HCZ} \text { is a stream, then } \\
\text { describe the bank condition }\end{array}$ \\
\hline \multicolumn{2}{|l|}{ Vegetation } \\
\hline $\begin{array}{l}\text { Conifer Forest \% cover and } \\
\text { distribution } \\
\text { (report \% and if conifer forest is } \\
\text { fragmented or contiguously } \\
\text { distributed across the HCZ) }\end{array}$ & $\begin{array}{l}\text { Use the corresponding values in the GIS data collection } \\
\text { table. At times GIS has inaccurately estimated the \% } \\
\text { cover, likely due to the nature of the size of a mature } \\
\text { conifer tree in proportion to the pixel size of the data. } \\
\text { Verify with field observation and aerial photo, } \\
\text { correcting values as needed. }\end{array}$ \\
\hline $\begin{array}{l}\text { Deciduous Forest \% cover and } \\
\text { distribution } \\
\text { (report \% and if deciduous forest is } \\
\text { fragmented or contiguously } \\
\text { distributed across the HCZ) }\end{array}$ & $\begin{array}{l}\text { Use the corresponding values in the GIS data collection } \\
\text { table. At times GIS has inaccurately estimated the \% } \\
\text { cover, likely due to the nature of the size of an } \\
\text { individual deciduous trees canopy in proportion to the }\end{array}$ \\
\hline
\end{tabular}




\begin{tabular}{|c|c|}
\hline & $\begin{array}{l}\text { pixel size of the data. Verify with field observation and } \\
\text { aerial photo, correcting values as needed. }\end{array}$ \\
\hline $\begin{array}{l}\text { Oak Woodland \% cover and } \\
\text { distribution } \\
\text { (report \% and if oak woodland is } \\
\text { fragmented or contiguously } \\
\text { distributed across the HCZ) }\end{array}$ & $\begin{array}{l}\text { Use the corresponding values in the GIS data collection } \\
\text { table. Verify with field observation and aerial photo, } \\
\text { correcting values as needed. } \\
\text { *Note that the oak layer is currently under development and may not } \\
\text { be available immediately at the time of publication of this user } \\
\text { guide. }\end{array}$ \\
\hline $\begin{array}{l}\text { Maximum canopy gap (trees) } \\
\text { (report distance in meters) }\end{array}$ & $\begin{array}{l}\text { Use the corresponding values in the GIS data collection } \\
\text { table. Consider the HCZ and theoretical direction of } \\
\text { travel of wildlife moving through the zone. If the } \\
\text { canopy is contiguous across the zone then the maximum } \\
\text { gap will be } 0 . \text { If it is fragmented, look for the largest } \\
\text { gap and measure/verify the width. }\end{array}$ \\
\hline $\begin{array}{l}\text { Riparian area/Woody species along } \\
\text { stream (if stream is present) } \\
\text { (Report \% cover) }\end{array}$ & $\begin{array}{l}\text { Use the corresponding values in the GIS data collection } \\
\text { table. Verify with field observation and aerial photo, } \\
\text { correcting values as needed. }\end{array}$ \\
\hline $\begin{array}{l}\text { Of the trees present estimate the } \\
\text { proportion of specific tree species } \\
\text { and estimate tree age composing the } \\
\text { canopy. } \\
\text { (for each species indicate what } \\
\text { proportion of the forested area they } \\
\text { occupy using the following range } \\
\text { values: } 0-5 \%, 5-25 \%, 25-50 \%, 50 \text { - } \\
75 \%, 75-100 \% \text { ) }\end{array}$ & $\begin{array}{l}\text { Considering the entire forested area within the } \mathrm{HCZ} \text { as } \\
100 \% \text {, estimate what proportion is occupied by each } \\
\text { species. Please note this proportion describes the total } \\
\text { canopy within the HCZ and not necessarily the total } \\
\text { HCZ land cover. } \\
\text { For each species, note what proportion is represented by } \\
\text { each age class. For example, of all the Doug firs } \\
\text { present, } 25 \% \text { were sapling, } 25 \% \text { were young and } 50 \% \\
\text { were mature. }\end{array}$ \\
\hline $\begin{array}{l}\text { (for each species also indicate the } \\
\text { proportion of each age class present: } \\
\text { mature, young and/or sapling, using } \\
\text { the following range values: } 0-5 \%, 5- \\
25 \%, 25-50 \%, 50-75 \%, 75-100 \% \text { ) }\end{array}$ & $\begin{array}{l}\text { Common native species are pre-written on the } \\
\text { assessment form, but the list should not be considered } \\
\text { exhaustive. Additional species should be added to } \\
\text { "Write in" categories as needed. Additionally, non- } \\
\text { native species commonly used in landscaping can be } \\
\text { lumped in the "ornamental spp." category. }\end{array}$ \\
\hline
\end{tabular}



Overall structural diversity of
vegetation
(no vegetation, one layer, two layers
present, most canopy layers present,
well defined multi-storied canopy)

Shrub \% cover and distribution (report \% and if shrubs are fragmented or contiguously distributed across the HCZ)

Native shrub layer percent cover (estimate \% cover with the following range values: $0-5 \%, 5-$ $25 \%, 25-50 \%, 50-75 \%, 75-100 \%$, report species observed)

Percent non-native vegetation (report \% cover using the following range values: $0-5 \%, 5-25 \%, 25-$ $50 \%, 50-75 \%, 75-100 \%$ )

Wetland $\%$ cover and distribution (report \% and if the wetland is fragmented or contiguously distributed across the HCZ)

Top 1-2 dominant herbaceous species

(report species (if visible) and describe the conditions using the following categories - terrestrial: understory (shaded), open (full sun), combination (part sun) and/or aquatic: emergent, submerged)
Structural diversity describes the vertical heterogeneity of the vegetation including the herbaceous, shrub, lower story tree, and upper story tree layers. This description should be applied to the natural (non-matrix) areas within the HCZ.

Estimate the proportion of shrub cover based on field and aerial survey. Shrub cover can often be estimated based on forest cover, depending on the structural complexity observed within the forested areas.

**Note: the following native, and non-native shrub layer characteristics (below) comprise the overall shrub \% cover

Considering the shrub \% cover within the $\mathrm{HCZ}$ as $100 \%$, estimate what proportion is occupied by native species (including willow). Include a list of species observed, making particular note of species that are also nectaring (flowering). Some species are provided as reference on the assessment sheet, but the list should not be considered exhaustive. Write in as needed.

Considering the overall vegetation cover of the HCZ, document the \% cover of invasive vegetation. This excludes non-native trees which can be recorded under tree species percentages above. Include a list of species observed. Some species are provided as reference on the assessment sheet, but the list should not be considered exhaustive. Write in as needed.

Use the corresponding values in the GIS data collection table. Verify with field observation and aerial photo, correcting values as needed.

If visible note the first and second most dominant herbaceous species ID.

Identify the appropriate conditions contributing to the herbaceous vegetative layer as provided on the assessment sheet. 


\begin{tabular}{|c|c|}
\hline $\begin{array}{l}\text { Maximum ground cover gap (no } \\
\text { vegetation) } \\
\text { (report in meters) }\end{array}$ & $\begin{array}{l}\text { Use the corresponding values in the GIS data collection } \\
\text { table. Consider the HCZ and theoretical direction of } \\
\text { travel of wildlife moving through the zone. If there is no } \\
\text { gap in vegetative cover then the maximum ground cover } \\
\text { gap will be } 0 \text {. If there is a gap, look for the largest area } \\
\text { and measure/verify the width. }\end{array}$ \\
\hline \multicolumn{2}{|l|}{ Other Structural Components } \\
\hline $\begin{array}{l}\text { Downed wood } \\
\text { (Note the type: logs, branches, } \\
\text { rootwad/stumps, and density of } \\
\text { each: high, medium, low, not } \\
\text { visible) }\end{array}$ & $\begin{array}{l}\text { Document the presence and density of downed wood } \\
\text { types. If described as "not visible" this indicates that the } \\
\text { downed wood type may be present in the HCZ, but were } \\
\text { not directly observed. }\end{array}$ \\
\hline $\begin{array}{l}\text { Snags } \\
\text { (Yes/No/Not visible, If visible then } \\
\text { describe abundance, height, dbh, } \\
\text { species and grade of decay where } \\
\text { possible). }\end{array}$ & $\begin{array}{l}\text { Document presence of snags if visible and additional } \\
\text { information as noted. If described as "not visible" this } \\
\text { indicates that snags may be present in the HCZ, but } \\
\text { were not directly observed. }\end{array}$ \\
\hline $\begin{array}{l}\text { Talus slopes/rock piles } \\
\text { (Yes/No/Not visible, If yes report if } \\
\text { present in a flooded area and/or } \\
\text { receiving sun exposure, what } \\
\text { proportion is sun exposed and what } \\
\text { is the aspect (south facing slope?) }\end{array}$ & $\begin{array}{l}\text { Document the presence of talus slopes and/or rock piles } \\
\text { and associated condition as noted. If described as "not } \\
\text { visible" this indicates that talus slopes may be present in } \\
\text { HCZ, but were not directly observed. }\end{array}$ \\
\hline $\begin{array}{l}\text { Duff layer/Thatch } \\
\text { (none, }<10 \mathrm{~cm} \text { partially } \\
\text { decomposed, } \\
>10 \mathrm{~cm} \text { partially decomposed) }\end{array}$ & $\begin{array}{l}\text { Consider the natural (non-matrix) areas of the } \mathrm{HCZ} \text { and } \\
\text { describe duff layer/thatch conditions in those areas. }\end{array}$ \\
\hline \multicolumn{2}{|l|}{ Wildlife Observations } \\
\hline $\begin{array}{l}\text { Wildlife sign and observations in the } \\
\text { field } \\
\text { (List the species and associate sign) }\end{array}$ & $\begin{array}{l}\text { Note any indication of wildlife presence and activity. } \\
\text { Include type of observation such as tracks, droppings, } \\
\text { burrows, etc. }\end{array}$ \\
\hline Human Disturbance & \\
\hline
\end{tabular}


Use by pets or domestic animals (describe and rate intensity: no evidence, some evidence, regular use apparent)

Trails/other evidence of regular human presence/activity (describe and rate intensity: no evidence, some evidence, regular use apparent)

Specific activities that may influence wildlife movements (describe and rate intensity of human activity: zero, light, moderate, heavy)
Circle the intensity of use and note any additional details observed. For example the presence of livestock, frequent use by dog walkers, outdoor cats observed, etc.

Circle the intensity of use and note any additional details observed. For example the presence of transient camps, trash or dumping sites.

Circle the intensity of use and note any additional details observed. For example specific activities may include attraction to refuse, avoidance of industrial activities, frequent noise. 


\section{A.4 Data Sources}

Data sources are listed in alphabetical order and come from either regional datasets, public data basin websites, local managers, or collected from radio-telemetry and Metro Regional Habitat Connectivity Toolkit assessments. All regional data sources such as aerial imagery, boundaries/reference layers, land cover, and zoning/land use development type were produced or updated between 2012-2019. Metro Regional Habitat Connectivity Toolkit Habitat quality scores were collected in early Summer 2018 in Gresham East Buttes, around the time ponds begin to dry up and R.aurora tadpoles hatch and develop. Aquatic habitat locations were not validated in 2018. The R. aurora known aquatic habitat data (2006-2015) were compiled by managers in City of Portland and City of Gresham and aggregated for this case study. Since 2015 there have been newly added sites with $R$. aurora presence. Additional data with presence, abundance, and occupancy information was available for some aquatic sites but not used for this case study.

List of data names, description, unit/extent, and source for Chapter 4 applications.

All Datum: GCS_North_American_1983, Projection: NAD83 UTM Zone 10N, unless otherwise specified.

\begin{tabular}{|c|c|c|c|}
\hline Data Name & Description & Unit/Extent & Source \\
\hline Aerial Imagery & $\begin{array}{l}\text { Purpose: site selection, } \\
\text { validation, and landcover } \\
\text { Data Type: Raster, Leaf on } \\
\text { aerial photos using 6" .tif } \\
\text { mosaic Portland Metro } \\
\text { region }\end{array}$ & $\begin{array}{l}\text { Resolution: } 5 \text { meter pixels } \\
\text { Extent: } \\
\text { Portland Metro, } \\
\text { * West longitude } \quad-123.486073 \\
\text { * East longitude } \quad-121.651005 \\
\text { * North latitude } \quad 45.461675 \\
\text { * South latitude } \quad 44.885714\end{array}$ & $\begin{array}{l}\text { Metro RLIS } \\
\text { (2019) }\end{array}$ \\
\hline
\end{tabular}




\begin{tabular}{|c|c|c|c|}
\hline $\begin{array}{l}\text { Boundaries } \\
\text { and Reference }\end{array}$ & $\begin{array}{l}\text { Purpose: cartographic, } \\
\text { reference layers }\end{array}$ & $\begin{array}{l}\text { Datum: } \\
\text { GCS_North_American_1983_HARN }\end{array}$ & $\begin{array}{l}\text { Metro RLIS } \\
\text { (2019) }\end{array}$ \\
\hline Layers & $\begin{array}{l}\text { Data Type: } \\
\text { City Limits, Metro boundary, } \\
\text { Orca (parks and natural } \\
\text { areas),Streams, Streets, } \\
\text { Taxlots, Trails, Wetlands, } \\
\text { urban growth boundary, } \\
\text { zoning }\end{array}$ & $\begin{array}{l}\text { Projection: } \\
\text { NAD_1983_HARN_StatePlane_Oreg } \\
\text { on_North_FIPS_3601_Feet_Intl } \\
\text { Extent: Portland Metro, } \\
\text { * West longitude }-123.158891 \\
\text { * East longitude }-122.323113 \\
\text { * North latitude } 45.665036 \\
\text { * South latitude } 45.273366\end{array}$ & $\begin{array}{l}\text { Oregon } \\
\text { Department } \\
\text { of } \\
\text { Land } \\
\text { Conservation } \\
\text { and } \\
\text { Development } \\
\text { (2016) }\end{array}$ \\
\hline Habitat Score & $\begin{array}{l}\text { Purpose: determines percent } \\
\text { habitat calculation. Distance } \\
\text { bins for adult frogs which } \\
\text { remain at wetlands } \\
\text { herbaceous, forest, or urban } \\
\text { habitat that include these } \\
\text { microhabitat type within } \\
\text { each } 500 \text { m HCZ. Used for } \\
\text { occurrence density. } \\
\text { Data Type: Data table, GIS } \\
\text { and Field-derived collection } \\
\text { and scorecard results }\end{array}$ & $\begin{array}{l}\text { Extent: } \\
\text { Gresham East Buttes, } \\
\text { *West longitude }-122.498315 \text {, } \\
\text { *East longitude }-122.396333 \text {, } \\
\text { *North latitude } 45.502255 \\
\text { *South latitude } 45.451742 \text {, }\end{array}$ & $\begin{array}{l}\text { Field } \\
\text { Collection- } \\
\text { Metro Toolkit } \\
\text { Habitat } \\
\text { Assessment } \\
\text { Surveys } \\
2018 \text { (PSU- } \\
\text { Metro 2018) }\end{array}$ \\
\hline $\begin{array}{l}\text { Landcover } \\
\text { and terrestrial } \\
\text { habitat }\end{array}$ & $\begin{array}{l}\text { Purpose: site selection, } \\
\text { habitat and barrier } \\
\text { assessment, } \\
\text { frog species model, } \\
\text { impedance values, } \\
\text { Classes: Ivl0, Ivl1, Ivl2 } \\
\text { Data Type: Raster, Leaf on } \\
\text { land cover dataset in .gdb } \\
\text { format } \\
\text { Purpose: Core terrestrial } \\
\text { habitat, development } \\
\text { percentage }\end{array}$ & $\begin{array}{l}\text { RLIS_veg RCS Intertwine } \\
\text { Resolution: } 5 \text { meter pixels } \\
\text { Extent: Portland Metro, } \\
\text { * West longitude }-123.421461 \\
\text { * East longitude }-122.029092 \\
\text { * North latitude } 46.049451 \\
\text { * South latitude } 45.017069 \\
\text { Oregon StateWide Habitat Map } \\
\text { Resolution: } 30 \text { meter pixels } \\
\text { resampled to } 5 \text { meter pixels } \\
\text { Datum: D_North_American_1983 } \\
\text { Projection: GRS_1980 } \\
\text { Extent: } \\
\text { Oregon State extent clipped to } \\
\text { Portland Metro, } \\
\text { *West longitude -125.022412921 }\end{array}$ & $\begin{array}{l}\text { Regional } \\
\text { Conservation } \\
\text { Strategy (RCS- } \\
\text { INR 2012) } \\
\text { Oregon } \\
\text { StateWide } \\
\text { Habitat Map } \\
\text { (PSU-INR } \\
\text { 2018) }\end{array}$ \\
\hline
\end{tabular}


* East longitude -116.134029843

*North latitude: 46.384468141

*South latitude: 41.91162369

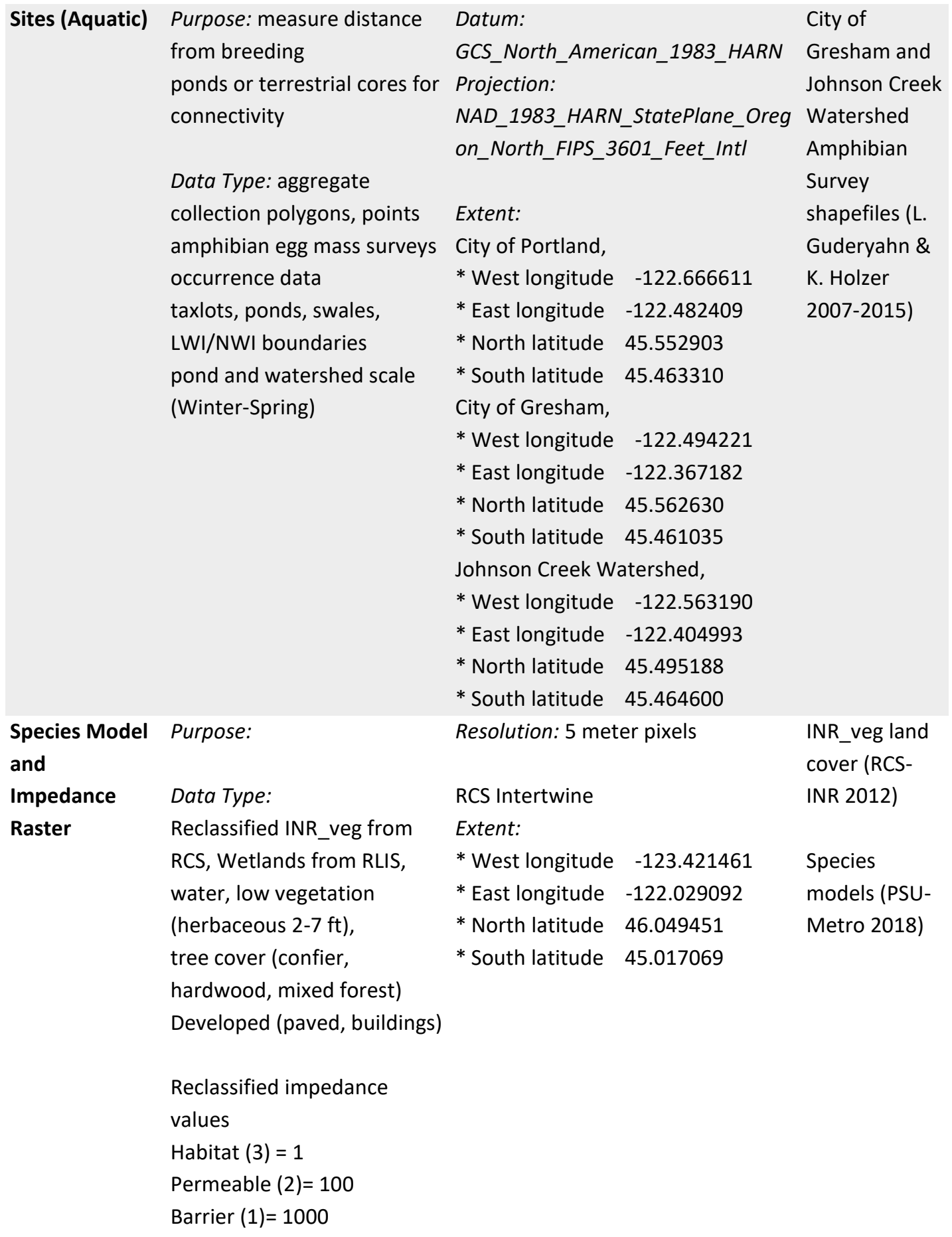




\section{Appendix B:}

Forms

\section{B.1 Habitat Assessment Sheets (PSU-Metro 2018)}

\section{Habitat Assessment}

Site name/ coordinates:

Date \& time of field survey:

Recorder:

Aerial photo year \& season:

\begin{tabular}{|c|c|c|c|c|}
\hline & Characteristic & $\begin{array}{l}\text { Field data category options } \\
\text { (to be verified [GIS data] and measured [field data] } \\
\text { by technicians on site) }\end{array}$ & Verification & $\begin{array}{l}\text { Estimate } \\
\text { by: }\end{array}$ \\
\hline \multirow{6}{*}{$\begin{array}{l}\text { Connectivity } \\
\text { patch and } \\
\text { matrix } \\
\text { characteristics }\end{array}$} & Land Ownership/Zoning & (marked on accompanying aerial photo) & $\begin{array}{l}\text { Yes / No } \\
\text { Correction: }\end{array}$ & $\begin{array}{l}\square \text { Field } \\
\text { observat } \\
\square \text { Aerial ph }\end{array}$ \\
\hline & Dominant matrix type & $\begin{array}{l}\text { Agriculture __ } \% \\
\text { Developed __ } \%\end{array}$ & $\begin{array}{l}\text { Yes / No } \\
\text { Correction: }\end{array}$ & $\begin{array}{l}\square \text { Field } \\
\text { observat } \\
\square \text { Aerial ph } \\
\end{array}$ \\
\hline & Dominate matrix type & $\begin{array}{l}\text { Agriculture type (low crop, orchard, corn etc.) } \\
\text { Developed type (residential, commercial, industrial) }\end{array}$ & & $\begin{array}{l}\square \text { Field } \\
\square \text { Aerial ph }\end{array}$ \\
\hline & $\begin{array}{l}\text { Minimum width of natural } \\
\text { land cover (non-matrix) }\end{array}$ & _ Meters & $\begin{array}{l}\text { Yes / No } \\
\text { Correction: }\end{array}$ & $\begin{array}{l}\square \text { Field } \\
\text { observat } \\
\square \text { Aerial ph }\end{array}$ \\
\hline & $\begin{array}{l}\text { \% Hardscaping (roads, parking lots } \\
\text { etc. does not include structures) }\end{array}$ & $\begin{array}{l}\text { Hardscaping (impervious, not including structures) } \\
\quad \%\end{array}$ & $\begin{array}{l}\text { Yes / No } \\
\text { Correction: }\end{array}$ & $\begin{array}{l}\square \text { Field } \\
\text { observat } \\
\square \text { Aerial ph } \\
\end{array}$ \\
\hline & $\%$ Structures & $\begin{array}{l}\text { Structures } \\
\ldots\end{array}$ & $\begin{array}{l}\text { Yes / No } \\
\text { Correction: }\end{array}$ & $\begin{array}{l}\square \text { Field } \\
\text { observat } \\
\square \text { Aerial ph }\end{array}$ \\
\hline \multirow[t]{7}{*}{ Water source } & $\begin{array}{l}\text { Water source within } \\
\text { connectivity zone? }\end{array}$ & $\begin{array}{l}\text { Yes / No } \\
\text { Type: stream pond }\end{array}$ & $\begin{array}{l}\text { Yes / No } \\
\text { Correction: }\end{array}$ & $\begin{array}{l}\square \text { Field } \\
\text { observat } \\
\square \text { Aerial ph }\end{array}$ \\
\hline & $\begin{array}{l}\text { Open water \% cover and } \\
\text { distribution }\end{array}$ & $\begin{array}{l}\text { Open water } \\
\text { Fragmented }\end{array}$ & $\begin{array}{l}\text { Yes / No } \\
\text { Correction: }\end{array}$ & $\begin{array}{l}\square \text { Field } \\
\text { observat } \\
\text { Aerial ph }\end{array}$ \\
\hline & $\begin{array}{r}\begin{array}{r}\text { Distance of HCZ edge from } \\
\text { water }\end{array}\end{array}$ & $\begin{array}{l}\text { If answer to water source is no then report distance } \\
\text { to water here: __ Meters }\end{array}$ & $\begin{array}{l}\text { Yes / No } \\
\text { Correction: }\end{array}$ & $\begin{array}{l}\square \text { Field } \\
\text { observat } \\
\square \text { Aerial ph }\end{array}$ \\
\hline & Seasonality & Ephemeral Intermittent Perennial & & $\begin{array}{l}\square \text { Field } \\
\text { observat } \\
\square \text { Aerial ph } \\
\end{array}$ \\
\hline & Channel stability (streams) & Straight or Meandering & & $\begin{array}{l}\text { Field } \\
\text { observat } \\
\square \text { Aerial ph } \\
\end{array}$ \\
\hline & Bank condition (streams) & Incised or sloped & & $\begin{array}{l}\square \text { Field } \\
\text { observat } \\
\square \text { Aerial ph } \\
\end{array}$ \\
\hline & Substrate & Substrate (sediment, cobble, veg, rip rap, concrete) & & $\begin{array}{l}\square \text { Field } \\
\text { observat } \\
\square \text { Aerial ph } \\
\end{array}$ \\
\hline \multirow[t]{5}{*}{ Vegetation } & $\begin{array}{l}\text { Conifer forest \% cover and } \\
\text { distribution }\end{array}$ & $\begin{array}{l}\text { Conifer Forest } \\
\text { Fragmented / Contiguous }\end{array}$ & $\begin{array}{l}\text { Yes / No } \\
\text { Correction: }\end{array}$ & $\begin{array}{l}\square \text { Field } \\
\text { observat } \\
\square \text { Aerial ph }\end{array}$ \\
\hline & $\begin{array}{l}\text { Deciduous forest \% cover and } \\
\text { distribution }\end{array}$ & $\begin{array}{l}\text { Deciduous Forest__\% } \\
\text { Fragmented / Contiguous }\end{array}$ & $\begin{array}{l}\text { Yes / No } \\
\text { Correction: }\end{array}$ & $\begin{array}{l}\square \text { Field } \\
\text { observat } \\
\square \text { Aerial ph } \\
\end{array}$ \\
\hline & $\begin{array}{l}\text { Oak woodland \% cover and } \\
\text { distribution }\end{array}$ & $\begin{array}{l}\text { Oak Woodland } \\
\text { Fragmented / Contiguous }\end{array}$ & $\begin{array}{l}\text { Yes / No } \\
\text { Correction: }\end{array}$ & $\begin{array}{l}\text { Field } \\
\text { observat } \\
\square \text { Aerial ph } \\
\end{array}$ \\
\hline & Maximum canopy gap (trees) & Meters & $\begin{array}{l}\text { Yes / No } \\
\text { Correction: }\end{array}$ & $\begin{array}{l}\text { Field } \\
\text { observat } \\
\square \text { Aerial ph } \\
\end{array}$ \\
\hline & $\begin{array}{l}\text { Riparian area/Woody species } \\
\text { along stream (if present) }\end{array}$ & _ $\%$ cover & $\begin{array}{l}\text { Yes / No } \\
\text { Correction: }\end{array}$ & $\begin{array}{l}\square \text { Field } \\
\text { observat } \\
\square \text { Aerial ph } \\
\end{array}$ \\
\hline
\end{tabular}




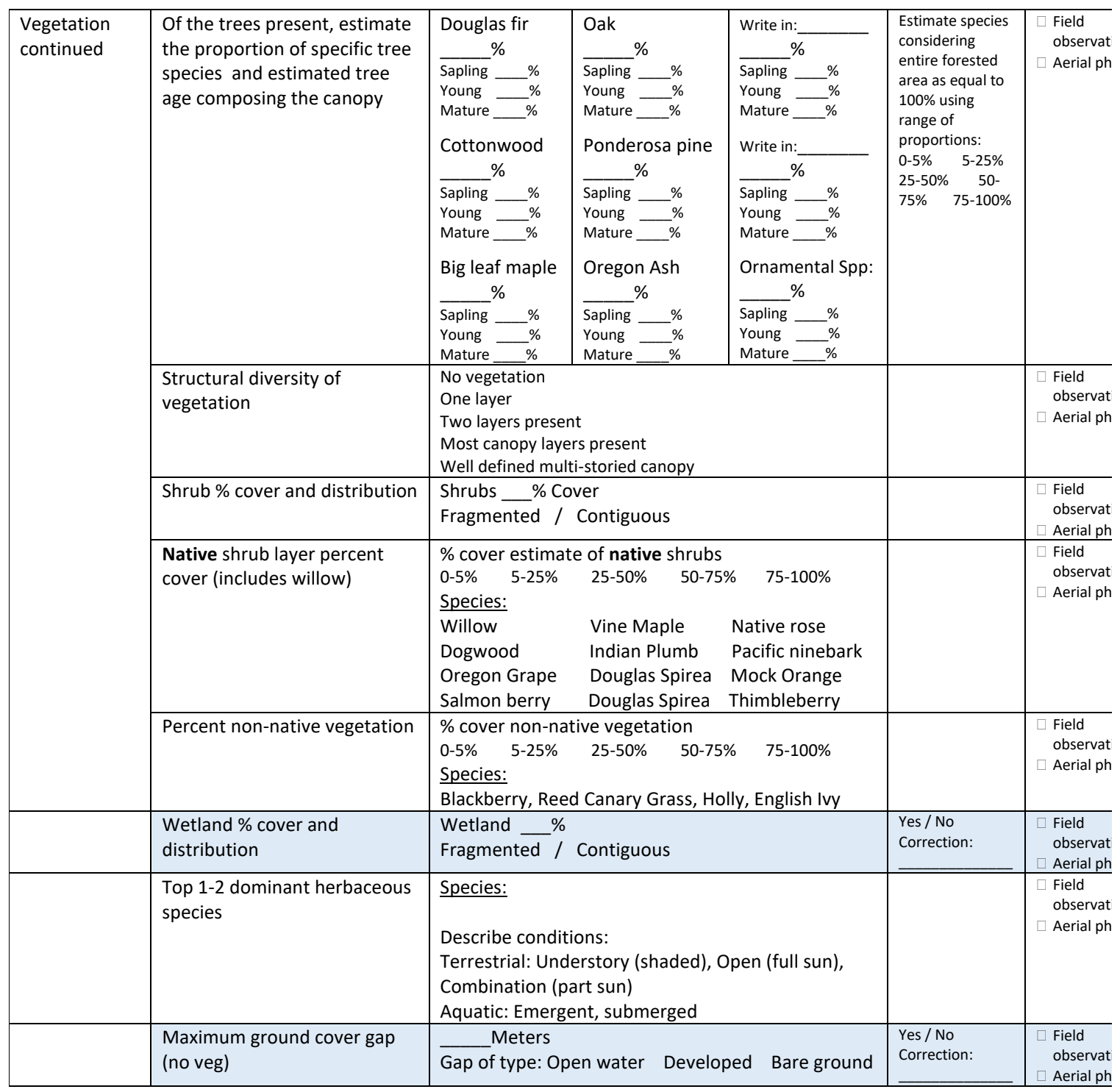




\begin{tabular}{|c|c|c|c|c|c|}
\hline \multirow[t]{4}{*}{$\begin{array}{l}\text { Other } \\
\text { structural } \\
\text { components }\end{array}$} & Downed wood & $\begin{array}{l}\frac{\text { Logs }}{\text { High density }} \\
\text { Medium density } \\
\text { Low density } \\
\text { Not Visible } \\
\text { None }\end{array}$ & $\begin{array}{l}\text { Branches } \\
\text { High density } \\
\text { Medium } \\
\text { density } \\
\text { Low density } \\
\text { Not Visible } \\
\text { None }\end{array}$ & $\begin{array}{l}\text { Rootwad/Stumps } \\
\text { High density } \\
\text { Medium density } \\
\text { Low density } \\
\text { Not Visible } \\
\text { None }\end{array}$ & $\begin{array}{l}\square \text { Field } \\
\text { observat } \\
\square \text { Aerial ph }\end{array}$ \\
\hline & Snags & \multicolumn{3}{|c|}{$\begin{array}{l}\text { Yes / No / Not Visible } \\
\text { If yes describe (abundance, height and dbh species } \\
\text { and grade of decay where possible) }\end{array}$} & $\begin{array}{l}\text { Field } \\
\text { observat } \\
\square \text { Aerial ph }\end{array}$ \\
\hline & $\begin{array}{l}\text { Talus slopes/rock piles } \\
\text { (reptiles) }\end{array}$ & \multicolumn{3}{|c|}{$\begin{array}{l}\text { Yes / No / Not Visible } \\
\text { If yes, in flooded area? Yes/No } \\
\text { If yes, receiving sun (south facing slope?)/percent } \\
\text { cover above? }\end{array}$} & $\begin{array}{l}\square \text { Field } \\
\text { observat } \\
\square \text { Aerial ph }\end{array}$ \\
\hline & Duff layer/Thatch & \multicolumn{3}{|c|}{$\begin{array}{l}\text { Not Visible } \\
<10 \mathrm{~cm} \text { partially decomposed } \\
>10 \mathrm{~cm} \text { partially decomposed }\end{array}$} & $\begin{array}{r}\square \text { Field } \\
\text { observat } \\
\square \text { Aerial ph }\end{array}$ \\
\hline $\begin{array}{l}\text { Wildlife } \\
\text { observations }\end{array}$ & $\begin{array}{l}\text { Wildlife sign and observations } \\
\text { in the field } \\
\text { (tracks, droppings burrows, etc.) }\end{array}$ & \multicolumn{3}{|c|}{ List species \& associated sign: } & $\begin{array}{l}\square \text { Field } \\
\text { observat } \\
\square \text { Aerial ph }\end{array}$ \\
\hline \multirow[t]{3}{*}{$\begin{array}{l}\text { Human } \\
\text { disturbance }\end{array}$} & $\begin{array}{l}\text { Use by pets or domestic } \\
\text { animals }\end{array}$ & \multicolumn{3}{|c|}{$\begin{array}{l}\text { Describe and rate intensity: } \\
\text { No evidence, Some evidence, } \\
\text { Regular use apparent } \\
\text { Describe: }\end{array}$} & $\begin{array}{l}\square \text { Field } \\
\text { observat } \\
\square \text { Aerial ph }\end{array}$ \\
\hline & $\begin{array}{l}\text { Trails/other evidence of } \\
\text { regular human } \\
\text { presence/activity }\end{array}$ & \multicolumn{3}{|c|}{$\begin{array}{l}\text { Describe and rate intensity of trail use: } \\
\text { No evidence, Some evidence, } \\
\text { Regular use apparent } \\
\text { Describe: }\end{array}$} & $\begin{array}{l}\square \text { Field } \\
\text { observat } \\
\square \text { Aerial ph }\end{array}$ \\
\hline & $\begin{array}{l}\text { Specific activities that may } \\
\text { influence wildlife movements } \\
\text { (attraction to refuse, avoidance of } \\
\text { industrial activities, noise) }\end{array}$ & \multicolumn{3}{|c|}{$\begin{array}{l}\text { Describe and rate intensity of human activity: } \\
\text { Zero Light Moderate Heavy } \\
\text { Describe: }\end{array}$} & $\begin{array}{l}\text { Field } \\
\text { observat } \\
\square \text { Aerial ph }\end{array}$ \\
\hline
\end{tabular}




\section{B.2 Species Scorecard (Northern Red-legged Frog, Rana aurora) (PSU-Metro 2018)}

\begin{tabular}{|c|c|c|c|}
\hline \multicolumn{4}{|c|}{ Habitat Scoring Rubric for - Red-Legged Frog } \\
\hline & Characteristic & Field data category options & Scoring Values \\
\hline \multirow{7}{*}{$\begin{array}{l}\text { Connectivity } \\
\text { patch and } \\
\text { matrix } \\
\text { characteristics }\end{array}$} & Land Ownership/Zoning & (marked on accompanying aerial photo) & \\
\hline & Dominant matrix type & $\begin{array}{l}\text { Agriculture } \_\% \\
\text { Developed } \_\%\end{array}$ & $\begin{array}{l}\text { Develc } \\
\text { ed } \\
<10 \% \\
10-25 \% \\
2 \\
26-50 \% \\
1 \\
51-100 \\
: 0 \\
\end{array}$ \\
\hline & Dominate matrix type & $\begin{array}{l}\text { Agriculture type (low crop, orchard, corn etc.) } \\
\text { Developed type (residential, commercial, industrial) }\end{array}$ & $\begin{array}{l}\text { Dev } \\
\text { type: } \\
\text { Reside } \\
\text { ial: } 1 \\
\text { Comm } \\
\text { cial: } 0 \\
\text { Indust } \\
\text { I: } 0 \\
\end{array}$ \\
\hline & & & Apply Importance Multiplier: 7 \\
\hline & $\begin{array}{l}\text { Minimum width of natural } \\
\text { land cover (non-matrix) }\end{array}$ & Meters & $\begin{array}{l}0: 0 \\
<15 \mathrm{~m}: 1 \\
15-50 \mathrm{~m}: 2 \\
>50 \mathrm{~m}: 3 \\
\text { Apply Importance Multiplier: } 6\end{array}$ \\
\hline & $\begin{array}{l}\text { \% Hardscaping (roads, parking lots } \\
\text { etc. does not include structures) }\end{array}$ & $\begin{array}{l}\text { Hardscaping (impervious, not including structures) } \\
\ldots \%\end{array}$ & $\begin{array}{l}>25 \%: 0 \\
20-25 \%: 1 \\
10-20 \%: 2 \\
<10 \%: 3 \\
\text { Apply Importance Multiplier: } 8\end{array}$ \\
\hline & \% Structures & $\begin{array}{l}\text { Structures } \\
\ldots \%\end{array}$ & $\begin{array}{l}>50 \%: 0 \\
25-50 \%: 1 \\
10-25 \%: 2 \\
<10 \%: 3 \\
\end{array}$ \\
\hline \multirow[t]{8}{*}{ Water source } & $\begin{array}{l}\text { Water source within } \\
\text { connectivity zone? }\end{array}$ & $\begin{array}{l}\text { Yes / No } \\
\text { Type: stream pond }\end{array}$ & $\begin{array}{l}\text { Yes: } \\
\text { Stream } 1 \\
\text { Pond } 3\end{array}$ \\
\hline & \multirow[t]{2}{*}{$\begin{array}{l}\text { Open water \% cover and } \\
\text { distribution }\end{array}$} & Open water __ $\%$ & $\begin{array}{l}0-10 \%: 1 \\
10-50 \%: 3 \\
50-75 \%: 2 \\
>75 \% 1 \\
\text { Apply Importance Multiplier: } 7\end{array}$ \\
\hline & & Fragmented / Contiguous & $\begin{array}{l}\text { Fragmented: } 3 \\
\text { Contiguous: } 1\end{array}$ \\
\hline & $\begin{array}{r}\text { Distance of HCZ edge from } \\
\text { water }\end{array}$ & $\begin{array}{l}\text { If answer to water source is no then report distance } \\
\text { to water here: }\end{array}$ & $\begin{array}{l}>300 \mathrm{~m}: 1 \\
50-299 \mathrm{~m}: 2 \\
\text { If }<50 \mathrm{~m}: 3\end{array}$ \\
\hline & Seasonality & Ephemeral Intermittent Perennial & $\begin{array}{l}\text { Perennial: } 1 \\
\text { Intermittent: } 2 \\
\text { Ephemeral: } 3 \\
\text { Apply Importance Multiplier: } 8 \\
\end{array}$ \\
\hline & Channel stability (streams) & Straight or Meandering & $\mathrm{N} / \mathrm{S}$ \\
\hline & Bank condition (streams) & Incised or sloped & $\begin{array}{l}\text { Sloped: } 3 \\
\text { Incised: } 1\end{array}$ \\
\hline & Substrate & Substrate (sediment, cobble, veg, rip rap, concrete) & $\begin{array}{l}\text { Aquatic Veg: } 3 \\
\text { Sediment: } 2 \\
\text { Other: } 1\end{array}$ \\
\hline \multirow[t]{2}{*}{ Vegetation } & $\begin{array}{l}\text { Conifer forest \% cover and } \\
\text { distribution }\end{array}$ & Conifer Forest __ $\%$ & $\begin{array}{l}10-50 \%: 2 \\
50-75 \%: 3 \\
75-90 \% 2 \\
>90 \%: 1 \\
\text { Apply Importance Multiplier: } 7\end{array}$ \\
\hline & & Fragmented / Contiguous & $\begin{array}{l}\text { Fragmented: } 1 \\
\text { Contiguous: } 3\end{array}$ \\
\hline
\end{tabular}




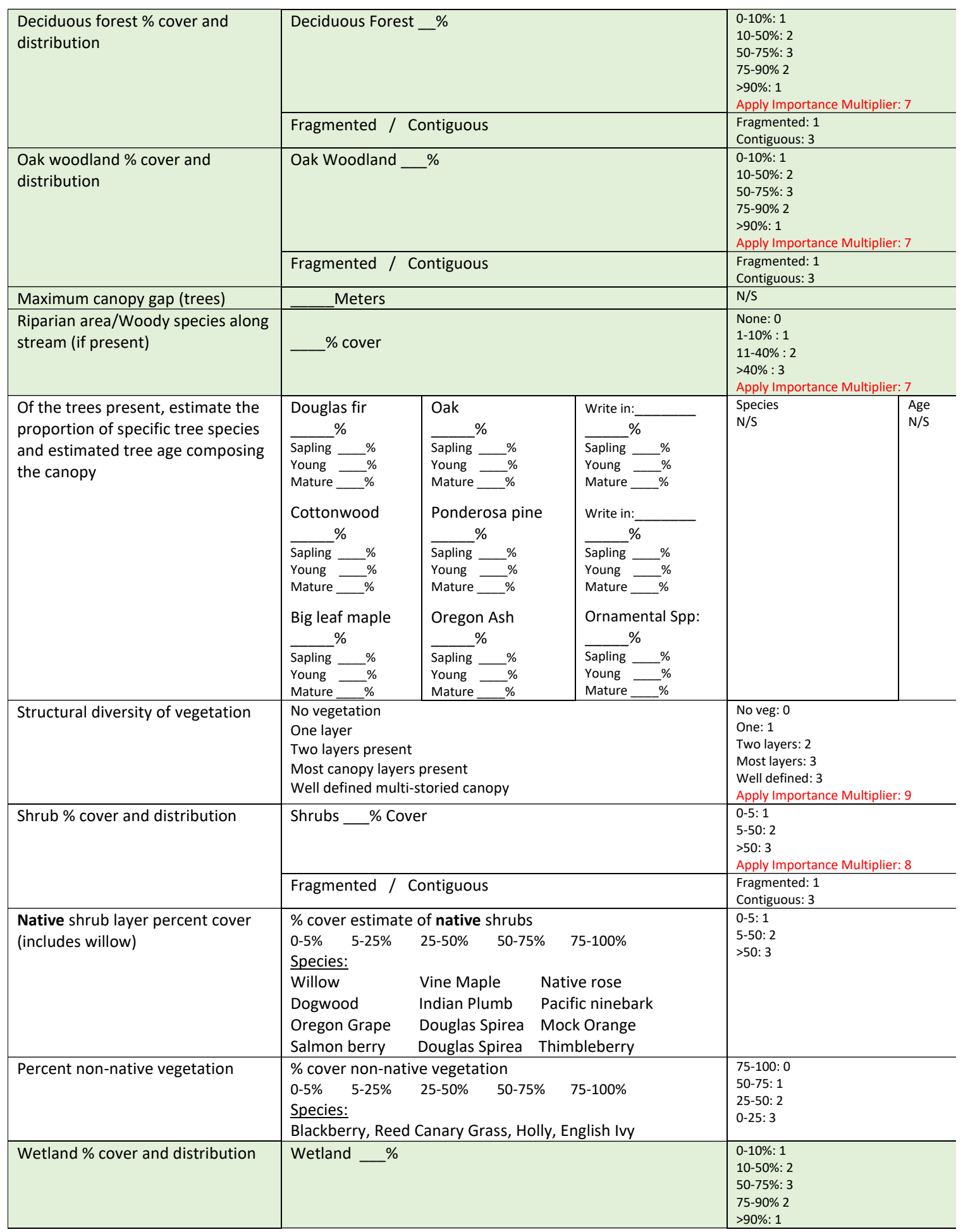




\begin{tabular}{|c|c|c|c|c|c|}
\hline \multicolumn{3}{|l|}{ Fragmented / Contiguous } & \multicolumn{3}{|l|}{$\mathrm{N} / \mathrm{S}$} \\
\hline \multicolumn{3}{|c|}{$\begin{array}{l}\text { Species: } \\
\text { Describe conditions: } \\
\text { Terrestrial: Understory (shaded), Open (full sun), Combination (part sun) } \\
\text { Aquatic: Emergent, submerged }\end{array}$} & \multicolumn{3}{|c|}{$\begin{array}{l}\text { Terrestrial } \\
\text { Open: } 1 \\
\text { Combination: } 3 \\
\text { Shaded: } 3 \\
\text { Aquatic } \\
\text { Emergent: } 3 \\
\text { Submerged: } 3 \\
\text { Apply Importance Multiplier: } 8\end{array}$} \\
\hline \multicolumn{3}{|c|}{$\begin{array}{l}\text { Meters } \\
\text { Gap of type: Open water Developed Bare ground }\end{array}$} & $\begin{array}{l}\text { Open Water } \\
>50 \mathrm{~m}: 1 \\
25-50 \mathrm{~m}: 2 \\
<25 \mathrm{~m}: 3\end{array}$ & $\begin{array}{l}\text { Dev: } \\
>35 \mathrm{~m}: 0 \\
35-15 \mathrm{~m}: 1 \\
14-5 \mathrm{~m}: 2 \\
<5 \mathrm{~m}: 3\end{array}$ & $\begin{array}{l}\text { Bare ground: } \\
>75: 0 \\
50-75 \mathrm{~m}: 1 \\
50-25 \mathrm{~m}: 2 \\
<25 \mathrm{~m}: 3\end{array}$ \\
\hline $\begin{array}{l}\frac{\text { Logs }}{\text { High density }} \\
\text { Medium density } \\
\text { Low density } \\
\text { Not Visible } \\
\text { None }\end{array}$ & $\begin{array}{l}\text { Branches } \\
\text { High density } \\
\text { Medium density } \\
\text { Low density } \\
\text { Not Visible } \\
\text { None }\end{array}$ & $\begin{array}{l}\text { Rootwad/Stumps } \\
\text { High density } \\
\text { Medium density } \\
\text { Low density } \\
\text { Not Visible } \\
\text { None }\end{array}$ & \multicolumn{3}{|c|}{$\begin{array}{l}\text { Any type: } \\
\text { High: } 3 \\
\text { Med: } 2 \\
\text { Low: } 1 \\
\text { None: } 0 \\
\text { Apply Importance Multiplier: } 6\end{array}$} \\
\hline \multicolumn{3}{|c|}{$\begin{array}{l}\text { Yes / No / Not Visible } \\
\text { If yes describe (abundance, height and dbh species and grade of decay where } \\
\text { possible) }\end{array}$} & \multicolumn{3}{|l|}{$\mathrm{N} / \mathrm{S}$} \\
\hline \multicolumn{3}{|c|}{$\begin{array}{l}\text { Yes / No / Not Visible } \\
\text { If yes, in flooded area? Yes/No } \\
\text { If yes, receiving sun (south facing slope?)/percent cover above? }\end{array}$} & \multicolumn{3}{|l|}{$\mathrm{N} / \mathrm{S}$} \\
\hline \multicolumn{3}{|l|}{$\begin{array}{l}\text { Not Visible } \\
<10 \mathrm{~cm} \text { partially decomposed } \\
>10 \mathrm{~cm} \text { partially decomposed }\end{array}$} & \multicolumn{3}{|c|}{$\begin{array}{l}\text { None: } 0 \\
<10 \mathrm{~cm}: 1 \\
>10 \mathrm{~cm}: 3 \\
\text { Apply Importance Multiplier: } 6\end{array}$} \\
\hline \multicolumn{3}{|l|}{ List species \& associated sign: } & \multicolumn{3}{|c|}{$\begin{array}{l}\text { If Red Legged Frog or other native amphibians: } 3 \\
\text { Non-Native Amphibians: } 2 \\
\text { Any: } 1 \\
\text { None } 0\end{array}$} \\
\hline \multicolumn{3}{|l|}{$\begin{array}{l}\text { Describe and rate intensity: } \\
\text { No evidence, Some evidence, } \\
\text { Regular use apparent } \\
\text { Describe: }\end{array}$} & \multicolumn{3}{|c|}{$\begin{array}{l}\text { Heavy: } 0 \\
\text { Regular: } 1 \\
\text { Some: } 2 \\
\text { None: } 3 \\
\text { Apply Importance Multiplier: } 5\end{array}$} \\
\hline \multicolumn{3}{|c|}{$\begin{array}{l}\text { Describe and rate intensity of trail use: } \\
\quad \text { No evidence, Some evidence, } \\
\text { Regular use apparent } \\
\text { Describe: }\end{array}$} & \multicolumn{3}{|c|}{$\begin{array}{l}\text { Heavy: } 0 \\
\text { Regular: } 1 \\
\text { Some: } 2 \\
\text { None: } 3 \\
\text { Apply Importance Multiplier: } 5\end{array}$} \\
\hline \multicolumn{3}{|c|}{$\begin{array}{l}\text { Describe and rate intensity of human activity: } \\
\text { Zero Light Moderate Heavy } \\
\text { Describe: }\end{array}$} & \multicolumn{3}{|c|}{$\begin{array}{l}\text { Heavy: } 0 \\
\text { Moderate: } 1 \\
\text { Light: } 2 \\
\text { Zero: } 3 \\
\text { Apply Importance Multiplier: } 5\end{array}$} \\
\hline
\end{tabular}




\section{Appendix C: \\ Additional Data}

C.1 Resistance Layer Model Parameters (Circuitscape, Northern Red-Legged Frog)

PSU-Metro. In Progress. Adapted from Martin Lafrenz, PhD

Parameters for the Northern Red-legged frog Species Model

\begin{tabular}{|l|l|}
\hline GIS Layer & Habitat Parameters \\
\hline Conifer Density & $>50 \%$, medium tall to very tall \\
\hline Hardwood Density & $>50 \%$, any size class \\
\hline Oak Density & NA \\
\hline Herbaceous/Shrub & All, any size class \\
\hline Open Water & $\begin{array}{l}\text { Slow water (updated to include } \\
\text { stormwater detention ponds and } \\
\text { known aquatic breeding habitat for } \\
\text { R. aurora in 2019) }\end{array}$ \\
\hline Wetlands & All \\
\hline Maximum Distance from Water (m) & 200 m (updated to 500 m in 2019) \\
\hline Maximum Canopy Gap & NA \\
\hline $\begin{array}{l}\text { Maximum Ground Cover Gap (no vegetation) } \\
\text { m) }\end{array}$ & 50 m (updated to NA in 2019) \\
\hline
\end{tabular}




\begin{tabular}{|l|l|}
\hline GIS Layer & Barrier Parameters \\
\hline Paved & Any \\
\hline Buildings & Any \\
\hline Development Density & $\begin{array}{l}\text { TBD (updated to urban } \\
\text { development intensity type in 2019) }\end{array}$ \\
\hline Barren (e.g. Quarry) & Any \\
\hline Open Water: Distance from Shore (m) & $\begin{array}{l}\text { None (updated barriers to large } \\
\text { open streams like the Willamette } \\
\text { River 2019) }\end{array}$ \\
\hline Wetlands & NA \\
\hline Distance fromWater (m) & NA \\
\hline Canopy Gap (m) & NA \\
\hline Ground Cover Gap (no vegetation) (m) & 75 m (updated to 70 m in 2019) \\
\hline
\end{tabular}


C.2 Raw GIS and Field Score, Spearman's Rank (Gresham East Buttes, Oregon)

\begin{tabular}{|c|c|c|c|c|c|c|}
\hline $\begin{array}{l}\text { Habitat Connectivity } \\
\text { Zone }\end{array}$ & Development \% & GIS Score & Field Score & Difference & GIS (rank) & Field (ran \\
\hline 15 & 0 & 61 & 50 & 11 & 10 & 37 \\
\hline 24 & 1 & 59 & 71 & 12 & 13.5 & 3 \\
\hline 38 & 1 & 62 & 58 & 4 & 7.5 & 25 \\
\hline 36 & 2 & 66 & 56 & 10 & 3.5 & 29.5 \\
\hline 35 & 3 & 74 & 58 & 16 & 1 & 25 \\
\hline 14 & 6 & 60 & 58 & 2 & 12 & 25 \\
\hline 25 & 9 & 62 & 69 & 7 & 7.5 & 6.5 \\
\hline 21 & 12 & 66 & 68 & 2 & 3.5 & 8.5 \\
\hline 40 & 15 & 58 & 70 & 12 & 15.5 & 4.5 \\
\hline 39 & 16 & 61 & 75 & 14 & 10 & 2 \\
\hline 3 & 17 & 58 & 66 & 8 & 15.5 & 13 \\
\hline 11 & 17 & 66 & 61 & 5 & 3.5 & 20 \\
\hline 18 & 17 & 66 & 54 & 12 & 3.5 & 34 \\
\hline 37 & 17 & 54 & 57 & 3 & 26 & 28 \\
\hline 22 & 19 & 65 & 62 & 3 & 6 & 18.5 \\
\hline 34 & 25 & 61 & 63 & 2 & 10 & 16 \\
\hline 23 & 41 & 55 & 68 & 13 & 23 & 8.5 \\
\hline 20 & 46 & 55 & 59 & 4 & 23 & 22 \\
\hline 28 & 46 & 57 & 66 & 9 & 17.5 & 13 \\
\hline 2 & 49 & 59 & 69 & 10 & 13.5 & 6.5 \\
\hline 4 & 53 & 55 & 58 & 3 & 23 & 25 \\
\hline 19 & 53 & 56 & 56 & 0 & 19.5 & 29.5 \\
\hline 27 & 53 & 50 & 67 & 17 & 29.5 & 10.5 \\
\hline 26 & 54 & 50 & 58 & 8 & 29.5 & 25 \\
\hline 17 & 56 & 56 & 51 & 5 & 19.5 & 35.5 \\
\hline 1 & 61 & 53 & 79 & 26 & 27.5 & 1 \\
\hline 29 & 66 & 47 & 63 & 16 & 31.5 & 16 \\
\hline 16 & 72 & 55 & 44 & 11 & 23 & 38.5 \\
\hline 30 & 73 & 44 & 67 & 23 & 34.5 & 10.5 \\
\hline 10 & 78 & 57 & 60 & 3 & 17.5 & 21 \\
\hline 8 & 81 & 41 & 55 & 14 & 38 & 32 \\
\hline 5 & 84 & 45 & 62 & 17 & 33 & 18.5 \\
\hline 12 & 87 & 43 & 51 & 8 & 36 & 35.5 \\
\hline 13 & 87 & 47 & 37 & 10 & 31.5 & 40 \\
\hline 7 & 88 & 44 & 55 & 11 & 34.5 & 32 \\
\hline 31 & 90 & 53 & 70 & 17 & 27.5 & 4.5 \\
\hline 9 & 93 & 42 & 55 & 13 & 37 & 32 \\
\hline 33 & 94 & 32 & 66 & 34 & 39 & 13 \\
\hline 32 & 96 & 55 & 63 & 8 & 23 & 16 \\
\hline 6 & 98 & 27 & 44 & 17 & 40 & 38.5 \\
\hline
\end{tabular}


C.3 Scorecard Sensitivity Habitat Characteristics Results (Forest Park, Oregon)

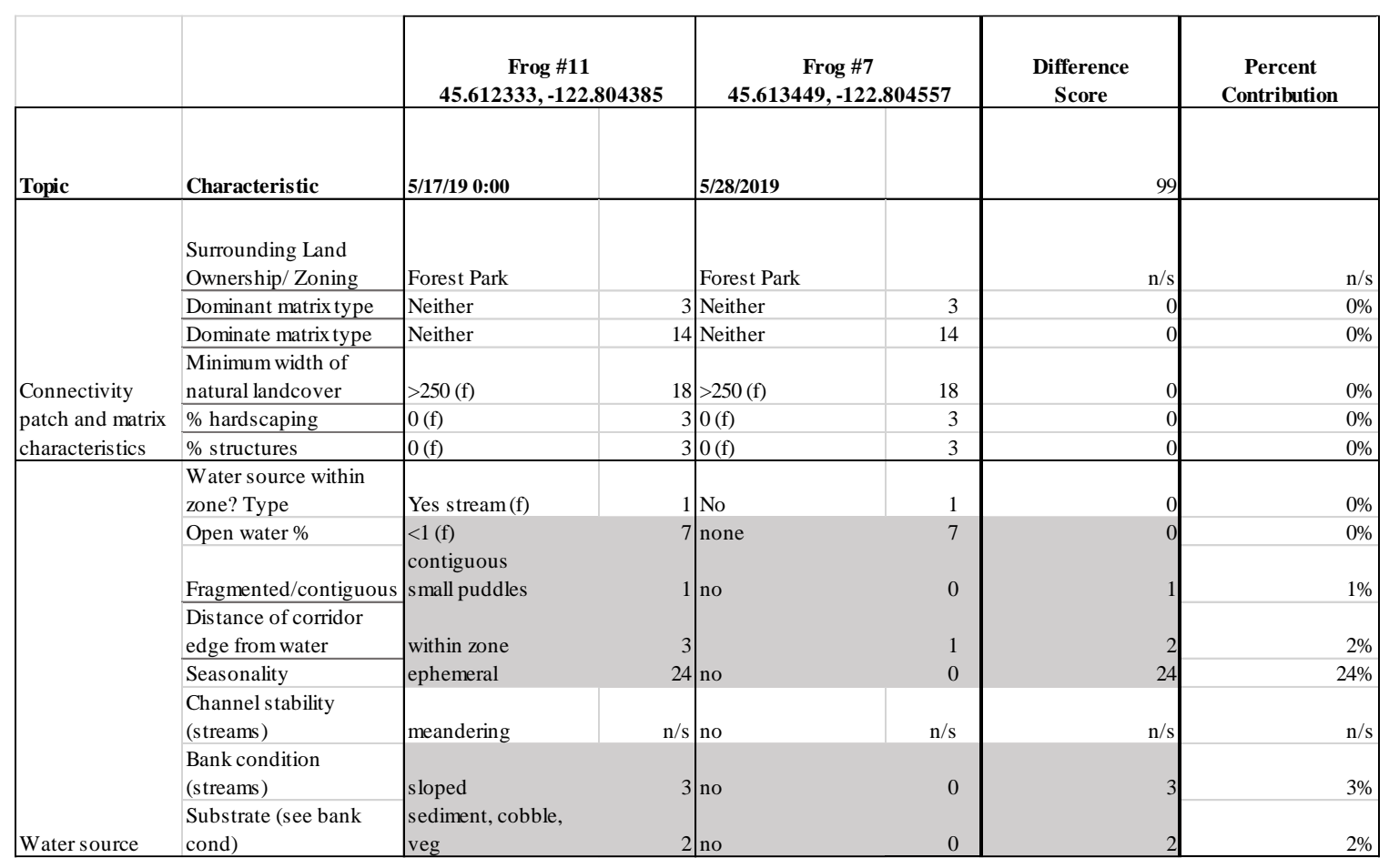




\begin{tabular}{|c|c|c|c|c|c|c|c|}
\hline & Conifer Forest $\%$ & $25-50(\mathrm{f})$ & & 70 & 21 & 7 & $7 \%$ \\
\hline & Frag/contig & contig & 3 & contig & 3 & 0 & $0 \%$ \\
\hline & Deciduous Forest \% & $\begin{array}{l}20-30(\mathrm{f}) \\
\text { ravine }=50-100\end{array}$ & & 30 & 14 & 0 & $0 \%$ \\
\hline & Frag/contig & contig & 3 & contig & 3 & 0 & $0 \%$ \\
\hline & $\begin{array}{l}\text { Maximum canopy gap } \\
\text { (trees) }\end{array}$ & 100 & $\mathrm{n} / \mathrm{s}$ & $5-7$ & $\mathrm{n} / \mathrm{s}$ & $\mathrm{n} / \mathrm{s}$ & $\mathrm{n} / \mathrm{s}$ \\
\hline & $\begin{array}{l}\text { Riparian area/Woody } \\
\text { species along stream (if } \\
\text { present) }\end{array}$ & 100 & 21 & no & 0 & 21 & $21 \%$ \\
\hline & $\begin{array}{l}\% \text { cover of specific tree } \\
\text { species and estimated } \\
\text { tree age }\end{array}$ & $\begin{array}{l}\text { Doug tir 5-25\% (M } \\
100 \text { ) } \\
\text { Cotton 0\% } \\
\text { Big leaf Maple 25- } \\
50 \% \text { (S } 75 \text { Y 20, M } \\
10 \text { ) } \\
\text { Oak 0\% } \\
\text { Ponderosa 0\% } \\
\text { Or Ash 0\% } \\
\text { Hemlock 0-5\% (S \& }\end{array}$ & $\mathrm{n} / \mathrm{s}$ & $\begin{array}{l}\text { Doug fir 60\% (S 5-10 } \\
\text { Y 30 M 60-65) } \\
\text { Cotton 0\% } \\
\text { Big leaf Maple 30\% } \\
\text { (S 50 Y 30, M 20) } \\
\text { Oak 0\% } \\
\text { Ponderosa 0\% } \\
\text { Or Ash 10\%? }\end{array}$ & $\mathrm{n} / \mathrm{s}$ & $\mathrm{n} / \mathrm{s}$ & $\mathrm{n} / \mathrm{s}$ \\
\hline & $\begin{array}{l}\text { Structural diversity of } \\
\text { vegetation }\end{array}$ & $\begin{array}{l}\text { most canopy and } \\
\text { also well defined } \\
\text { multi }\end{array}$ & 27 & well defined multi & 27 & 0 & $0 \%$ \\
\hline & Shrub \% & $(50)-75$ & 24 & 100 & 24 & 0 & $0 \%$ \\
\hline & Frag/contig & contig & 3 & contig & 3 & 0 & $0 \%$ \\
\hline & $\begin{array}{l}\text { Native shrub layer } \\
\text { percent cover }\end{array}$ & $\begin{array}{l}50-75 \% \\
\text { vine maple, native } \\
\text { rose, indian plum, } \\
\text { oregon grape, } \\
\text { salmonberry, } \\
\text { thimbleberry, } \\
\text { elderberry, } \\
\text { huckleberry }\end{array}$ & & $\begin{array}{l}75-100 \% \\
\text { vine maple, salmon } \\
\text { berry }\end{array}$ & 3 & 0 & $0 \%$ \\
\hline & $\begin{array}{l}\text { Percent non-native } \\
\text { vegetation }\end{array}$ & $\begin{array}{l}\text { (5)-25\% } \\
\text { blackberry, english } \\
\text { ivy }\end{array}$ & & $0-5$ & 3 & 0 & $0 \%$ \\
\hline & Wetland \% & 0 & & 0 & 1 & 0 & $0 \%$ \\
\hline & Frag/contig & no & $\mathrm{n} / \mathrm{s}$ & no & $\mathrm{n} / \mathrm{s}$ & $\mathrm{n} / \mathrm{s}$ & $\mathrm{n} / \mathrm{s}$ \\
\hline & $\begin{array}{l}\text { Top 1-2 dominant } \\
\text { herbaceous species }\end{array}$ & $\begin{array}{l}\text { combo part sun } \\
\text { sword fern, } \\
\text { duckfoot, mostly } \\
\text { shade areas had } \\
\text { dense patch of } \\
\text { maidenhair fern, } \\
\text { oregon grape, moss } \\
\text { and lichen }\end{array}$ & & $\begin{array}{l}\text { combo part sun } \\
\text { sword fern, lady } \\
\text { fern, duckfoot, } \\
\text { stinky bob, } \\
\text { waterleaf, vanilla } \\
\text { leaf, enchanters } \\
\text { nightshade? }\end{array}$ & 24 & 0 & $0 \%$ \\
\hline Vegetation & $\begin{array}{l}\text { Maximum ground cover } \\
\text { gap (no veg) in } \\
\text { theoretical direction of } \\
\text { travel \& type (bare } \\
\text { ground, water, } \\
\text { developed) }\end{array}$ & 0 & 3 & 0 & 3 & 0 & $0 \%$ \\
\hline
\end{tabular}




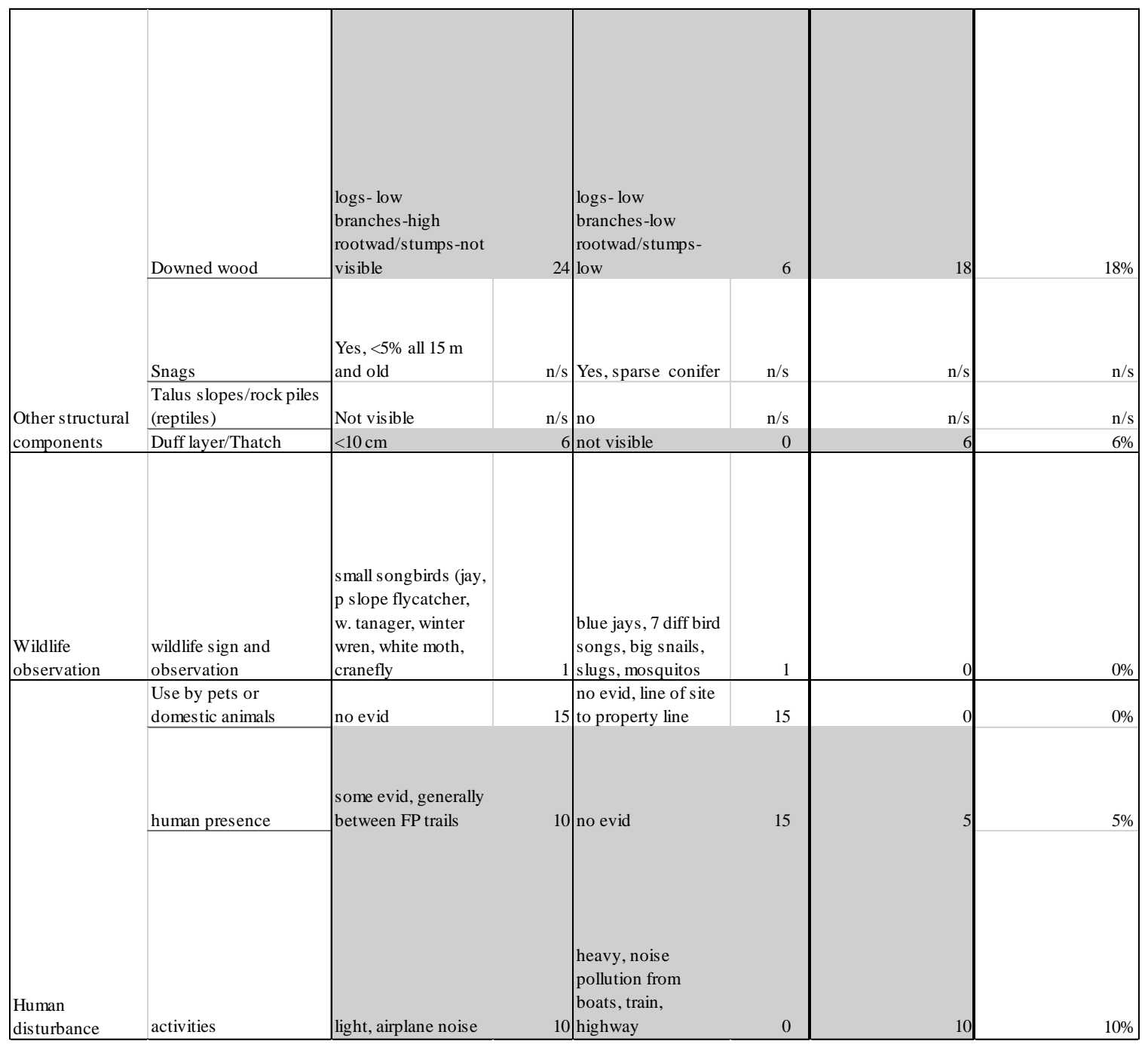


C.4 Oregon State Habitat Map Reclassification (PSU-INR 2018)

\section{Environments}

Extent 539228.1438 5033312.1595 547161.11625038869.6818

Cell Size $5 \mathrm{~m}$ (converted from $30 \mathrm{~m}$ )

Mask gresham study area extent

Parameters

Input raster StatewideHabitatMap.img

Reclass field Habitat

Predicted Core Terrestrial Habitat Types (Assigned value = 1)

Marshes, Bogs and Emergent Wetlands

Early Shrub-Tree

Interior Lowland and Foothill Riparian

Lowland Woody Wetlands and Swamps

Mixed Hardwood - Conifer young

Mixed Hardwood - Conifer medium

Mixed Hardwood - Conifer mature

Mixed Hardwood - Conifer old-growth

Mixed Conifer (White or Douglas Fir/Pine) young

Mixed Conifer (White or Douglas Fir/Pine) mature

Mixed Conifer (White or Douglas Fir/Pine) medium

Mixed Conifer (White or Douglas Fir/Pine) old-growth

Douglas Fir - Western Hemlock young

Douglas Fir - Western Hemlock medium

Douglas Fir - Western Hemlock old-growth

Douglas Fir - Western Hemlock mature

Mixed Oak - Conifer old-growth

Mixed Oak - Conifer young to medium

Mixed Oak - Conifer mature

Oak 


\section{Appendix D: \\ Forest Park Radio-telemetry Data}

\section{D.1 Summary}

\section{Monitoring Movement of the Northern Red-Legged Frog}

The Northern Red-legged Frog (Rana aurora) is listed as an at-risk, conservation strategy species in Oregon (Oregon Department of Fish and Wildlife 2016). It also lives in Washington and California. Efforts have been made to study how this species and its close relatives may be indicators for habitat fragmentation, climate resiliency, ecological health, and disease vectors. There are still questions on how land use, habitat availability and aquatic-terrestrial fragmentation affect amphibian mobility and chances for survival, especially in developed or urbanizing places (Hayes et al. 2008). The availability and connectivity of upland terrestrial habitat has been identified as a major conservation gap across managed environments in the Pacific Northwest (Grand et al. 2017). There is great interest in determining if there is preferential selection for closer, smaller forested patches in urban areas or whether distance to forest in combination with percent impervious surfaces contributes to R. aurora occupancy of habitat patches (Guderyahn, Smithers, and Mims 2016). There is a need to closely monitor regional populations and apply connectivity tools to understand how habitat availability and barrier mitigation affects local extinction risks.

Adult frogs' movement and mass migrations are most visible during winter breeding between November and February in the Portland Metropolitan area. Exact timing of active movement depends on weather conditions, nighttime temperatures, 
drought conditions and precipitation or moisture (Schuett-Hames 2004; Chan-McLeod and Moy 2007). Rana aurora are found in both ephemeral and permanent waters. At night, the females attach grapefruit-sized egg masses to submerged vegetation in shallow slow moving water (Licht 1969). Egg mass surveying and monitoring for aquatic breeding amphibians is conducted annually across the Portland Metropolitan area which provides rich occupancy and occurrence data. Additionally, studies in urbanizing areas like the Willamette Valley have no shown direct associations between invasive bullfrog predation influencing aquatic-habitat occupancy by $R$. aurora (Holzer 2014, Rowe et al. 2019). However, juvenile to adult terrestrial movement and habitat needs have not been extensively studied in the urbanizing region.

For the first time in 2018 and 2019, R. aurora were tracked in an intact, forested environment at the largest urban park in the region, Forest Park. Forest Park is considered a biodiverse anchor habitat for wildlife and native vegetation protected under conservation initiatives (City of Portland- Forest Park Desired Future Condition 2011, Forest Park Conservancy and Forest Park Alliance 2013, City of Portland- 2035 Comprehensive Plan 2018). Field-collected data provides baseline information on habitat quality, and functional connectivity requirements. Species-specific measurements for habitat quality and connectivity in urban areas cannot depend on GIS-based connectivity models unless these models are validated with movement responses of $R$. aurora. By tracking $R$. aurora we can consider how movement behaviors and migration distances are influenced by habitat quality and permeability using species specific scoring systems and standardizing field survey units (i.e. 500 x500 meter habitat connectivity zones). For 
instance, if we know frogs move greater than 500 meters across connected survey zones, then we can compare habitat quality, measure habitat size, and determine minimum distance between habitat patches within a standardized map unit to inform connectivity models.

Between March-May in 2018 and 2019, frogs were captured in coordination with the Harborton Frog Shuttle. As part of this Shuttle program, volunteers transport $R$. aurora annually between their wetlands and forested habitat. Based on transmitter weight requirements and the frog's physical health condition at recapture (i.e. transmitter is less than $5-10 \%$ of frog body weight, no preexisting injuries, skin lacerations, significant weight loss) we attached a waist belt transmitter to frogs in accordance to IACUCapproved safe handling procedures (Rathbun and Murphey 1996; Burow et al. 2012). Once fitted with Holohil BD-2 transmitters the individuals were tracked up to one month along a three-month period between March and May. Although continuous tracking for all captured frogs was not guaranteed due to predation, weather, waist belt slippage, or battery failure of the transmitter. During this study telemetry method accuracy was not evaluated, and triangulation data were discarded due to bouncing signals. Although transmitters can emit a signal in humid forests with vegetation, receiver antennas may not able to capture signals if the frogs are located underwater. Topography and canopy density may also obstruct signal strength. Similar radio-telemetry research has captured transmitter signals from 100-300 meters away in the field and at a maximum of up to 450-650 meters away without obstruction (Rathbun and Murphey 1996; Bull 2000; Burow et al. 2012). 
We mapped movement paths based on straight line distances between recapture locations where the individual frog was sighted and recaptured to assess health conditions. We captured 15 frogs in 2018, and 11 frogs in 2019. Due to the low sample size and limited tracking duration of frogs, we were unable to determine migration endpoints, although one frog in 2018 travelled at least 739 meters up steep upland forests and across a blackberry-filled powerline gap within 33 days after release. In 2019, the maximum straight-line distance traveled by an individual moving frog was approximately 300 meters with average weekly movements of 60.62 meters/week across all tracked frogs (range approximately 26-99 meters/week). These movement rates exclude movement prior to waist belt attachment, slipped waist belt events (i.e. prior to recapture), and no movement days between health checks.

We tracked frogs twice a week but tracked fewer individuals than similar radio telemetry studies, where on average 39 individuals per site were tracked and movement was compared across more than one site (Matthews and Pope 1999; Bulger, Scott, and Seymour 2003; Watson, McAllister, and Pierce 2003; McAllister et al. 2004; Fellers and Kleeman 2007; Tatarian 2008). However, the distance of travel we recorded in Forest Park was within the range of estimations from similar radio-tracking studies in the Puget Sound, Washington, which tracked frogs up to 500 meters between one to two months in peri-urban environments, and frogs were capable of moving even further (Schuett-Hames 2004; Hayes, Rombough, and Hayes 2007; Hayes et al. 2008; Grand et al. 2017).

We assessed habitat characteristics and quality using the Metro Regional Connectivity Toolkit habitat scorecard in 2019. The results showed variation in terms of 
tree canopy composition, and level of fragmentation depending on whether the location was along riparian areas or upland slopes but agreed with literature review of general habitat requirements such as structural vegetation diversity, ground cover, and moisture (Rabinowe et al. 2002; Schuett-Hames 2004; Hayes et al. 2008; Grand et al. 2017). It is still unclear whether the duration of time from release, seasonal weather conditions, local topography, distance from aquatic habitat, and forest patch size or quality influenced the dispersal of frogs in Forest Park. Nevertheless, our somewhat limited results fall within the range of monitoring studies and likely represent the probable movement capabilities of this species in the Portland region in terms of connectivity between aquatic-terrestrial habitat. We also did not consider forest management practices, history, or seasonal variation in vegetative cover in Forest Park. These results require a comparative tracking study for urban frog populations that are faced with limited, low quality habitat or are influenced by management activity. Tracking $R$. aurora at urban sites will require updated protocols, reliable capture methods, and a large sample size of migrating frogs.

\section{References:}

Bulger, J. B., N. J. Scott, and R. B. Seymour. 2003. Terrestrial activity and conservation of adult California red-legged frogs Rana aurora draytonii in coastal forests and grasslands. Biological Conservation 110 (1):85-95.

Bull, E. L. 2000. Comparison of two radio transmitter attachments on anurans. Herpetological Review 31:26-28.

Burow, A. L., A. L. Herrick, A. C. Geffre, and P. E. Bartelt. 2012. A fully adjustable transmitter belt for Ranids and Bufonids. Herpetological Review 43 (1):66-68.

City of Portland, Bureau of Environmental Planning 2018. 2035 Comprehensive Plan. Last Accessed 18 November 2019 at https://www.portlandoregon.gov/bps/2035-comp-plan.pdf 
City of Portland, Portland Parks and Recreation

2011. Forest Park Desired Future Condition. Last Accessed 18 November 2019 at https://www.portlandoregon.gov/parks/article/335638

Fellers, G. M., and P. M. Kleeman. 2007. California Red-Legged Frog (Rana draytonii) Movement and Habitat Use: Implications for Conservation. Journal of Herpetology 41 (2):276-286.

Grand, L., M. Hayes, K. Vogt, D. Vogt, P. Yarnold, K. Richter, C. Anderson, E. Ostergaard, and J. Wilhelm. 2017. Identification of habitat controls on northern redlegged frog populations: implications for habitat conservation on an urbanizing landscape in the Pacific Northwest. Ecological Processes 6 (1):1-13.

Forest Park Conservancy and Forest Park Alliance. 2013. Greater Forest Park Conservation Initiative. R. Myers, principal author. Last Accessed 18 November 2019 at www.forestparkconservancy.org

Guderyahn, L. B., A. P. Smithers, and M. C. Mims. 2016. Assessing habitat requirements of pond-breeding amphibians in a highly urbanized landscape: implications for management. Urban Ecosystems 19 (4):1801-1821.

Hayes, M. P., C. J. Rombough, and C. B. Hayes. 2007. Natural History: Rana aurora (Northern Red-legged Frog), movement. Herpetological Review 38:192-193.

Hayes, M. P., T. Quinn, K. O. Richter, J. P. Schuett-Hames, and J. T. Serra Shean. 2008. Maintaining Lentic-breeding Amphibians in Urbanizing Landscapes: The Case Study of the Northern Red-legged Frog (Rana aurora). Herpetological Conservation 3.

Licht, L. E. 1969. Comparative breeding behavior of the red-legged frog (Rana aurora aurora) and the western spotted frog (Rana pretiosa pretiosa) in southwestern British Columbia. Canadian Journal of Zoology 47 (6):1287-1299.

Matthews, K. R., and K. L. Pope. 1999. A Telemetric Study of the Movement Patterns and Habitat Use of Rana muscosa, the Mountain Yellow-Legged Frog, in a HighElevation Basin in Kings Canyon National Park, California. Journal of Herpetology 33 (4):615-624.

McAllister, K. R., J. W. Watson, K. Risenhoover, and T. McBride. 2004. Marking and Radiotelemetry of Oregon Spotted Frogs (Rana pretiosa) ed. M. J. Adams. Northwestern Naturalist 85 (1):20-25.

Oregon Department of Fish and Wildlife Oregon Conservation Strategy. 2016. Last Accessed 20 November 2019 at http://oregonconservationstrategy.org/strategyspecies/northern-red-legged-frog/ 
Rabinowe, J. H., J. T. Serra, M. P. Hayes, and T. Quinn. 2002. Natural history notes: Rana aurora aurora (northern red-legged frog). Herpetological Review 33:128.

Rathbun, G. B., and T. G. Murphey. 1996. Evaluation of a Radio-belt for Ranid Frogs. Herpetological Review 27 (4).

Rowe, J. C., A. Duarte, C. A. Pearl, B. McCreary, S. K. Galvan, J. T. Peterson, and M. J. Adams. 2019. Disentangling effects of invasive species and habitat while accounting for observer error in a long-term amphibian study. Ecosphere 10 (4).

Schuett-Hames, J. 2004. Northern Red-Legged Frog (Rana aurora aurora) Terrestrial Habitat Use in the Puget Lowlands of Washington. Last Accessed 31 August 2019 at http://archives.evergreen.edu/masterstheses/Accession86-10MES/Schuett-HJMESthesis2004.pdf

Tatarian, P. J. 2008. Movement Patterns of the California Red-Legged Frogs (Rana draytonii) in an Inland California Environment. Herpetological Conservation and Biology 3 (2):155-169.

Watson, J. W., K. R. McAllister, and D. J. Pierce. 2003. Home Ranges, Movements, and Habitat Selection of Oregon Spotted Frogs (Rana pretiosa). Journal of Herpetology 37 (2):292-300. 


\section{D.2 Blank Radio-telemetry and Health Checks Survey Sheets}

\section{Initial Condition/Measurements (release, Day 0)}

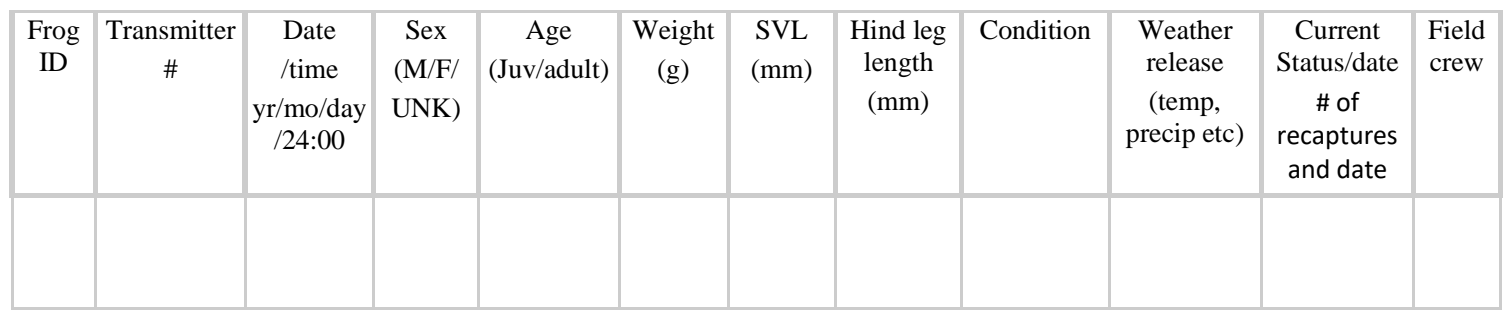

Updates (relocation/recapture and health condition)

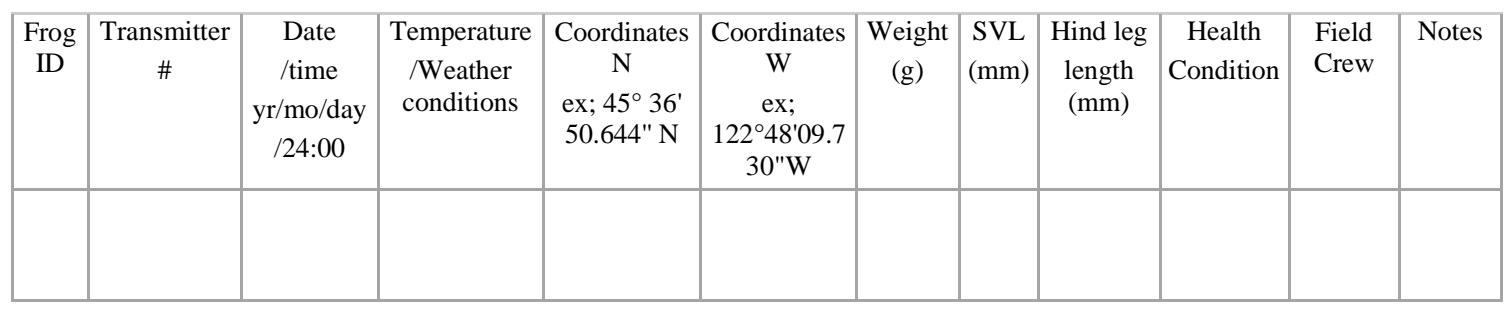

\section{Approximate Location data (radio-telemetry approximations/triangulation)}

\begin{tabular}{|c|c|c|c|c|c|c|c|c|c|c|c|}
\hline $\begin{array}{c}\text { Frog } \\
\text { ID }\end{array}$ & $\begin{array}{c}\text { Transmitter } \\
\#\end{array}$ & $\begin{array}{l}\text { Date/time } \\
\text { yr/mo/day/ } \\
24: 00\end{array}$ & $\begin{array}{c}\text { Field } \\
\text { Person } \\
1\end{array}$ & $\begin{array}{c}\text { Coordinate } \\
\mathrm{N} \\
\text { (survey pt } \\
1 \text { ) } \\
\text { ex; } 45^{\circ} 36^{\prime} \\
50.644^{\prime \prime} \mathrm{N}\end{array}$ & $\begin{array}{c}\text { Coordinate } \\
\text { W } \\
\text { (survey pt } \\
1 \text { ) } \\
\text { ex; } \\
122^{\circ} 48^{\prime} 09.7 \\
30^{\prime \prime} \mathrm{W}\end{array}$ & $\begin{array}{l}\text { Azimuth } \\
\text { (1) } \\
\text { (true } \\
\text { north } \\
\text { ON) }\end{array}$ & $\begin{array}{c}\text { Field } \\
\text { Person } \\
2\end{array}$ & $\begin{array}{c}\text { Coordinate } \\
\mathrm{N} \\
\text { (survey pt } \\
2 \text { ) } \\
\mathrm{ex} ; 45^{\circ} 36^{\prime} \\
50.644^{\prime \prime} \mathrm{N}\end{array}$ & $\begin{array}{c}\text { Coordinate } \\
\text { W } \\
\text { (survey pt } \\
2 \text { ) } \\
\text { ex; } \\
122^{\circ} 48^{\prime} 09 . \\
730^{\prime \prime} \mathrm{W}\end{array}$ & $\begin{array}{l}\text { Azimuth } \\
\text { (2) } \\
\text { (true } \\
\text { north } \\
\text { ON) }\end{array}$ & Notes \\
\hline & & & & & & & & & & & \\
\hline
\end{tabular}




\section{D.3 Radio-telemetry Detailed Procedure}

1. Record radio-telemetry user position

- Designate field team 1 and 2

-Record on data sheet provided with pencil and initial name.

-Prior to taking frog positions, coordinate which frog \# you are locating with partner

- Record transmitter \# (frog ID \#)

- Record Date/time (ex; yr/mo/day/24:00)

- Record field person initials

- Turn on GNSS unit

- Walk to the nearest designated user position location and ensure you can retrieve coordinate accuracy. $5+$ satellites, $<10 \mathrm{~m}$ accuracy, and 50 points are needed to record accurate coordinates

-Record a pair of coordinate locations each time 2-6 telemetry azimuth angles are taken, and indicate on data sheet if telemetry point is taken at a new location

- Record N and W (latitude and longitude) coordinates to 3 decimal places using GPS unit (ex; DMS 45³6' 49.875" N , 122 48'08.110"W or use DD mobile 45.613854, 122.802253)

2. Locate frog's transmitter signal and Record GNSS location

-Turn on receiver and ensure antennae is connected, batteries are more than half full

-Holding the antennae with flat plane pointed downward (with the tip pointed out) and at a comfortable and consistent level

- To start, rotate the antenna direction 360 degrees and at high gain.

- Use strength of the sound on the receiver to identify best location.

- Once you have the general direction, decrease the gain until it's about as low it can be while still allowing detection then hone in on the location.

-A short clear chirp is the BEST sound that indicates you are within 10 meters, and correct direction

-Do not proceed closer than 10 meters if frog is visible

3. Record azimuth angle

- Use compass or phone app (TRUE NORTH ON) to record azimuth angle (degrees).

- If there isn't a clear direction that has the highest volume, with the gain still as low as possible, record what you are pretty sure is the loudest and also from left to right the range that you can hear the signal. If using a range, record these data on the datasheet (all in the azimuth column) as: 316 (L: 300, R: 337).

Additional Procedures

*If the signal seems to be coming from all around you or from two opposing directions, this could be a conflict with the topography, or you may be too close/too far from the frog. Flag down a team leader to coordinate a new location to take telemetry at. You can also try moving to a different location, recording that location if signal strength and direction is clear. 


\section{D.4 Radio-telemetry Movement Map (Forest Park, Oregon 2019)}

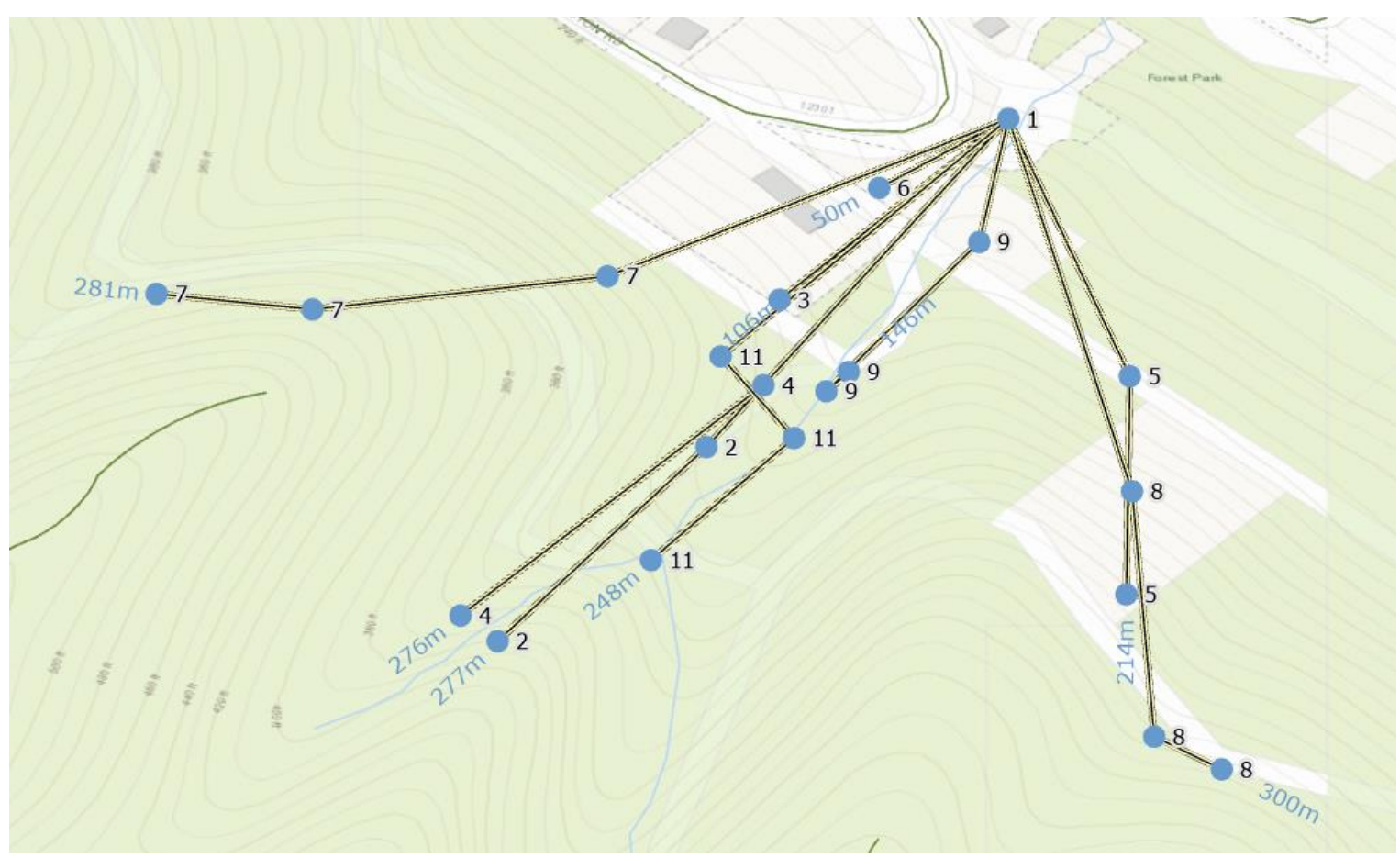

Northern Red-legged frog total average distance traveled, straight line approximations up to $300 \mathrm{~m}$ (tracked at 274 meters) from release site. Three release events occurred between March 22- April 3, 2019. Frog ID Label 1 is an aggregation of multiple frog's release sites and recovered transmitters ( $<10$ meters from release site) at the edge of Forest Park. The release site is alongside an intermittent stream (blue), private residences (dark gray), and managed private lands (light gray). Locations at the end of these approximate movement paths are a combination of slipped waist belt recovery sites and sites where waist belt removal was determined at health checks. Underground streams/seeps were observed along Frog ID label 5 and 8 but is not represented in regional stream data or on this map. 
D.5 Movement Results (Forest Park, Oregon 2018, 2019)

\begin{tabular}{|c|c|c|}
\hline $\begin{array}{l}\text { *Maximum total distance fr } \\
\text { wetlands } \sim 300 \mathrm{~m} \text { from relea } \\
* * \text { outlier for } 2018 \text { Frog ID\# } \\
* * * \text { Telemetry approximatio }\end{array}$ & $\begin{array}{l}\text { release site at start date. Excludes dis } \\
\text { site. } \\
\text { ? } \\
\text { mitted from further analysis due to er }\end{array}$ & $\begin{array}{l}\text { nce from breeding pond PG\&E } \\
\text { r (user and topography) }\end{array}$ \\
\hline Movement Data Results & & \\
\hline & 2019 & 2018 \\
\hline $\begin{array}{l}\text { Number of Individuals } \\
\text { Tracked }\end{array}$ & $\begin{array}{l}\text { Total } n=11 \\
\text { Slipped Waist belts } n=2(18 \%) \\
\text { Potential predation } n=3(27 \%) \\
\text { Recovery } n=11(100 \%)\end{array}$ & $\begin{array}{l}\text { Total } \mathrm{n}=15 \\
---- \\
\text { Slipped Waist belts } \mathrm{n}=12(80 \%) \\
\text { Potential predation } \mathrm{n}=1(6 \%) \\
\text { Recovery } \mathrm{n}=14(93 \%)\end{array}$ \\
\hline $\begin{array}{l}\text { Average } \\
\text { Weight } \\
\text { / Snout-vent length (SVL) }\end{array}$ & $\begin{array}{l}41.54 \mathrm{~g}(35-49 \mathrm{~g}) \\
/ 77.95 \mathrm{~cm}(69.3-95 \mathrm{~cm}) \\
\text { weight-SVL Ratio: } 1: 1.8\end{array}$ & $\begin{array}{l}40.06 \mathrm{~g}(30-49 \mathrm{~g}) \\
/ 77.26 \mathrm{~cm}(68-85 \mathrm{~cm}) \\
\text { weight-SVL ratio: } 1: 1.19\end{array}$ \\
\hline Number of Male/Female & $\begin{array}{l}\text { Not confirmed } \\
\text { Female }=8 \\
\text { Male }=3 \text { (unconfirmed) }\end{array}$ & $\begin{array}{l}\text { Not confirmed } \\
\text { Female } n=14 \\
\text { Male } n=1 \text { (unconfirmed) }\end{array}$ \\
\hline Tracking Dates & $\begin{array}{ll}03 / 22 / 19-05 / 17 / 19 & \\
\text { Start Date } 03 / 22 / 19 & (n=4) \\
\text { Start Date } 03 / 28 / 19 & (n=1) \\
\text { Start Date } 04 / 02 / 19 & (n=6)\end{array}$ & $\begin{array}{l}03 / 17 / 18-04 / 23 / 18 \\
\text { Start Date 03/13/18 }(n=4) \\
\text { Start Date 03/22/18 }(n=4) \\
\text { Start Date 04/05/18 }(n=7)\end{array}$ \\
\hline Recapture & $\begin{array}{l}\text { Maximum x3 }(n=3) \\
X 2(n=4) \\
X 1(n=1) \\
\text { None }(n=3)\end{array}$ & $\begin{array}{l}\text { Maximum } x 3(n=1) \\
\text { X2 }(n=0) \\
\text { X1 }(n=3) \\
\text { None }(n=11)\end{array}$ \\
\hline Days Tracked & $\begin{array}{l}\text { Season Total }=67 \text { days } \\
\text { Individual Min }=2 \text { days } \\
\text { Individual Max }=28 \text { days }\end{array}$ & $\begin{array}{l}\text { Season Total }=38 \text { days } \\
\text { Individual Min= } 3 \text { days } \\
\text { Individual Max= } 33 \text { days }\end{array}$ \\
\hline $\begin{array}{l}\text { Average Weekly } \\
\text { Movement }\end{array}$ & $\begin{array}{l}\text { Average Weekly movement } \\
\qquad=60.62 \mathrm{~m} / \mathrm{wk} \\
\text { Median } 46.62 \mathrm{~m} / \mathrm{wk} \\
\text { Range approx } 26.44 \text { to } 99.81 \mathrm{~m} / \mathrm{wk} \\
\text { No movement days }(\mathrm{n}=2)\end{array}$ & Insufficient Data \\
\hline
\end{tabular}




\begin{tabular}{|c|c|c|}
\hline $\begin{array}{l}\text { Maximum Total Distance } \\
\text { from release }(+/-50 \mathrm{~m})^{*} \\
\text { Minimum Total Distance } \\
(+/-50 \mathrm{~m}) \\
\text { Additional } \sim 300 \mathrm{~m} \text { to } \\
\text { wetlands not included }\end{array}$ & $\begin{array}{l}274.61 \\
10.8 \mathrm{~m}\end{array}$ & $\begin{array}{l}739 \text { (outlier, from release } \\
\text { point)** } \\
\text { Unknown }(<30 \mathrm{~m}) \text { ? }\end{array}$ \\
\hline $\begin{array}{l}\text { Direction of Travel } \\
\text { (degrees) }\end{array}$ & $\begin{array}{l}\text { avg } 196.9 \\
\text { median } 214 \\
\text { Range } 122-277 \text { SE to SW } \\
\text { *one instance of } 41 \text { deg, going back } \\
\text { toward initial release site }\end{array}$ & Insufficient data \\
\hline $\begin{array}{l}\text { Known Location Nearest } \\
\text { Neighbor Distance } \\
\text { NND }\end{array}$ & $\begin{array}{lc}\text { Average } & 38.72 \\
\text { Minimum } & 10.88 \\
\text { Maximum } & 52.28\end{array}$ & $\begin{array}{lc}\text { Average } & 29.03 \\
\text { Minimum } & 02.23 \\
\text { Maximum } & 248.29 * *\end{array}$ \\
\hline $\begin{array}{l}\text { Telemetry Approximation } \\
\text { Nearest Neighbor } \\
\text { Distance*** } \\
\text { NND }\end{array}$ & $\begin{array}{l}\text { Average } \\
\text { Minimum } \\
\text { Maximum }\end{array}$ & $\begin{array}{lc}\text { Average } & 21.15 \\
\text { Minimum } & 00.80 \\
\text { Maximum } & 202.66^{* *}\end{array}$ \\
\hline
\end{tabular}

